\title{
Continuing pain education : the impact on nursing practice
}

Citation for published version (APA):

Francke, A. L. (1996). Continuing pain education : the impact on nursing practice. [Doctoral Thesis, Maastricht University]. Rijksuniversiteit Limburg. https://doi.org/10.26481/dis.19960613af

Document status and date:

Published: 01/01/1996

DOI:

10.26481/dis.19960613af

Document Version:

Publisher's PDF, also known as Version of record

\section{Please check the document version of this publication:}

- A submitted manuscript is the version of the article upon submission and before peer-review. There can be important differences between the submitted version and the official published version of record.

People interested in the research are advised to contact the author for the final version of the publication, or visit the DOI to the publisher's website.

- The final author version and the galley proof are versions of the publication after peer review.

- The final published version features the final layout of the paper including the volume, issue and page numbers.

Link to publication

\footnotetext{
General rights rights.

- You may freely distribute the URL identifying the publication in the public portal. please follow below link for the End User Agreement:

www.umlib.nl/taverne-license

Take down policy

If you believe that this document breaches copyright please contact us at:

repository@maastrichtuniversity.nl

providing details and we will investigate your claim.
}

Copyright and moral rights for the publications made accessible in the public portal are retained by the authors and/or other copyright owners and it is a condition of accessing publications that users recognise and abide by the legal requirements associated with these

- Users may download and print one copy of any publication from the public portal for the purpose of private study or research.

- You may not further distribute the material or use it for any profit-making activity or commercial gain

If the publication is distributed under the terms of Article $25 \mathrm{fa}$ of the Dutch Copyright Act, indicated by the "Taverne" license above, 


\section{CONTINUING PAIN EDUCATION:}

\section{THE IMPACT ON NURSING PRACTICE}





\section{CONTINUING PAIN EDUCATION: THE IMPACT ON NURSING PRACTICE}

\section{PROEFSCHRIFT}

ter verkrijging van de graad van doctor aan de Rijksuniversiteit Limburg te Maastricht, op gezag van de Rector Magnificus, Prof. mr. M.J. Cohen, volgens het besluit van het College van Dekanen, in het openbaar te verdedigen

op donderdag 13 juni 1996 om 16.00 uur

door

Anneke L. Francke 


\section{Promotores:}

Prof. dr. M.J. de Vries (Erasmus Universiteit Rotterdam)

Prof. dr. H. Huijer Abu-Saad

Prof. dr. M. Grypdonck (Universiteit Utrecht)

\section{Co-promotor:}

Dr. B. Garssen (Helen Dowling Instituut, Rotterdam)

\section{Beoordelingscommissie:}

Prof. dr. J. van der Zee (voorzitter)

Prof. dr. M.S.H. Duijnstee (Universiteit Utrecht)

Prof. dr. J.A. Knottnerus

Prof. dr. L.J. Menges (Vrije Universiteit Amsterdam)

Prof. mr. F.C.B. Van Wijmen

Francke, A.L.

Continuing pain education: the impact on nursing practice.

ISBN: 90-9009525-x

Trefw.: pain, nursing, education

Ontwerp omslag: Joop de Kler

The research described in this dissertation was carried out at the Helen Dowling Institute for Biopsychosucial Medicine, Rotterdam, the Netherlands.

The financial support by the Dutch Ministry of Health, the Prevention Fund, Stichting ter Bevordering van Volkskracht and Johan Vermey Stichting is gratefully acknowledged. 


\section{CONTENTS}

Chapter 1 Introduction 7

History of CE 9

Need for continuing education on pain 10

Impact of $\mathrm{CE} / 1$

Content of the dissertation 12

References 13

Chapter 2 Continuing pain education in nursing; a literature review 15

Summary 17

Introduction 17

Pain CE programs 17

Research methods 21

Effects 28

Discussion 28

References 29

Chapter 3 Qualitative needs assessment prior to a continuing education program on pain assessment and management 33

Summary 35

Introduction 35

Participant observations 36

Nurse interviews 37

Patient interviews $4 I$

Translation of the findings into the CE program 44

Discussion 44

References 45

Chapter 4 Confluent Education; the educational method of the program 49

Summary 51

Introduction 51

Characteristics of Confluent Education 51

Confluent Education in practice 55

Closing remarks 58

References 59

Chapter 5 Pilot study on the effects of the program 61

Summary 63

Introduction 63

Pilot program 63

Evaluation of the pilot program 64

Effects of the pilot program 66

Closing remarks 67

References 68

Chapter 6 Effects of the program on nurses' pain assessments 69

Summary 71

Introduction 71

Methods 72

Results 77

Discussion 78

References 79 
Chapter 7 Effects of the program on nurses' psychosocial, physical and relaxation interventions 81

Summary 83

Introduction 83

Methods 84

Results 88

Discussion 90

References 91

Chapter 8 Effects of the program on nurses' pharmacological

pain management 95

Summary 97

Introduction 97

Methods 97

Results 102

Discussion 108

References 109

Chapter 9 Effects of the program on patients 111

Summary 113

Introduction 113

Methods 114

Results 116

Discussion 120

References 121

Chapter 10 Nurses' perceptions of factors influencing the use of the program 123

Summary 125

Introduction 125

Methods 126

Results 128

Discussion 134

References 135

Chapter 11 General discussion 137

Summary 139

Results: overview and reflections 139

Methodological reflections 144

Recommendations 147

References 150

Summary 153

Samenvatting 159

Dankwoord 165

Curriculum vitae 169

Appendix I. Description of the content of the program 173 
CHAPTER 1

Introduction 


\section{Introduction}

"Let us never consider ourselves as finished nurses. We must learn all our lives!" (Florence Nightingale)

Nurses are becoming more and more involved in a process of professionalization. The main characteristic of this process is nurses' endeavour to act more autonomously on the basis of scientific and professional knowledge (Evers, 1990; Grypdonck, 1991). Presentday nurses are also confronted with significant societal trends, such as ageing of the population and an increase in prosperity. These trends have resulted in nurses encountering certain diseases (e.g. cancer) more frequently and in higher requirements for cure and care. Furthermore, nurses are confronted with rapid advances in pharmacology, technology and the social sciences, all of which require adaptation of knowledge, skills and attitudes (WaddelI, 1990; Van Ginkel \& Kerkstra, 1994; Nolan et al., 1995).

As a result of the foregoing, a wave of continuing education (CE) is sweeping through nursing. In accordance with the widely accepted definition of the American Nurses Association (1975), in this dissertation with CE is meant:

"Planned learning experiences beyond a basic nursing educational program designed to promote the development of knowledge, skills and attitudes for the enhancement of nursing practice, thus improving health care to the public".

Large numbers of nurses participate in various types of CE programs, such as staff development courses, conferences, workshops and training programs ${ }^{1}$ (TVZ-guide for education and training, 1994 and 1995). As indicated in the aforementioned definition, the ultimate aim of $\mathrm{CE}$ for nurses is to improve nursing practice and health care. For example, after a program on pain assessment and management, a nurse is expected to practice more adequate pain interventions, which may lead to more pain relief for patients. This dissertation aims to provide more insight as to whether continuing pain education actually has such a positive impact. The specific aim of this introductory chapter is to provide some general information on $\mathrm{CE}$ for nurses and on the content of the dissertation.

\section{History of CE}

Trends in North America. The professionalization process for nurses began in North America earlier than elsewhere. It is therefore not a coincidence that American nurses played a leading role in CE. Planned programs arrived on the scene in the USA as early as the first half of the 20th century. The Goldmark Report in 1923 and the Brown Report in 1948 indicated the need for educational interventions to improve nursing practice (cited from Wilk, 1986; Waddell, 1990). Several learning needs were identified in these reports which stimulated the development and implementation of CE programs.

In the second half of the century. North American professional organizations started to focus on quality assurance in CE. As a result, the Council on Continuing

'. Because the distinction between the types of CE programs is vague, the general term 'CE program' will be further used. However, it must be noted that advanced education concerning fundamental programs teading to registered nurse specialist positions is not discussed in this dissertation. 


\section{Chapter 1}

Education was established within the American Nurses Association in 1973. The Council developed quality standards and an accreditation system for CE which enabled nurses to identify and select programs that met established standards (Cooper, 1974).

The question of whether CE activities should be mandatory was an important issue in the 70's and 80's (Weiss-Farnan \& Willie, 1988). For many policy makers and instructors, making CE mandatory was a way to ensure that nurses keep up with changes in nursing practice (e.g. Dodge, 1980). However, opponents of mandatory CE questioned whether CE requirements could prevent professional obsolescence (e.g. Cooper, 1973). Opinions still vary, and today about $50 \%$ of the states in the USA require CE for recertification.

Trends in the Netherlands. Unfortunately, no historical documentation is available on nursing CE in the Netherlands. Therefore, it is difficult to say when planned CE programs were introduced in Dutch nursing practice. Recent documentation is scarce as well. However, in 1994 and 1995 the much-read journal 'Tijdschrift voor Ziekenverpleging' (Journal for Nursing) published overviews of Dutch nursing CE (TVZguide for education and training, 1994 and 1995). In addition, the research institute NIVEL published an overview of CE programs offered for Dutch district nurses (Van Ginkel \& Kerkstra, 1994). These publications list the hundreds of CE programs available nowadays on such subjects as pain, oncology and communication skills.

As in most other European countries, there is no mandatory nursing CE regulated by law in The Netherlands. In spite of this, institutions sometimes require their nurses to attend CE programs. An important development in this regard is the adoption of the BIG bill in 1993 (Beroepen in de Individuele Gezondheidszorg - Professions in Individual Health Care). BIG legislation provides rules for the registration of nurses and other health care professionals. In addition, the BIG defines activities that nurses can practice autonomously and those that they can only practice under the supervision of a physician. A direct consequence of BIG legislation is that demands can be made with respect to the quality of nursing care, for example by compelling nurses to participate in CE. As a result, many institutions offer their employees more or less required CE programs to fill gaps in (mainly technical and curative) knowledge and skills.

Contrary to the situation in the USA, no official quality standards or accreditation systems for nursing CE exist in Holland.

\section{Need for continuing education on pain}

Pain is one of the CE topics in which nurses are highly interested (Itano \& Miller, 1990; Jeffrey, 1994; Pritchard, 1988). Nurses' interest in CE on pain is probably related to the fact that, despite all the possibilities of modern health care, many patients still suffer from chronic or acute pain (e.g. Abbott et al., 1990: Carr, 1990; Juhl et al., 1993: Kuhn et al., 1990; Paice et al., 1991). For example, for $40 \%$ of the surgical patients interviewed by Kuhn et al. (1990), the postoperative period had been very painful. The average pain intensity experienced during the first 24 postsurgical hours was perceived as $60 \%$ of the maximum. Although the intensity lessened day by day, patients were reporting pain as late as the sixth postoperative day. The other studies referred to also established that large 


\section{Introduction}

groups of patients suffer from mild to severe pain. However, particularly severe pain has no useful function and may lead to a variety of psychological and physical complications (Bonica, 1987; Puntillo \& Weiss, 1994).

Nurses' specific interest in CE on pain may also be connected to deficiencies in initial nursing education. Although pain is increasingly recognized as a priority by both national and international agencies (e.g. APS, see Max, 1990; Gezondheidsraad, 1986; IASP, 1992; NVBP, 1993; ONS, see Spross et al., 1990; VWR/CBO, 1994), education on pain is still limited (Diekmann \& Wassem, 1991; Ferrell el al., 1993; Graffam, 1990; De Schepper, 1991). A recent study ${ }^{2}$ indicated that, on average, less than five contact hours are devoted to pain in Dutch higher initial nursing education (HBOV). In the light of these facts, it is understandable that many nurses have insufficient knowledge regarding methods to assess and alleviate pain and are eager to reduce their educational lacunas by means of CE (Itano \& Miller, 1990; Jeffrey, 1994; Pritchard, 1988).

\section{Impact of CE}

Determining whether $\mathrm{CE}$ is really effective has become increasingly necessary as a consequence of the expansion of CE programs and the increase in health care costs. This has resulted in a number of (mainly quasi-experimental) effect studies to investigate whether CE programs indeed affect nurse performance. Waddell (1990 and 1991) conducted a meta-analysis of 34 sudies on nursing CE programs. Waddell's analysis supported the hypothesis that $\mathrm{CE}$ has a positive impact on nurses' interventions in nursing practice. However, Waddell included publications on very different types of CE programs in her meta-analysis. Whether this hypothesis is also supported in relation to a particular type of CE. for instance CE on pain, remained unclear.

Since the ultimate aim of $\mathrm{CE}$ in nursing is improving nursing practice and public health care (American Nurses Association, 1975 and 1986), it would be logical to examine effects on both nurses and patients. In spite of this, little research has been carried out on the impact on patients of CE directed to nurses. A possible reason for this hiatus may be that involving patients in research has more ethical and practical consequences than involving only nurses.

Considering the current abundance of programs and the limitations of existing studies. further research into the effectiveness of $C E$ remains a major direction for the future. A main challenge is to examine whether CE for nurses not only affects nurses' outcomes, but also patients' outcomes. In the research project described in the dissertation this challenge was taken up with respect to $\mathrm{CE}$ on pain.

2. In this study, the author (A.L.F.) was involved as project leader. Research firdings will be presented in a report at the end of 1996. 


\section{Chapter 1}

\section{Content of the dissertation}

After this general introduction, the state of the art of research on continuing pain education for nurses is discussed in Chapter 2. On the basis of a critical review of the literature, reflections are made on characteristics of the programs, the methods used to evaluate the programs and the programs' impact.

The core part of the dissertation (Chapters 3-10) is based on a research project in which a $C E$ program on pain assessment and management was developed, implemented and evaluated (see Figure 1.1).

Figure 1.1. The research project and relevant chapters

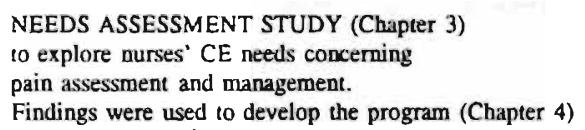

to test the program and the evaluation instruments

|

CONTROLLED INTERVENTION STUDY QUALITATIVE INTERVIEWS (Chapter 10)

to investigate effects of the program on nurses (Chapters 6-8)

and patients (Chapter 9) for gaining insight into factors influencing the effects of the program

First of all, Chapter 3 presents a needs assessment study carried out prior to the development of the CE program. The various research questions addressed in this chapter can be summarized as:

- What are nurses' CE needs with respect to pain assessment and management in surgical cancer patients?

Next, in Chapter 4, the educational method used in the program is discussed. Then, Chapter 5 presents a pilot study in which the program and the evaluation instruments were tested. The four subsequent chapters discuss the findings of a controlled intervention study which aim was to provide further insight into the effects of the program. Effects on pain assessments are discussed in Chapter 6, effects on psychosocial, physical and relaxation interventions in Chapter 7, effects on pharmacological pain management in Chapter 8, and effects on patients in Chapter 9. The various research questions addressed in the Chapters 5-9 can be summarized as follows: 
Does the CE program result in an improvement of nurses' outcomes related to pain assessment and management, and in an improvement of patients' outcomes related to pain?

Finally, Chapter 10 presents qualitative evaluation interviews and addresses the question:

- According to nurse participants, what factors affected the application of what had been learned in the $C E$ program positively or negatively?

Most of the chapters in this dissertation are based on articles published or submitted for publication in scientific journals. However, in order to improve the readability of the dissertation, strong overlaps between the original texts were deleted, and in each chapter references were made to relevant parts in other chapters.

\section{References}

Abbott FV, Gray-Donald K, Sewitch MJ. Johnston CC. Edgar L \& Jeans ME (1990). The prevalence of pain in hospitalized patients and resolution over six months. Pain, 50, 15-28.

Abramson, S (1984). Evaluation of continuing education in the health professions: the state of the art. Evaluation and the Health Professions 7, 1, 3-23.

American Nurses Association Council on Continuing Education. (ANA, 1975). Standard for continuing education in nursing. Kansas City, Missouri: American Nurses Association.

American Nurses Association Council on Continuing Education. (ANA, 1986). Manual for accreditation as an approver of conrinuing education in nursing. Kansas City, Missouri: American Nurses Association.

Bonica JJ (1987). Importance of effective pain control. Acta Anaesthesiologica Scandinavica, 85, 1-16.

Carr ECJ (1990). Post-operative pain: patients' expectations and experiences. Journal of Advanced Nursing 15. $89-100$.

Cooper SS (1973). Should contiuuing education be mandatory? (No). American Joumal of Nursing, 73, 442.

Cooper SS (1974). Why a council on continuing education? Joumal of Continuing Education in Nursing 5 , 3. 7-9.

Dodge G (1980). Legislators look askance at mandatory CE. AORN Joumal, 31, I080-1091.

Diekmann JM \& Wassem RA (1991). A survey of nursing students' knowledge of cancer pain control. Cancer Nursing 14, 6, 314-319.

Evers G (1990). Professionalisering van de verpleging: een analyse van beleidsmatige ontwikkelingen. Tijdschrift voor Ziekenverpleging, 13, 410-415.

Ferrell BR, McGuire DB \& Donovan MI (1993). Knowledge and beliefs regarding pain in a sample of nursing faculty. Joumal of Professional Nursing 9. 2, 79-88.

Gezondheidsraad (1986). Advier inzake pijnbehandeling. Den Hagg: Gezondheidsraad.

Ginkel M van \& Kerkstra A (1994). Bij- en nascholingraanbod voor de wijkverpleging in de zorg voor chronisch zieken. Utrecht: NIVEL.

Graffam $S$ (1990) Pain content in the curriculum: a survey. Nurse Educator 15, 20-23.

Grypdonck, M (1991). Professionalisering van de verpleegkundige zorg: mogelijkheden en grenzen. Verplecgkande, Nederlands-Vlaams Tijdschrift voor Verpleegkundigen S, 1. 28-35.

International Association for the Srudy of Pain (IASP/Ready LB \& Edwards WT, Eds., I992), Management of acute pain. A practical guide. Task Force on Acute Pain. Seatue: IASP Publications.

ltano J \& Miller CA (1990). Learning needs of Oncology Nursing Society members. Oncology Nurring Forum 17, 5, 697-703.

Jeffrey D (1994). Education in palliative care: a qualitative evaluation of the present state and the needs of general practitioners and cormmunity nurses. Europenn Journal of Cancer Care, 3, 67-74.

Juhl IU, Christensen BV, Bülow HH, Wilbek H, Dreijer NC \& Egelund B (1993). Postoperative pain relief, from the patients' and the murses' point of view. Acta Anaesthesiologica Scandinavica, 37, 404- 


\section{Chapter I}

409.

Kuhn S, Cooke K, Collins M. Jones MJ \& Mucklow JC (1990). Perceptions of pain relief after surgery. British Medical Joumal 300, 1687-1690.

Max M (1990). American Pain Society quality assurance standards for relief of acute and cancer pain. In MR Bond. JE Charlton \& Woolf CJ (Eds.). Proceedings of the VI World Congress on Pain (pp. 185-189). Amsterdam: Elsevier.

Nederlandse Vereniging ter Bestudering van Pijn (NVBP/Dingemans WA, Groemman NH, Van Kleef M \& Krijgsman MJ, Eds., 1993). Pijn en pijnbehandeling, een basaal onderwijscurriculum. Maastricht: Universitaire Pers.

Nolan M, Owens RG \& Nolan, J (1995). Continuing professional education: identifying the characteristics of an effective system. Joumal of Advanced Nursing 21, 551-560.

Paice JA, Mahon SM \& Faut-Callahan, M (1991). Factors associated with adequate pain control in hospitalized postsurgical patients diagnosed with cancer. Cancer Nursing 14, 6, 298-305.

Pritchard AP (1988). Management of pain and nursing attitudes. Cancer Nursing 11, 3, 203-209.

Puntillo K \& Weiss SJ (1994). Pain: its mediators and associated morbidity in critically ill cardiovascular surgical patients. Nursing Research 43, 1, 31-36.

Schepper AME de (1991). Leren over pijn en pijnbehandeling in basisverpleegkundige leerboeken. Een literatuuronderzoek. Unpublished master thesis. Maastricht, the Netherlands: State University Limburg.

Spross JA, McGuire DB \& Sclumitt RM (1990). Oncology Nursing Society position paper (Par II). Oncology Nursing Forum 17, 751-760.

TVZ-gids voor opleiding en training (TVZ-guide for education and training (1994 en 1995). Utrecht: De Tijdstroom.

Verpleegkundig Wetenschappelijke Raad/Centraal Begeleidingsorgaan voor de Intercollegiale Toetsing (VWR/CBO, 1994). Consensus Verpleegkunde bij Pijn. Utrecht: CBO.

Waddell DL (1990). The effects of continuing education on nursing practice: a meta-analysis. Dissertation University of Georgia. Michigan: UMI dissertation services.

Waddell DL (1991). The effects of continuing education on nursing practice: a meta-analysis. Joumal of Continuing Education in Nursing 22, 164-168.

Weiss-Farnan P \& Willie R (1988). Mandatory continuing education: the discussions a decade apart. Journal of Continuing Education in Nursing 19, 2, 73-75.

IVilk J (1986). From continuous education to continuous learning: moving toward accountability. Joumal of Continuing Education in Nursing 17, 1. 16-18. 
CHAPTER 2 Continuing pain education in nursing;

a literature review

This chapter is an adapted version of the article 'Continuing pain education in nursing; a literature review'.

Accepted for publication in the International Journal of Nursing Studies.

Authors: AL Francke, B Garssen \& H Huijer Abu-Saad. 


\title{
Continuing pain education in nursing;
}

\author{
a literature review
}

\section{Summary}

Sixteen studies on the effects of continuing pain education for nurses were reviewed. Most of the CE programs focused on aspects of pain, pain medication or pain assessment. Only four programs (Dalton et al., 1995; Ferrell et al., 1993; Meyerink et al., 1994; Sofaer, 1984) also paid attention to nonpharmacological nursing interventions. Randomized control groups, established measurement instruments and long term followup measurements, were rarely used in the effect evaluation of the programs. Effects reported on both nurses and patients were for the most part positive. Given the rather small number of studies and their methodological limitations, further research into the effectiveness of continuing pain education in nursing is indicated.

\section{Introduction}

Many nurses feel a need for CE with regard to the subject of pain (Ferrell et al., 1993; Itano \& Miller, 1990). This is not without reason; initial nursing education devotes limited attention to pain-related topics, and in practice pain is often insufficiently relieved (e.g. Abbott et al., 1990; Carr, 1990; Davis, 1991; Diekmann \& Wassem, 1991; Graffam, 1990; Paice et al., 1991).

Research on the effectiveness of pain programs is important because of the great need for CE on pain, Effect evaluation gives insight into whether the main aim of CE, improving nursing practice and health care, is achieved. Yet, only twenty intervention studies on the effects of pain CE programs for nurses were tracked down. The main sources for literature references were Med-Line, Psychlit and Eric databases (CD-ROM), the Journal of Continuing Education in Nursing, the Journal of Nursing Staff Development and a meta-analytic study by Waddell (1990). Strict methodological selection criteria were not employed because the amount of available literature was modest, and consequently both controlled and uncontrolled studies were included. Three of the twenty studies found (Dalglish, 1990; Glajchen et al., 1993; Struthers \& Jetfrey, 1993) were omitted in the review, because they lacked too much information relevant to the CE programs, research methods or programs' effects. One other program (Bookbinder et al., 1995) was omitted because this program was part of a very broad innovation (that also included formal implementation of pain standards, and introduction of clinical nurse specialists and multidisciplinary pain teams), making it less comparable to the other programs reviewed. The remaining sixteen studies (see Tables 2.1 and 2.2) are presented in this chapter.

\section{Pain CE programs}

Characteristics. Most of the programs reviewed paid attention to aspects of pain: e.g. cultural and psychological aspects, and pain theories and definitions. Pharmacological pain management and pain assessment were also included in many programs. As part of the latter, instruction was often given on pain measurement instruments such as pain rating scales or pain assessment questionnaires (see Table 2.1). 
Table 2.1. Characteristics of the CE programs

\begin{tabular}{|c|c|c|c|c|c|}
\hline Study & Contents & Didactic strategies & Participunts & $\begin{array}{l}\text { Fackeround } \\
\text { instructor(s) }\end{array}$ & Duration \\
\hline $\begin{array}{l}\text { Camp-Sorrell \& } \\
\text { O'Sullivan "9I }\end{array}$ & $\begin{array}{l}\text { Program A: } \\
\text { areas which should be documented after pain asuesumenl (e.g- location, quaity. } \\
\text { pattern) } \\
\text {-MeGill Pain Questionnaire } \\
\text { Program B: the sams, but no McGill Pain Questionnaire }\end{array}$ & $\begin{array}{l}\text {-life instruction } \\
\text {-practical exercise } \\
\text {-feedback on pain } \\
\text { doctumentation }\end{array}$ & $\begin{array}{l}\text { nurses } \\
\text { (area:medical and } \\
\text { surgical oncology) }\end{array}$ & $\begin{array}{l}\text { nuning and } \\
\text { efucation }\end{array}$ & $\begin{array}{l}\text { A5 minutes } \\
\eta \eta \text { (unciear) }\end{array}$ \\
\hline $\begin{array}{l}\text { Dalton ef al } \\
95\end{array}$ & $\begin{array}{l}\text {-pain assessment } \\
\text {-phanmacological therapies } \\
\text {-nonplarmacological therapies } \\
\text { ethical and regulatory isues } \\
\text { benefits of a coordinated-care program in rural areas }\end{array}$ & $\begin{array}{l}\text {-seminat discusaion } \\
\text {-participation in hospital } \\
\text { rourda } \\
\text {-direat plyyical and } \\
\text { prychosocial assessment } \\
\text {-continuous interaction } \\
\text { with the teaching tearn } \\
\text {-liternture }\end{array}$ & $\begin{array}{l}\text { munes } \\
\text { (in runal areas) }\end{array}$ & $\begin{array}{l}\text { multidiaciplinary } \\
\text { (nursing. phamacy. } \\
\text { medicine, } \\
\text { psychology) }\end{array}$ & 6 days \\
\hline Davis ' 8 ". & pain assesument chart & $\begin{array}{l}\text { - Meture } \\
\text {-video } \\
\text {-discussion }\end{array}$ & $\begin{array}{l}\text { nunes } \\
\text { (area:orthoypedic } \\
\text { surgery) }\end{array}$ & $\begin{array}{l}\text { aursing? and } \\
\text { education?? } \\
\text { (unclear) }\end{array}$ & $\begin{array}{l}7 ? \text { hours in } \\
1 \text { month } \\
\text { (unclear) }\end{array}$ \\
\hline $\begin{array}{l}\text { Degner at al. } \\
\text { ' } 82 \cdots\end{array}$ & 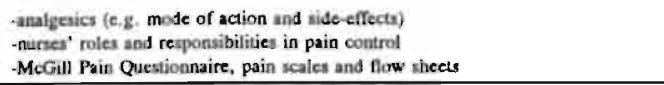 & $\begin{array}{l}\text {-life instruction } \\
\text {-discussion }\end{array}$ & $\begin{array}{l}\text { nuries } \\
\text { (area:oncology) }\end{array}$ & pharmacy? (unclear) & $\begin{array}{l}? ? \text { (nol } \\
\text { given) }\end{array}$ \\
\hline Dols et al. '95 & $\begin{array}{l}\text {-pain assessment methods } \\
\text {-decision-making and pain assessment }\end{array}$ & 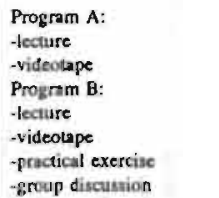 & $\begin{array}{l}\text { nurses } \\
\text { (area:unclear) }\end{array}$ & $\begin{array}{l}\text { nursing?? } \\
\text { (unclear) }\end{array}$ & $\begin{array}{l}? ? \text { (not } \\
\text { given) }\end{array}$ \\
\hline
\end{tabular}

Explanation of signs: see below Tabie 2.1 (consinued II) 


\begin{tabular}{|c|c|c|c|c|c|}
\hline Study & Contents & Didactic strategies & Participants & $\begin{array}{l}\text { Buckground } \\
\text { instructor(s) }\end{array}$ & Duration \\
\hline $\begin{array}{l}\text { Ferreil et al. } \\
.93\end{array}$ & $\begin{array}{l}\text {-pain and pain assessment (e.g. pain racing scale) } \\
\text {-pharmacological paic management (c.g. side-effects) } \\
\text {-nonphamacological interventions (e.g. Jistraction and education) } \\
\text {-cultural, elhical and psychosecial aspects of pain }\end{array}$ & $\begin{array}{l}\text {-life instruction } \\
\text {-discussion } \\
\text {-group exercise } \\
\text {-clinical practice }\end{array}$ & $\begin{array}{l}\text { murses } \\
\text { (areas:inpatient and } \\
\text { outpatient care) }\end{array}$ & $\begin{array}{l}\text { nursing?? } \\
\text { (unclear) }\end{array}$ & 40 hours \\
\hline Foglesong ' 83 & $\begin{array}{l}\text {-McCaffery's definition of pain } \\
\text {-analgesica (e. \&. side-effects and preventive aspects) } \\
\text {-benefits of pain relief for brealking, coughing, mobility } \\
\text {-pain and sleep }\end{array}$ & $\begin{array}{l}\text {-life instruction } \\
\text {-fcedback on pain } \\
\text { documentation }\end{array}$ & $\begin{array}{l}\text { nurses } \\
\text { (area:surgery) }\end{array}$ & $\begin{array}{l}\text { nursing?? } \\
\text { (uncleas) }\end{array}$ & $\begin{array}{l}6 \text { hours?? } \\
\text { (unclear) }\end{array}$ \\
\hline $\begin{array}{l}\text { Foglesong et al. } \\
\text { '87 }\end{array}$ & the same as Foglesong ' 83 & $\begin{array}{l}\text { the same as Foglesong } \\
\text { '83 }\end{array}$ & $\begin{array}{l}\text { nurses } \\
\text { (area:surgery) }\end{array}$ & nurving & 6 hours \\
\hline Hauck ' 86 & $\begin{array}{l}\text {-attitudes, misconceptions and theories conceraing pain } \\
\text {-assersment of pain } \\
\text {-amalgesia and side effect mamagemend techniques }\end{array}$ & $\begin{array}{l}\text { - lecture } \\
\text {-discussion } \\
\text {-vigneries/slides } \\
\text {-literature }\end{array}$ & $\begin{array}{l}\text { nursts } \\
\text { (nres:oncology) }\end{array}$ & $\begin{array}{l}\text { nursing?? } \\
\text { (unclear) }\end{array}$ & 2 hours \\
\hline $\begin{array}{l}\text { Mocardie \& } \\
\text { Y.d. Wiel } \\
93^{* \ldots}\end{array}$ & $\begin{array}{l}\text {-pain assessment questionnaire } \\
\text {-other aspects related to pain?? (Unclear) }\end{array}$ & ?? (not given) & $\begin{array}{l}\text { nurses } \\
\text { (area:oncology) }\end{array}$ & $\begin{array}{l}\text { nursing?? } \\
\text { (unclear) }\end{array}$ & $\begin{array}{l}45 \\
\text { minutes } \cdots . .\end{array}$ \\
\hline
\end{tabular}

Explaration of signs: see below Table 2.1 (continued II) 
Tabie 2.1. (cortinued II)

\begin{tabular}{|c|c|c|c|c|c|}
\hline Study & Contents & Didactic atrategies & Participants & Background instructor(s) & Duration \\
\hline $\begin{array}{l}\text { MeNaull et al. } \\
92\end{array}$ & $\begin{array}{l}\text {-assestment and documentation of pain using a } \\
\text { numerical rating scale }\end{array}$ & $\begin{array}{l}\text { Program A:written instruction } \\
\text { Prograin B:the aame as program A + personal } \\
\text { inatruetion of is misules } \\
\text { Prograim C:the same as progracr B + postex } \\
\text { presentation } \\
\text { Program D:the ame: us program B + video }\end{array}$ & $\begin{array}{l}\text { nurses } \\
\text { (areas: medical and } \\
\text { surgical nursing) }\end{array}$ & $\begin{array}{l}\text { nursing?? } \\
\text { (uncleas) }\end{array}$ & $\begin{array}{l}\text { less than } 30 \\
\text { minutes }\end{array}$ \\
\hline $\begin{array}{l}\text { Meyerinik et } \\
\text { al. "9.4* }\end{array}$ & $\begin{array}{l}\text { - pain assestmes queationsaire } \\
\text {-dimensions of pain } \\
\text {-medical. physio-and psychotherapeucic interventions } \\
\text {-nonpharmacological interventions (e.g. psychosocial } \\
\text { ifterventions and distraction) }\end{array}$ & $\begin{array}{l}\text {-tecture } \\
\text {-discussion } \\
\text {-practical exercise } \\
\text {-literature }\end{array}$ & $\begin{array}{l}\text { nurses } \\
\text { (area:oncology) }\end{array}$ & $\begin{array}{l}\text { nursing, medicine, } \\
\text { physiotherapy. } \\
\text { psychotherapy and social } \\
\text { woik }\end{array}$ & 8 hours \\
\hline Myers 85 & $\begin{array}{l}\text {-incidence and causes of cancer related pain } \\
\text {-assessment and management of acute and cirronic pain } \\
\text {-analgesics (c.g-side-effects and benefits of scheduled } \\
\text { auministration) }\end{array}$ & ?? (not given) & $\begin{array}{l}\text { nurses } \\
\text { (arca:oncology) }\end{array}$ & $\begin{array}{l}\text { nuning?? } \\
\text { (uncleai) }\end{array}$ & 3 hours \\
\hline Sofaer ' 84 & $\begin{array}{l}\text {-psychological and cultural aspects of pain } \\
\text {-asseasment of pain } \\
\text { (c.g. pain meacurement instruments) } \\
\text {-pharmacological therapies } \\
\text {-noapharmacological interventions } \\
\text { (c.g. communication, relaxation and distraction) }\end{array}$ & $\begin{array}{l}\text {-discussion } \\
\text {-roie play } \\
\text {-proctical exercise } \\
\text {-literature }\end{array}$ & $\begin{array}{l}\text { nurses } \\
\text { (areas:general and } \\
\text { onhopedic } \\
\text { surgery, and } \\
\text { gynaecology) }\end{array}$ & nursing & $\begin{array}{l}4 \times 77 \\
\text { hours } \\
\text { (unclear) }\end{array}$ \\
\hline $\begin{array}{l}\text { Weissman et } \\
\text { at. ' } 917 \text { '93 }\end{array}$ & $\begin{array}{l}\text {-historic and eulture! ispects of pain (management) } \\
\text {-haniers to cancer pain management } \\
\text {-assessment of pain } \\
\text {-phamacology and side-effeets of analgesics } \\
\text {-anaesthetic, neurosurgical and behavioral therapies }\end{array}$ & $\begin{array}{l}\text {-life insinution } \\
\text {-workshop } \\
\text {-action plan }\end{array}$ & $\begin{array}{l}\text { doctors, nurses. } \\
\text { pharmacists } \\
\text { (area:oncology) }\end{array}$ & $\begin{array}{l}\text { medicine?? and } \\
\text { psychotherapy?? } \\
\text { (unclear) }\end{array}$ & 1 day \\
\hline $\begin{array}{l}\text { Westall \& } \\
\text { Speedie } 81\end{array}$ & -pharmacology and (side-)effects of analgesics & $\begin{array}{l}\text {-life insiruction } \\
\text {-dikcussion } \\
\text {-literature }\end{array}$ & $\begin{array}{l}\text { nurses } \\
\text { (area:geriatrics) }\end{array}$ & phamacy & $\begin{array}{l}? 7 \times 1-2 \\
\text { hours } \\
\text { (unclear) }\end{array}$ \\
\hline
\end{tabular}

Explanation, of aigns:

- = This program was combined with the formal implectentation of a pain assessment tool.

- - This program was combined with the formal impiemertation of a new pharmacelogical pain policy.

*.* = This program was part of a three day oncology program. 


\section{Continuing pain education}

The studies do not explicitly report what kind of educational method or theoreticaleducational premises (e.g. according to 'Confluent Education', see Chapter 4) were used. However, information is often provided about the specific didactic strategies. Dols et al. (1995), for instance, describe how they implemented and compared two CE programs. Nurses in program A received only a lecture and watched a videotape, while nurses in program B also participated in a group discussion and a practical exercise (see Table 2.1).

In the majority of the programs, participants and instructors had a nursing background. Participants mainly worked in the areas of oncology, orthopaedics or surgery (see Table 2.1). Westfall and Speedie's program (1981) for geriatric nurses was an exception in this respect.

Information is not always given about the duration of the programs. Nonetheless, it appears that the majority were of short duration: eight hours or less (see Table 2.1). The durations of the forty-hour program of Ferrell et al. (1983) and the six-day program of Dalton et al. (1995) are exceptional.

Critical comments. Nurses' knowledge about pain, assessments of pain and pharmacological pain management is often poor (e.g. Carr, 1990; Grossman et al., 1991; Lieb Zalon, 1993; Paice et al., 1991). Therefore, it is good that a relatively high proportion of programs paid attention to these topics. However, since a combination of pharmacological and nonpharmacological methods probably provides the most pain relief (McCaffery, 1990), it is remarkable that only four programs (Dalton et al. 1995; Ferrell et al., 1993; Meyerink et al., 1994; Sofaer, 1984) also dealt with nonpharmacological nursing interventions (such as psychosocial and relaxation interventions).

As described, the target group(s) nearly always concerned oncological, orthopedic and surgical care providers. However, pain programs may also be necessary for other nurses (e.g. paediatric and geriatric nurses) caring for patients in pain.

\section{Research methods}

Characteristics. Several research designs were used to assess program effectiveness. A design without a control group, and with posttest(s) only, was used in three of the sixteen studies reviewed (Degner et al., 1982; McCardle \& Van der Wiel, 1993; Weissman et al., 1991 and 1993). This design appears to have been chosen for practical reasons. McCardle and Van der Wiel (1993), for instance, state that due to limited financial resources they were unable to involve control groups or take additional measurements.

The studies of Dols et al. (1995) and McNaull et al. (1992), whose aim was to compare program variants with different didactic strategies, also employed a design with only a posttest, but with several treatment groups.

The most commonly used was a pretest-posttest design without control group. Eight of the sixteen studies used this design (Dalton et al., 1995; Davis, 1988; Ferrell et al., 1993; Foglesong, 1983; Foglesong et al., 1987; Meyerink et al., 1994; Myers, 1985; Sofaer, 1984). Sofaer (1984) states that it is difficult to randomize in a clinical setting, which was for her an important consideration in choosing an uncontrolled design. Sofaer 
Table 2.2. Methods and findings

\begin{tabular}{|c|c|c|c|c|c|c|c|c|}
\hline \multirow[t]{2}{*}{ Study } & \multirow[t]{2}{*}{ Design } & \multirow{2}{*}{$\begin{array}{l}\text { Randomization } \\
\text { adjuntmen/ } \\
\text { restriction/ } \\
\text { matching }\end{array}$} & \multicolumn{3}{|l|}{ Sample of } & \multirow{2}{*}{$\begin{array}{l}\text { Methods/instruments used } \\
\text { for messuring effects }\end{array}$} & \multirow{2}{*}{$\begin{array}{l}\text { Procedures of } \\
\text { andilysis }\end{array}$} & \multirow[t]{2}{*}{ Effects } \\
\hline & & & $\begin{array}{l}\text { care } \\
\text { proviseers }\end{array}$ & patients & files & & & \\
\hline $\begin{array}{l}\text { Camp-Sorrell \& } \\
\text { O'Sullivan '91 }\end{array}$ & $\begin{array}{l}\text { preteg-posttent desigs with rwo } \\
\text { tealment groups and rando- } \\
\text { suization of nuring units } \\
\text { dast measurements: } 2 \text { months } \\
\text { afler program) }\end{array}$ & $\begin{array}{l}\text { nndomization } \\
\text { and statistica! } \\
\text { adjustment }\end{array}$ & - & - & 44 & $\begin{array}{l}\text { chart audit, using a self- } \\
\text { developed form (conlent } \\
\text { validity established, } \\
\text { reliability??) }\end{array}$ & $\begin{array}{l}\text { MANCOVA and } \\
\text { ANCOVA for } \\
\text { repeated } \\
\text { measures }\end{array}$ & -nurnes. pais. documentation:0 \\
\hline Dalton el al. '9s & $\begin{array}{l}\text { pretest-postest design without } \\
\text { control group (lat } \\
\text { measurenents: } 12 \text { monhs inter } \\
\text { program) }\end{array}$ & ? (unclesr) & 29 & $\begin{array}{l}\text { loul: 139, } \\
\text { remaining } \\
\text { in follow- } \\
\text { up: } 2.2\end{array}$ & $\begin{array}{l}210,184 \\
161,92 \\
+298\end{array}$ & $\begin{array}{l}\text { chart audit and } \\
\text { questionnaires on } \\
\text { knowledge, atlitudes and } \\
\text { behavior (validity and } \\
\text { reliability??) }\end{array}$ & $\begin{array}{l}\text { P? (not given, } \\
\text { analyien are } \\
\text { underway) }\end{array}$ & -program's effects: probably + \\
\hline \multirow[t]{2}{*}{ Davis '88 } & \multirow{2}{*}{$\begin{array}{l}\text { prelest-postest design wilhout } \\
\text { control group } \\
\text { (last measurements: just after } \\
\text { program) }\end{array}$} & \multirow[t]{2}{*}{-} & \multirow[t]{2}{*}{17} & \multirow[t]{2}{*}{-} & \multirow[t]{2}{*}{-} & $\begin{array}{l}\text { self-developed 'Attitude to } \\
\text { Pain Control Scale' (validity } \\
\text { and reliability??) }\end{array}$ & $\begin{array}{l}\text { descripive } \\
\text { statistics }\end{array}$ & $\begin{array}{l}\text {-murses' icuitudes lo pain } \\
\text { control:- }\end{array}$ \\
\hline & & & & & & $\begin{array}{l}\text { self-developed knowledge } \\
\text { questionuaires (validity and } \\
\text { reliability??) }\end{array}$ & ?? (nor given) & ?? (nor given) \\
\hline \multirow[t]{3}{*}{ Degnet et al :82 } & \multirow{3}{*}{$\begin{array}{l}\text { devign without control group, } \\
\text { with postest only (1 year a fier } \\
\text { program), and retrospective } \\
\text { chart audit }\end{array}$} & \multirow[t]{3}{*}{-} & \multirow[t]{3}{*}{$? ?$ funclear) } & \multirow[t]{3}{*}{$\begin{array}{l}? ? \\
\text { (unclear) }\end{array}$} & \multirow[t]{3}{*}{$\begin{array}{l}? ? \\
\text { (unclest) }\end{array}$} & $\begin{array}{l}\text { interviews with suft } \\
\text { (validity and reliability??) }\end{array}$ & $\begin{array}{l}\text { qualitative } \\
\text { anafysis?? } \\
\text { (unclear) }\end{array}$ & $\begin{array}{l}\text {-matients' energy to altend to } \\
\text { emotional concerns: + } \\
\text {-staft stress:- }\end{array}$ \\
\hline & & & & & & \multirow[t]{2}{*}{$\begin{array}{l}\text { chart audit (validily and } \\
\text { reliability??) }\end{array}$} & $\begin{array}{l}\text { descriptive } \\
\text { statistics }\end{array}$ & $\begin{array}{l}\text {-analgesics prescribed and } \\
\text { administered: }+\end{array}$ \\
\hline & & & & & & & $\begin{array}{l}\text { descriptive } \\
\text { stalistics?? } \\
\text { (unciear) }\end{array}$ & $\begin{array}{l}\text {-time lag between pain } \\
\text { appeararce and relief: }+ \\
\text {-patients' quality of life: + } \\
\text {-cost-efficacy: }+\end{array}$ \\
\hline
\end{tabular}

Explanation of signs: see below Table 2.2 (continued III) 


\begin{tabular}{|c|c|c|c|c|c|c|c|c|}
\hline \multirow[t]{2}{*}{ Study } & \multirow[t]{2}{*}{ Design } & \multirow{2}{*}{$\begin{array}{l}\text { Randonization/ } \\
\text { adjustment } \\
\text { restriction/ } \\
\text { matching }\end{array}$} & \multicolumn{3}{|l|}{ Sample of } & \multirow{2}{*}{$\begin{array}{l}\text { Methods/instruments used } \\
\text { for measuring effeas }\end{array}$} & \multirow{2}{*}{$\begin{array}{l}\text { Procedures of } \\
\text { analysis }\end{array}$} & \multirow[t]{2}{*}{ Errects } \\
\hline & & & $\begin{array}{l}\text { care } \\
\text { providers }\end{array}$ & patients & files & & & \\
\hline Dols et al. '99 & $\begin{array}{l}\text { design with two different } \\
\text { treaument groups, and with } \\
\text { postuest only } \\
\text { (last measurements; few days } \\
\text { afler program) }\end{array}$ & - & 29 & - & - & $\begin{array}{l}\text { 'Nurses' Knowledge and } \\
\text { Atitudes Survey' (developed } \\
\text { by Ferrell et al.; content and } \\
\text { construa validity, tesi-relest } \\
\text { reliability, and interna! } \\
\text { consistency established) }\end{array}$ & $\mathrm{X}^{2}$ - tests & $\begin{array}{l}\text {-no differences in outcornes } \\
\text { between lwo treatment } \\
\text { groups with respect to use } \\
\text { of patients" reports in pain } \\
\text { assessment }\end{array}$ \\
\hline \multirow[t]{2}{*}{$\begin{array}{l}\text { Ferreil el al. } \\
993\end{array}$} & \multirow[t]{2}{*}{$\begin{array}{l}\text { presest-postcest design witbowt } \\
\text { control group } \\
\text { (last measurements: } 3 \text { months } \\
\text { after program) }\end{array}$} & \multirow[t]{2}{*}{ - } & \multirow[t]{2}{*}{26} & \multirow[t]{2}{*}{-} & \multirow[t]{2}{*}{-} & $\begin{array}{l}\text { self-developed 'Nurses' } \\
\text { Knowledge and Anitudes } \\
\text { Survey' (validity and } \\
\text { reliability??) }\end{array}$ & $\begin{array}{l}\text { descriptive } \\
\text { statistics }\end{array}$ & $\begin{array}{l}\text {-nurses' knowledge and } \\
\text { attiudes coscerning pain } \\
\text { and pain nanagement: + }\end{array}$ \\
\hline & & & & & & $\begin{array}{l}\text { self-developed evaluation } \\
\text { survey (validiny and } \\
\text { reilability??) }\end{array}$ & $\begin{array}{l}\text { descriptive } \\
\text { statistics?? } \\
\text { (unclear) }\end{array}$ & $\begin{array}{l}\text {-nurses' amount of teaching } \\
\text { patiens and coworkers: + } \\
\text {-other outcomes:?? } \\
\text { (unclear) }\end{array}$ \\
\hline Foglesong 'B3 & $\begin{array}{l}\text { pretest-posttest design withoul } \\
\text { conntrol group } \\
\text { (last messurements: 3-4 weeks } \\
\text { ofter program) }\end{array}$ & restriction & - & - & $2 \times 20$ & $\begin{array}{l}\text { chart audil. using self- } \\
\text { developed crileria (validity } \\
\text { and reliability??) }\end{array}$ & $\begin{array}{l}\text { descriptive } \\
\text { statistics }\end{array}$ & $\begin{array}{l}\text {-analgesics administered : + } \\
\text {-patients' pain relief: + }\end{array}$ \\
\hline $\begin{array}{l}\text { Fuglesong at } \\
\text { al. } 87\end{array}$ & the sume as Foglesong ' 83 & restriation & -- & - & $2 \times 32$ & the same as Foglesong ' 83 & $\begin{array}{l}\text { descriptive } \\
\text { statistics }\end{array}$ & $\begin{array}{l}\text {-analgesics administered + } \\
\text {-patienis' pain relief:+ }\end{array}$ \\
\hline \multirow[t]{2}{*}{ Hauck ' 86} & \multirow[t]{2}{*}{$\begin{array}{l}\text { pretest-postest nongandonized } \\
\text { control gruup design } \\
\text { (last measurements: } 3 \text { diys } \\
\text { after program) }\end{array}$} & \multirow[t]{2}{*}{-} & \multirow[t]{2}{*}{$s 2$} & \multirow[t]{2}{*}{-} & \multirow[t]{2}{*}{-} & $\begin{array}{l}\text { seif-developed knowledze } \\
\text { questionnsire (parially based } \\
\text { on an instrument of Fox. } \\
\text { Content validity established, } \\
\text { intemal reliability was } \\
\text { modente) }\end{array}$ & t-test & $\begin{array}{l}\text {-nurses' knowiedge of } \\
\text { analgesics: }+\end{array}$ \\
\hline & & & & & & $\begin{array}{l}\text { self-developed attitude } \\
\text { inventory (content validity } \\
\text { established, reliability??) }\end{array}$ & t-lest & $\begin{array}{l}\text { - תurses' attitudes toward } \\
\text { cancer patienls in pain: + }\end{array}$ \\
\hline
\end{tabular}


Table 2.2 (continued II)

\begin{tabular}{|c|c|c|c|c|c|c|c|c|}
\hline \multirow[t]{2}{*}{ Study } & \multirow[t]{2}{*}{ Deaign* } & \multirow{2}{*}{$\begin{array}{l}\text { Randomization/ } \\
\text { adjusiment/ } \\
\text { restriction/ } \\
\text { matching }\end{array}$} & \multicolumn{3}{|l|}{ Sample of } & \multirow{2}{*}{$\begin{array}{l}\text { Meihods/lnstruments used for } \\
\text { mesisuring effects* }\end{array}$} & \multirow{2}{*}{$\begin{array}{l}\text { Procedures of } \\
\text { anulysis }\end{array}$} & \multirow[t]{2}{*}{ Effucts } \\
\hline & & & $\begin{array}{l}\text { care } \\
\text { providers }\end{array}$ & patients & fites & & & \\
\hline $\begin{array}{l}\text { McCurdle \& } \\
\text { v.d. Wiel ' } 93\end{array}$ & $\begin{array}{l}\text { detign without control } \\
\text { group, with postest only } \\
\text { (2 years alter program) }\end{array}$ & - & 16 & - & - & $\begin{array}{l}\text { interview's, semi-structured } \\
\text { by a self-teveloped } \\
\text { questionnaire (validily and } \\
\text { reliability??) }\end{array}$ & $\begin{array}{l}\text { qualitative } \\
\text { amalysis and } \\
\text { Jescriptive } \\
\text { slatistics }\end{array}$ & $\begin{array}{l}\text {-nurses' use of pain } \\
\text { questionraire:few/ } \\
\text {-eflectiveness of interventions: + } \\
\text {-nunes' insight into pain:- } \\
\text {-nurses' attention for pain : + }\end{array}$ \\
\hline $\begin{array}{l}\text { MeNaull et al. } \\
\cdot 92\end{array}$ & $\begin{array}{l}\text { design with four different } \\
\text { ueatment groups, and with } \\
\text { postest only } \\
\text { (last measurements: few } \\
\text { weeks after program) }\end{array}$ & $\begin{array}{l}\text { statistical } \\
\text { sjusumens }\end{array}$ & 39 & - & 66 & $\begin{array}{l}\text { char sudit (validity and } \\
\text { reliability??) }\end{array}$ & $\begin{array}{l}\text { ANOVA and } \\
\text { ANCOVA }\end{array}$ & $\begin{array}{l}\text {-significant differences in use of } \\
\text { the rating scale arnong the four } \\
\text { treatment groups (nurnes } \\
\text { receiving video were more likely } \\
\text { to use the scale) }\end{array}$ \\
\hline $\begin{array}{l}\text { Meyerink el al. } \\
=94\end{array}$ & $\begin{array}{l}\text { pretede-posttest design } \\
\text { without control group } \\
\text { (last incasurements: ?? } \\
\text { weeks a fler program) }\end{array}$ & resuriction & - & - & $\begin{array}{l}42+ \\
62\end{array}$ & $\begin{array}{l}\text { chan audit, using a self- } \\
\text { developed scheduje (validity } \\
\text { and reliability??) }\end{array}$ & $\begin{array}{l}\text { dexcriplive } \\
\text { stalistics }\end{array}$ & -nurses' atlention for pain: + \\
\hline Myers 'Bs & $\begin{array}{l}\text { pretest-posteas design } \\
\text { withoul control group } \\
\text { (12st measurements: } 2 \\
\text { weeks a fler prognam) }\end{array}$ & - & 65 & - & - & $\begin{array}{l}\text { self-developed 'Knowledge } \\
\text { and Altitudes towerd } \\
\text { Management of Cancer Pain } \\
\text { Tool' (content validity and } \\
\text { reliability established) }\end{array}$ & $\begin{array}{l}\text { ANOVA for } \\
\text { repeated } \\
\text { measures }\end{array}$ & $\begin{array}{l}\text {-nures' knowledge and atindes } \\
\text { with respect to pain: + }\end{array}$ \\
\hline
\end{tabular}

Explanation of signs: see below Table 2.2 (continued II) 


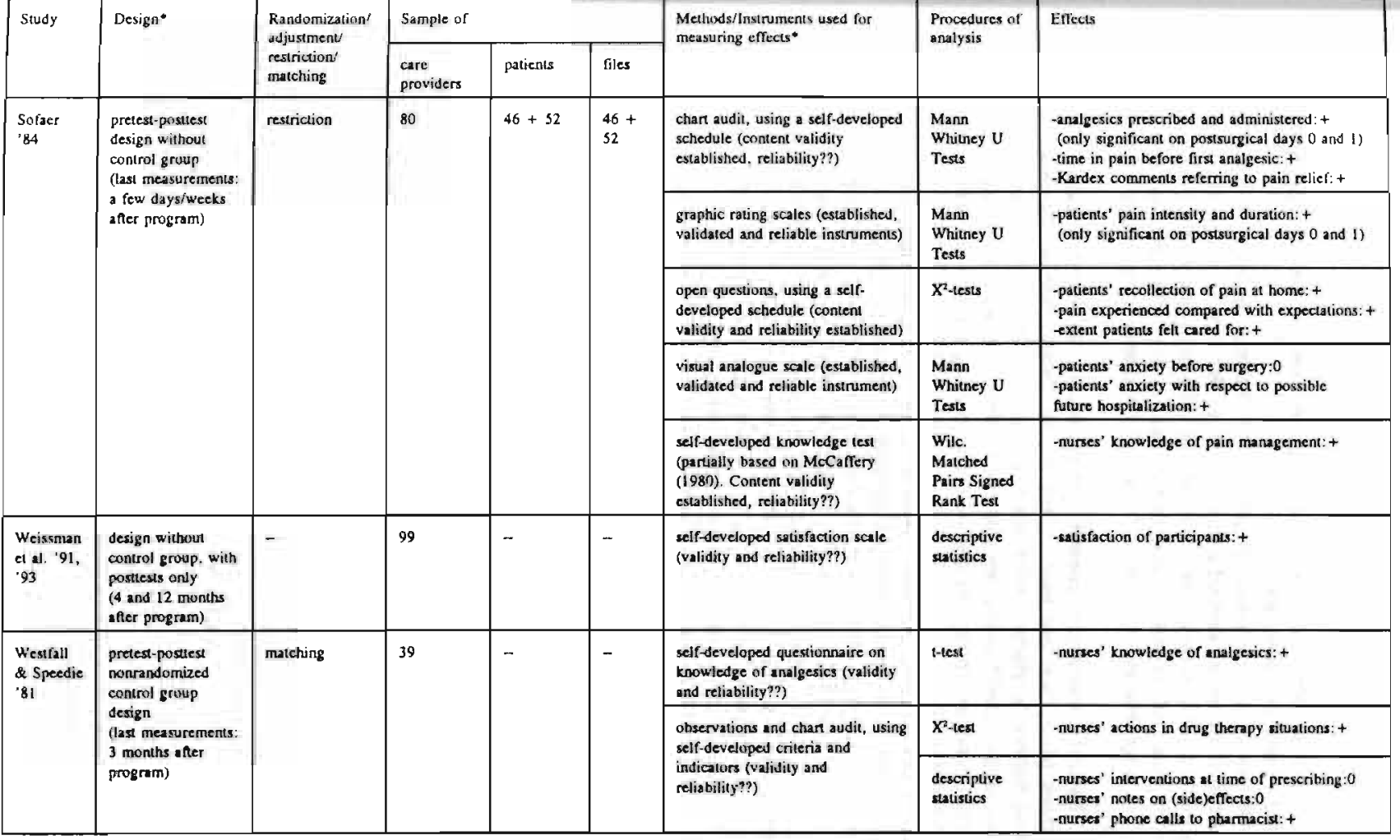

\section{Explanation of signs:}

- Measurements, instrumerus or methods which are only used for assessing leaming needs are nol mentioned in Tuble 2.2 .

$+=$ Positive effects: $0=$ no positive effects. 
and the other authors who chose for this design do not discuss the possibility of a nonrandomized control group design.

Two of the studies reviewed (Hauck, 1986; Westfall \& Speedie, 1981) used a pretest-posttest nonrandomized control group design. In Westfall and Speedie's study, two nursing homes received a program and two did not. The assignment of the homes to the two conditions was not randomly determined due to the difference in size of the participating nursing homes. conditions was not randomly determined (Westfall \& Speedie, 1981).

The classical randomized control group design, in which randomization of individuals takes place, was not used in any of the sixteen studies. However, CampSorrell and O'Sullivan's study (199l) used a variant of this design and performed randomization 'at unit level': in one hospital two nursing units were randomly allocated to the experimental condition (program) and two other nursing units to the control condition (alternative program).

Besides randomization, statistical adjustment, restriction and matching (Francke \& Duivenvoorden, 1993; Rothman, 1986) may also eliminate the effect of confounding variables, and consequently enhance internal validity. The studies of Camp-Sorrell and O'Sullivan (1991) and McNaull et al. (1992) are the only ones using statistical adjustment. Camp-Sorrell and O'Sullivan, for instance, utilized a MANCOVA and ANCOVA procedure (Stevens, 1986) in which the baseline score on the variable pain documentation was involved as a covariate. In four studies (Foglesong, 1983; Foglesong ut al., 1987; Meyerink et al., 1994; Sofaer, 1984) restriction was applied. For instance, Foglesong (1983) and Foglesong et al. (1987) selected patients on the basis of age and postoperative use of pain medication (type of operation was uncontrolled). Matching was used only in Wesifall and Speedie's study (1981): the four nursing homes involved were assigned to the conditions on the basis of similarities in characteristics, such as the medical problems of patients admitted.

Posttests were often within a few days or weeks after the program (see Table 2.2). Only in five studies posttests did take place some months or years after the program (Dalton et al., 1995; Degner et al., 1982, Ferrell et al., 1993; McCardle \& Van der Wiel, 1993; Weissman et al., 1991 and 1993).

In the majority of studies, only the effects of the programs on health care providers were studied (see Table 2.2). With the exception of the study of Weissman et al. (1991 and 1993) in which nurses and doctors participated together, these care providers all had a nursing background. Sample sizes of care providers varied from sixteen (McCardle \& Van Der Wiel, 1993) to ninety-nine (Weissman et al., 1991 and 1993). For samples of patients or patient files, sample sizes varied from forty (Foglesong, 1983) to 298 (Dalton et al., 1995).

Sofaer (1984) and Dols et al. (1995) used some existent, valid and reliable instruments. Sofaer used visual and graphic rating scales (besides self-developed instruments) and Dols et al. used the Pain Management Nurses' Knowledge and Attitude Survey (sce Table 2.2). Other authors do not repor which instruments they used, or employed only self-developed quantitative or qualitative instruments (often based on relevant literature or available instruments). Some authors provide psychometric information on the validity and reliability of the instruments they developed themselves, 
while others do not (see Table 2.2).

In addition, not all researchers provide clear information about the analysis procedures (see Table 2.2). However, most researchers who do provide this information restricted themselves to descriptive statistics in the form of frequencies or percentages. Those who applied inferential statistics (Camp-Sorrell \& O'Sullivan. 1991; Dols et al., 1995; Hauck, 1986; Myers, 1985; Sofaer, 1984: Westfall \& Speedie, 1981) used mostly analysis of variance techniques, Mann Whitney $U$ tests and $X^{2}$-tests.

Critical comments. As described, only a few studies utilized control groups. Uncontrolled studies, however, provide limited insight into the extent to which effects are produced by the program or by other factors (e.g. organizational changes). Drawing valid inferences about effects of a program really becomes precarious when pretests must also be dispensed with.

The Camp-Sorrell and O'Sullivan study (1983) illustrates that randomization of nursing units/wards is a practical alternative to randomization of individuals (Diwan et al., 1992). Randomization at unit or ward level may not mean that all experimental subjects will be comparable to controls in all respects. However, it may, for instance, diminish the chance that all highly motivated subjects will be allocated to the experimental condition and all less motivated to the control condition.

It is important to make a relevant choice in the variable(s) being controlled when statistical adjustment, restriction or matching are used. Such procedures are of less value when a significant confounding variable is ignored (e.g. when the type of operation is uncontrolled, as was the case in the Foglesong study of 1983 and the Foglesong et al. study of 1987),

In most of the studies the last posttests occurred remarkably soon after the program. Yet, the CE literature indicates that there is a high probability that what has been learned may fade in the course of time (Fielding \& Llewelyn, 1987). For this reason, it is unfortunate that most studies made no measurements after a longer time had elapsed.

Established instruments were rarely used. An explanation may be that these instruments are not always well attuned to a certain program's content and target group. Nevertheless, to improve the quality and comparability of CE studies, the use of established, validated and reliable instruments is recommended wherever possible. If existent instruments are not useful in their totality, portions can be utilized to develop new instruments, as some authors did (see Table 2.2). However, in that case, researchers are obligated to study and report psychometric qualities.

Many studies used only descriptive statistics. However, in the context of an effectoriented study, it is advisable to gain insight into the statistical significance of results (this may not apply to process-oriented or pilot studies). Otherwise, it will remain unclear whether changes should be considered as more than a chance finding. Whenever inferential statistics are used, it is important that this be done properly. A few studies require comment in this respect. For instance, in two studies (Hauck, 1986; Westfall \& Speedie, 1981) an experimental and a control group were compared by applying two ttests: one for pretests and one for posttests. An ANOVA procedure would have been more appropriate because there were four groups (two prior and two subsequent to the 
program). An ANOVA for repeated measures was performed in Myers' study (1985) involving three measurement points. However, the preferred method in cases of more than two measurements is the MAN(C)OVA for repeated measures (Stevens, 1986).

As also described, in most of the studies reviewed, the sample sizes (per measurement and per condition) were rather small. Still, except for Camp-Sorrell and O'Sultivan's study (1983), significant results can be shown in all studies where inferential statistics were used. This indicates that the sample sizes of most studies that employed inferential statistics were adequate.

\section{Effects}

Characteristics. Nearly all authors who assessed effects on nurses, report positive effects on nurses' knowledge, attitudes or interventions (see Table 2.2). Only Camp-Sorrell and O'Sullivan (1991) did not find any significant changes. They attributed the lack of positive results to such factors as the short duration of their program and the fact that no attention was paid to nursing interventions.

The studies in which effects on patients were assessed, all showed positive results (see Table 2.2). The Foglesong (1983) and Foglesong et al. studies (1987) demonstrated that in comparison with patients nursed before the program, patients after the program received more pain medication during the first twenty-four postoperative hours. Sofaer's study (1984) showed comparable results: patients nursed after the program received more pain medication, particularly during the first two postsurgical days. These patients demonstrated lower pain intensity and shorter pain duration. Degner et al. (1982) demonstrated an increase in the administration of analgesics after the program and an increase in the quality of life and pain-free periods. Consequently, patients had more energy to stand up for themselves in interactions with nurses and doctors, which seemed to have resulted in more stress for the staff (Degner et al.. 1982).

Critical comments. Research findings are more likely to be published when positive effects have been established, rather than when no, or negative, effects are found. The probability of publication bias, as well as the differences between the programs and between the evaluation instruments, methodological limitations and the small number of studies, hinder a general statement about the effectiveness of continuing pain education. The limited number of only five published studies concerning effects on patients shows how little is known.

Conclusions about programs' effects are also difficult to make, because the statistical significance of effects shown in some studies says little about clinical relevance. However, it can be assumed that studies also exhibiting effects in terms of patient results always have at least some clinical relevance.

\section{Discussion}

Although the sixteen studies examined do not constitute conclusive evidence, they do indicate that continuing pain education can have an impact on both nurses and patients. Future methodologically sound studies should reveal to what extent pain programs for 
nurses have a positive impact and what types of programs are particularly effective.

It is advisable to use randomized controlled designs, established instruments, long term follow-up measurements and inferential statistics more often in future studies. This will enable firmer conclusions to be drawn on the effectiveness of pain CE programs.

It is also advisable to pay special attention to the effects on patients because of the limited number of such studies to date. This would provide more insight into whether the ultimate goal of nursing CE, i.e. promoting health care (American Nurses Association, 1975 and 1986), is achieved.

In future program development, it is essential to critically evaluate the content of previous programs. So far, there has been little attention focused on nonpharmacological pain interventions which are also part of the nursing domain (Herr, 1992; VWR/CBO, 1994). Accordingly, these interventions certainly ought to be included in some future programs.

Finally, a lesson can be distilled from the fact that previous publications often did not report all relevant information on program characteristics and research methods (see Tables 2.1 and 2.2). More complete reports would give other researchers better opportunities for interpreting effects and for comparing and replicating studies.

\section{References}

Abbott FV, Gray-Donald K. Sewitch MJ, Johnston CC. Edgar L \& Jeans ME (1990). The prevalence of pain in hospitalized patients and resolution over six months. Pain, 50, 15-28.

American Nurses Association Council on Continuing Education (ANA, 1975). Standard for continuing education in nursing. Kansas City, Missouri: American Nurses Association.

American Nurses Association Council on Continuing Education. (ANA, 1986). Manual for accreditation as an approver of continuing education in nursing. Kansas Ciry. Missouri: American Nurses Association.

Bookbinder M, Kiss M, Coyle N, Brown MH, Gianella A \& Thaler HT (1995). Improving pain

management practices. In DB McQuire, CH Yarbro \& Ferrell BR (Eds,, 2nd edition). Cancer pain management (pp. 321-361). Boston: Jones \& Bartlett.

Camp-Sorrell D \& O'Sullivan P (1991). Effects of continuing education. Pain assessment and documentation. Cancer Nursing 14, 49-54.

Carr ECJ (1990). Postoperative pain: patients' expectations and experiences. Joumal of Advanced Nursing $15,89-100$.

Dalglish S (1990). Pain teaching project. Canadian Nurse, 86, 16-17.

Dalion JA, Bernard S, Blau W. Jobnston C, Mann JD, Germino B, Pierce S, Toomey T, Mooney D \& Carlson J (1995). Managing cancer pain: content and scope of an educational program for nurses who work in predominantly rural areas. Journal of Pain and Symptom Management 10, 3, 214-223.

Davis PS (1988). Changing nursing practice for more effective control of postoperative pain through a staff initiated educational programme. Nurse Education Today 8, 325-331.

Davis PS (1991). Teaching nurses about managing pain. Nursing Standard 5, 52, 30-33.

Degner LF. Fujii SH \& Levitt M (1982). Implementing a program to control chronic pain of malignant disease for patients in an extended care facility. Cancer Nursing 5. 263-268.

Diekmann IM \& Wassem RA (1991). A survey of nursing students' knowledge of cancer pain control. Cancer Nursing 14, 6, 314-319.

Diwan VK. Eriksson B. Sterky G \& Tomson G (1992). Randomization by group in studying the effect of drug information in primary care. International Joumal of Epidemiology 21, 1124-130.

Dols C. Forker J, Lumm M, Huff I, Johnson M, Morrell C, Prunty N, Riehl K, Sabey M \& Vail M (1995). Enhancing nurses' reliance on patients' perceptions of pain during pain assessment: a 
comparison of two educational methods. Journal of Continuing Education in Nursing 26, 5. 209213.

Ferrell BR, Grant M, Ritchey KJ, Ropchan R \& Rivera, LM (1993). The pain resource murse training program; a unique approach to pain management. Journal of Pain and Symptom Management 8. 8, 549-556.

Fielding RG \& Llewelyn SP (1987). Communication training in nursing may damage your bealth and enthusiasm: some warnings. Joumal of Advanced Nursing 12, 281-290.

Foglesong DH (1983). The impact of a staff development offering on nursing practice. Joumal of Continuing Education in Nursing 14, 6, 12-15.

Foglesong DH, Lambert J \& Emerick J (1987). Variables which influence the effect of staff development on nursing practice. Journal of Continuing Education in Nursing 18, 5, 168-171.

Francke AL \& Duivenvoorden HJ (1993). Methodologie van interventiestudies. Moeilijkheden, mogelijkheden en valkuilen. In AL Francke (Ed.). Verplegen, interveniëren en evalueren. Verpleegkundig interventie-onderzoek in de praktijk (pp.13-23). Lisse: Swets \& Zeitlinger.

Glajchen M, Blum D \& Calder K (1993). Training health care professionals in cancer pain: translating research into practice. In Proceedings of the Psycho-oncology Congress V: Psychosocial Factors in Cancer Risk and Survival (pp.397). New York.

Graffam, S (1990). Pain content in the curriculum: a survey. Nurse Educator 15, 20-23.

Grossman SA, Scheidler VR. Swedeen K, Mucenski J \&, Piantadosi S (1991). Correlation of patient and caregiver ratings of cancer pain. Journal of Pain Symptom Management 6, 2, 53-57.

Hauck S (1986). Pain: problem for the person with cancer. Cancer Nursing 9, 2, 66-76.

Herr KA \& Mobily PR (1992). Interventions related to pain. Nursing Clinics of North America 27, 2, 347368.

Itano J \& Miller CA (1990). Learning needs of Oncology Nursing Sociery members. Oncology Nursing Forum 17, 5, 697-703.

Lieb Zalon M (1993). Nurses' assessment of postoperative patients' pain. Pain, 54. 329-334.

McCaffery. M (1980). Understanding your patient's pain. Nursing, 80 (September), $26-31$.

McCaffery M (1990). Nursing approacbes to nonpharmacological pain control. International Joumal of Nursing Studies 27, 1, 1-5.

McCardle M \& Van der Wiel Y (1993). Erwaringen van wijkverpleegkundigen met het afnemen van de pijnanamnese bij patiënten met kanker in de thuissituatie. Unpublished report. Nijmegen: Hogeschool Nijmegen en Integraal Kankercentrum Oost.

McNaull FW, McLees JP, Belyea MJ \& Clipp EC (1992). A comparison of educational methods to enhance nursing performance in pain assessment. Joumal of Continuing Education in Nursing 23, 6, 267271.

Meyerink G. Tjia PF, Golbach G. Van Aalst A \& Hulshof A (1994). Verslag project 'Wenken met' verpleegkundige pijnanamnese'. Unpublished report. Utrecht: Integraal Kankercentrum MiddenNederland.

Myers J (1985). Cancer pain: assessment of nurses' knowledge and attitudes. Oncology Nursing Forum 12, 4, 62-66.

Paice JA. Mahon SM \& Faut-Callahan, M (1991). Factors associated with adequate pain control in hospitalized postsurgical patients diagnosed with cancer. Cancer Nursing 14, 6, 298-305.

Rothman KJ (1986). Modem epidemiology. Boston, Massachusetts: Little, Brown and Company.

Sofaer B (1984). The effect of focused education for nursing teams on postoperative pain of patients. Unpublished PhD-thesis. Edinburgh: University of Ediuburgh.

Stevens, J (1986). Applied multivariate statistics for the social scientists. Hillsdale. New Yersey. London: Lawrence Erlbaum Associates Publishers.

Struthers CL \& Jeffrey J (1993). Nurses' knowledge and assessment of postoperative pain before and after a continuing education session. In Proceedings of the 7th World Congress on Pain (pp.397). Paris: IASP.

Verpleegkundig Wetenschappelijke Raad/Centraal Begeleidingsorgaan voor de Intercollegiale Toetsing (VWR/CBO, 1994). Consensus Verpleegkunde bij Pijn. Utrecht: CBO. 
Waddell DL (1990). The effects of continuing education on nursing practice: a metu-analysis. Unpuhlished $\mathrm{PhD}$-thesis. Georgia: University of Georgia.

Westfall LK \& Speedie SM (1981). The effects of inservice education provided by consultant pharmacists on the behavior of nurses in long-term care facilities. Drug Intelligence and Clinical Pharmacy IS. 777-781.

Weissman DE, Gutmann M \& Dahl JL (1991). Physician cancer pain education: a repor from the Wisconsin Cancer Pain Initiative. Journal of Pain and Symptom Management 6, 7, 445-448.

Weissman DE Dahl JL \& Beasly JW (1993). The Cancer Pain Role Model Program of the Wisconsin Cancer Pain Initiative. Joumal of Pain and Symptom Management 8, 1. 29-35. 
CHAPTER 3 Qualitative needs assessment prior to

a continuing education program

on pain assessment and management

This chapter is an adapted version of the article 'Qualitative needs assessment prior to a continuing education program'.

Published in 1996 in the Journal of Continuing Education in Nursing 27, 1, 34-41.

Authors: AL Francke, B Garssen, H Huijer Abu-Saad \& M Grypdonck. 


\section{Qualitative needs assessment prior to a continuing education program on pain assessment and management}

\section{Summary}

A needs assessment study was carried out prior to a CE program on pain assessment and management. This study consisted of three parts: 1) participant observations on cancer wards, 2) interviews with surgical cancer nurses and 3) interviews with surgical breast cancer patients. It was found that surgical cancer nurses usually did not assess pain systematically and thoroughly, gave pain medication irregularly, were sometimes unaware of the effectiveness of certain nonpharmacological pain interventions and often felt powerless. In addition, it was established that surgical breast cancer patients were inhibited in expressing pain. This inhibition was related to patients' preconceptions concerning pain and analgesics, interactions with nurses, insecurity and lack of assertiveness.

The qualitative methods used in the needs assessment study proved to be useful for exploring CE needs and for bridging the gap between research, education and nursing practice.

\section{Introduction}

Qualitative research methods are appropriate for revealing personal perspectives and experiences (Blumer, 1969; Chenitz \& Swanson, 1986; Strauss \& Corbin, 1990). In addition, they can provide realistic descriptions of care providers' worlds (Glaser \& Strauss, 1967; Van Zuuren, 1995). These characteristics of qualitative methods may be relevant in assessing nurses' $\mathrm{CE}$ needs. Still, conducting a qualitative needs assessment is rather uncommon in $\mathrm{CE}$ research. Therefore, this chapter discusses methods and findings. as well as the value of a qualitative needs assessment study.

The methods used in this study do not belong to one particular qualitative 'school'. They were based, however, to a large extent on approaches described by prominent qualitative methodologists like Lincoln \& Guba (1985 and 1986), Miles and Huberman (1984) and Strauss et al. (Glaser \& Strauss, 1967; Strauss, 1987; Strauss \& Corbin, 1990). What these approaches have in common is that they all aim to explore and understand the nature of human phenomena. The position that a researcher must be open to new insights and not be restricted by narrowly formulated research questions, is also typical for these approaches. Open, broad research questions are narrowed down during a cyclic research process in which data collection and analysis constantly alternate. This cyclic, open process enables the researcher to gain insights grounded in social reality (Bosch, 1990; Chenitz \& Swanson, 1986; Miles \& Huberman, 1984; Strauss, 1987; Wester, 1991). Often, in keeping with the openness of the research, only an overall view of existent literature is taken prior to data collection. In later research phases a more intensive literature study can be carried out to validate or compare research findings.

Decisions about the selection of cases or research subjects are usually made on the basis of insights derived from previous research phases (Chenilz \& Swanson, 1986). This is related to the fact that qualitative research has to provide a valid description of human phenomena in specific settings, rather than statistical inferences. 
In the next sections we will clarify the use of qualitative methods in the needs assessment study.

\section{Participant observations}

Research question. The first phase of the needs assessment study consisted of participant observations on cancer wards. The initial, open research question was formulated as follows:

How do hospital nurses interact with cancer patients with pain, and how are these interactions experienced by both parties?

Sample, data collection and analysis. The observation phase consisted of forty-four days of observation in two medical and surgical oncological wards ${ }^{3}$ spread over four general hospitals. The choice of the hospitals was made on a convenience basis. Entry to the hospitals was gained by contacting nursing directors and head nurses.

The researcher (A.L.F.), who has a nursing and sociology background, observed in the role of a nurse's aid. The ward nurses and the patients were informed about the general research aims, but not about specific details and interests.

The cyclic process of qualitative data collection and analysis was clearly manifest in the observation periods. When the researcher saw or heard anything relevant, she retired for a moment to a quiet spot and made short observation notes. The observations were written out in more detail as soon as possible. This material was read through many times and important fragments were assigned code words or category names (=classifications of code words) directly based on the content of the fragments (Bosch, 1990; Miles \& Huberman, 1984; Strauss \& Corbin, 1990). Examples of categories are: 'pain assessments', 'provision of information' and 'emotional support'. Subsequently, text fragments with the same code word or category name were ordered and brought together, again intensively studied and interpreted. Conclusions from interim analyses were modified or verified in subsequent observations on the same or another ward.

At the conclusion of observations on a particular ward, the researcher wrote an interim report based on the ordered, analyzed observation notes. This report was presented to the nurses observed, after which they gave feedback on whether they agreed with the analyses. In addition, feedback on interim analyses was received from several fellow-researchers, pain experts and program instructors. Such feedback procedures are appropriate to increase the quality of the analyses (Lincoln \& Guba, 1985 and 1986: Miles \& Huberman, 1984; Wester, 1991).

Findings. The nurses observed seemed very concerned with cancer patients in pain. They strove, within the limits of their competence, to provide pain relief. However, nurses did not assess pain regularly and thoroughly. They sometimes did ask a patient about pain,

3. Of these four wards, none would be involved in the controlled intervention study (Chapter 5-8). The advantage was that in this way the 'experimental manipulation' in the intervention study was not disturbed by previous interactions between researcher and nurses during the observation periods. 
but usually did not go more deeply into it. For instance, they did not ask how the patient experienced his pain or about pain characteristics. As a result, in most cases, patients' verbal pain expression was limited. The observations also revealed that the intervals at which analgesics were given were often long and irregular; even when patients were in severe pain. Furthermore, it appeared that certain nonpharmacological pain interventions, like massage, relaxation and distraction, were rarely used. These findings would be confirmed and completed in the interviews with nurses and patients which took place after the observation phase (see sections 'Nurse interviews' and 'Patient interviews').

During the observation periods it also appeared that the surgical cancer nurses had participated less in educational activities on pain-related topics than nurses on medical cancer wards. CE needs concerning pain assessment and management seemed most apparent in surgical cancer nurses and therefore it was decided to limit attention to the surgical cancer setting in the next phases.

\section{Nurse interviews}

Research questions. The subsequent interviews had to shed more light on gaps and needs with respect to nurses' pain assessments and interventions. The initial research question (see section 'Participant observation') was therefore narrowed down as follows:

How do surgical cancer nurses assess pain?

What interventions do nurses use in surgical cancer patients with pain?

What $C E$ needs do surgical cancer nurses identify with respect to their pain assessments and interventions?

Sample, data collection and analysis. Twenty-five surgical cancer nurses ${ }^{4}$, who had all completed initial nursing education, were interviewed (background characteristics are given in Table 3.1). Indirect recruitment of nurse interviewees was done by nursing directors and head nurses ${ }^{5}$. The interviews were conducted in a separate room on the ward and lasted one to one and a half hours ${ }^{6}$.

The open-ended interview questions directly related to the research questions, were guided by means of an interview schedule. Important interview questions were: "What do you think is of utmost importance in the management of pain of surgical cancer patients?", "What methods or interventions do you apply in daily practice for relieving pain in surgical cancer patients?" and "If you had to develop a CE program on pain management, what type of topics would you pay attention to?".

It was decided to stop data collection after twenty-five nurse interviews because no

4 Three of these nurses were working on a ward which would be involved in the controlled intervention study described in the Chapters 6-9.

3. Although they were asked not to do so, nursing directors and head nurses may bave recruited nurses known for their experise. This may have biased the research findings somewhat in a positive direction.

${ }^{6}$. Informed consent was obcained prior to each interview and anonymity and confidentiality were guaranteed. 
new relevant data seemed to emerge in the last interviews.

All interviews were recorded on cassette tapes and later transcribed. The transcriptions were carefully studied, coded and analyzed in a way comparable to the procedures used for the observation material (see section 'Participant observations').

\section{Findings}

Pain assessments. The nurses interviewed indicated that they considered the assessment of pain a very important nursing task. However, a comprehensive approach in which the charted pain problem forms the basis for the selection of nursing interventions, seemed to be lacking (see Camp-Sorrell \& O'Sullivan, 1991; Dalton, 1989; Paice et al., 1991). This is illustrated by the fact that among all interviewees, taking a pain history from patients was not the usual practice.

"Well, yes, of course, we do talk about a wound which hurts and about a drain which causes pain. But not in such a way that a complete pain history is taken". (N6, 26 years, ward nurse)

Some nurses said they were eager to be taught about new pain assessment methods and to test whether they were useful in practice. Interviewees also indicated that they would like to learn more about the patients' pain experience by means of continuing education.

"How the pain feels, what it is like. For if you have insight into this, you can respond to it in a better way". (N8, 32 years, team leader)

Others expressed less interest in learning about pain and the assessment of pain. These nurses found extensive assessment of pain in surgical cancer patients a bit 'overdone'. They considered the pain caused by surgery 'normal' and, in principle, easy to identify. This attitude could explain the often rather superficial and irregular questions nurses asked when assessing pain, also observed in the previous observation periods.

Provision of information. Structured information attuned to the patient's needs, may reduce anxiety and distress, with the result that patients may experience less postsurgical pain (e.g. Devine \& Cook, 1986; Grypdonck, 1989; Hathaway, 1986). According to the interviewees, information about procedures and treatment was frequently provided. However, sensory information about what a patient will feel, hear or see, seemed to be sparse. Only one interviewee expressed that she gave that kind of information, as a result of personal experiences.

"Recently I had a gastroscopy. Of course I knew that it was a very unpleasant examination. Now that it's all behind me, I'm able to inform patients in a much better way than before (...). I would say: Some air is blown in and you get an unpleasant feeling, as if your stomach will burst". (N18, 50 years, head nurse)

It also appeared to be rather exceptional that a patient got information on how to prevent (worse) pain. The few nurses who said that they did pay attention to this, mostly did this by telling a patient which position was probably the most comfortable one.

\footnotetext{
?. N6 $=$ respondent number, 26 years $=$ age, ward nurse $=$ function .
} 
"If someone is in pain, I sometimes tell him: "You could try to lie like this or that'. Or I tell that they should support their wounds properly when they change their position in bed". (N4, 32 years, ward nurse)

Emotional support. Nurses indicated that a patient's pain sometimes seemed to ease in their presence, just by their 'being there for someone'. For this reason, they considered emotional support a very important part of taking care of surgical cancer patients in pain. However, they also stated that they sometimes felt insecure about how to care for patients. Nurses said they often did not know what to say, especially in cases of severe pain. The feeling of having no immediate solution was difficult to deal with, and in these situations, nurses often felt powerless (see Clements \& Cummings, 1991; Fagerhaugh \& Strauss, 1977).

With respect to emotional support, some also spoke of their difficulty in achieving the right balance between identifying with and distancing from the patient:

"Then you think to yourself: Will this patient ever get better; will she actually pick up? And then you think of it at home as well. At least, I do. Then you think, I wonder if she slept well, or something like that. Sometimes I think that I definitely take things home a little too often". (N6, 26 years, ward nurse)

Nurses indicated that they therefore considered it worthwhile that attention be paid in CE to nurses' personal feelings and experiences with respect to supporting patients.

Promotion of autonomy. Some nurses reported that they stimulated patients' autonomy by actively involving them in the caring process.

"And then I ask: 'What can you do yourself, for I will take care of the rest. And then tomorrow we'll see if you can do even more. And if not, that's no problem, soon you will be able to do it". (N15, 52 years, team leader)

Patients may experience a sense of self-control when autonomy is promoted. As a result, they may have less fear and pain (Pool, 1983; Shade, 1992). However, the majority of the nurses interviewed did not associate autonomy promotion with pain management.

Massage, relaxation and distraction. Massaging patients to promoting relaxation and pain relief appeared to be fairly unconventional in the Dutch surgical cancer setting. Almost none of the nurses stated that they ever used massage in any other situations than for a painful neck or for preventing decubitus.

Although nurses reported that they sometimes distracted patients by "having a chat", structured distraction or relaxation techniques were also rarely used (see Dalton, 1989, McCaffery, 1990; Schuurmans et al., 1993). Most nurses hardly seemed to realize that pain could be alleviated by such interventions.

"I don't think we are very aware that there are other methods besides medicines and such. (...) I don't think hospital nurses are very familiar with alternatives". (N3, 24 years, ward nurse) 
Cold, heat and comfort measures. Nurses indicated that on rare occasions they made use of cold (e.g. in case of phlebitis as a result of infusion) or heat treatments (particularly in case of menstrual complaints). However, they did not often think about the possibility of such techniques.

"We once used an ice packing for swellings. And when someone's arm hurts a lot, in case of phlebitis, I also sometimes use cold treatment. And it really works then. But then again, you know how it goes, it often doesn't occur to you". (N8, 32 years, team leader)

Environmental and physical comfort measures, such as removing disturbing noises or making someone feel comfortable in bed (see VWR/CBO, 1994), were also mentioned by some interviewees as being an important part of nursing care in case of pain. However, others seemed to be unaware of the importance of such measures for patients in pain.

Pharmacological pain management. Pain experts (e.g. Acute Pain Management Guideline Panel, 1992; McCaffery \& Beebe, 1989) have stressed that frequent and regular use of pain medication is necessary for optimal postsurgical pain relief. For this reason, analgesia scheduled around the clock is preferable. Still, the nurses interviewed indicated that on their ward 'as needed' prescriptions were most usual. Although several nurses emphasized the advantages of scheduled analgesia, they expressed a rather passive attitude towards the physicians' pain policy (see Clements \& Cummings, 1991; Ferrell et al., 1991):

"And we just do what we are told to do, but we still think it has to be administered every four to six hours". (N13, 32 years, head nurse)

Even when instructed to carry out a policy they did not agree with, nurses felt compelled to stick to it. Probably due to a rather dependant attitude towards physicians, ideas on pain management were rarely discussed:

"But we are instructed by the anaesthetist: "Morphine as needed, every six hours".

And then if it is needed four hours later, you cannot make a change on your own authority". (N13, 32 years, head nurse)

In addition, nurses mentioned certain patients' preconceptions with regards to addiction that also stand in the way of adequate pain relief:

"They are afraid of getting addicted: "Because, well, these medications are not really good, are they?".. The patients always say that: "Medicines are not good". (N8, 32 year, team leader)

Interviewees themselves did not express misconceptions concerning analgesics ${ }^{8}$. Still, some said that they often observed deficiencies in colleagues' knowledge about sideeffects. In particular, the risks of addiction and respiratory depression would be overestimated (see Ferrell et al, 1991; Fothergill-Bourbonnais \& Wilson-Barnett, 1992; McCaffery et al., 1990; McCaffery \& Ferrell, 1992).

\footnotetext{
*. Perbaps the nurses interviewed had more expertise regarding pain naragement than most of their colleagues. See note 5 .
} 
Table 3.1. Background characteristics of murses

\begin{tabular}{|c|c|c|}
\hline \multicolumn{2}{|c|}{ Background characteristics } & \multirow{2}{*}{$\frac{n}{20}$} \\
\hline Sex & female & \\
\hline & male & 5 \\
\hline \multirow[t]{2}{*}{ Function } & head nurse/ team leader & 9 \\
\hline & nurse & 16 \\
\hline \multirow[t]{2}{*}{ Education level } & $\mathrm{HBO}^{\prime \prime}$ & 13 \\
\hline & $\mathrm{MBO}^{\prime \prime}$ & 12 \\
\hline \multirow[t]{3}{*}{ Years qualified } & $0-5$ & 8 \\
\hline & $6-10$ & 6 \\
\hline & $>10$ & 11 \\
\hline \multirow[t]{4}{*}{ Age in years } & $21-30$ & 10 \\
\hline & $31-40$ & 11 \\
\hline & $41-50$ & 3 \\
\hline & $>50$ & 1 \\
\hline \multirow[t]{2}{*}{ Caucasian } & yes & 24 \\
\hline & non & $!$ \\
\hline \multirow[t]{2}{*}{ Hospital setting } & university & 13 \\
\hline & non-universily & 12 \\
\hline
\end{tabular}

" $\mathrm{HBO}=$ Dutch bigher professional education level, $M B O=$ Dutch secondary professional education level.
Table 3.2. Background characteristics of patients

\begin{tabular}{|ll|l|}
\hline Hackground characteristics & f \\
\hline Sex & female & 26 \\
Age in years & $31-40$ & 0 \\
& $41-50$ & 2 \\
& $51-60$ & 6 \\
& $61-70$ & 12 \\
& $>70$ & 4 \\
Type of surgery & mastectomy & 17 \\
Caucasion & lumpectomy & 9 \\
& yes & 26 \\
Hospital setting & no & 0 \\
& university & 11 \\
& non-university & 14 \\
& cancer clinic & 1 \\
\hline
\end{tabular}

\section{Patient interviews}

Research questions. Interviews with surgical breast cancer patients were conducted to gain insight into nurses' $\mathrm{CE}$ needs from a patient perspective. The initial patient interviews focused on patients' experiences with respect to nurses' assessment and management of pain in general. It was striking, however, that patients often revealed that they hardly told anybody in the hospital about their pain. Related to this finding, our definitive research questions for the patient interviews were formulated as follows.

How do female breast cancer patients perceive their postoperative pain?

Do female breast cancer patients express their postoperative pain during their hospital stay?

How do hospital nurses respond to the patients' postoperative pain? 


\section{Chapter 3}

Sample, data collection and analysis. A total of twenty-six breast cancer patients ${ }^{9}$ were interviewed (for background characteristics, see Table 3.2). Patients with breast cancer surgery were chosen because breast cancer is highly prevalent and its surgical treatment often involves pain (Daut \& Cleeland, 1982). Interviews were conducted within six months after surgery ${ }^{10}$ since extensive interviews shortly after the operation would be quite taxing. Eighteen of the twenty-six patients were recruited by surgeons, eight by advertising in journals.

The patient interviews lasted one to two hours and were conducted at the patients' homes $^{\prime \prime}$. Data collection was halted after twenty-six patient interviews, because no new, relevant data emerged in the last interviews (Strauss \& Corbin, 1990).

Important questions from the interview schedule were: "What did the pain after the operation mean to you?", "Did you express this pain to the nurses?", "How do you perceive pain caused by surgery?" and "Was it possible to ask nurses questions about pain or pain alleviation?".

The recorded interviews were transcribed and analyzed in the same way as described within the framework of the participant observations (see before).

\section{Findings}

Inhibition in expression of pain. Almost all patients said that they had not expressed postoperative pain and had not asked for pain alleviation, whereas they were actually suffering from pain ${ }^{12}$. It appeared that this inhibition in expressing pain was related to several factors, such as patients' preconceptions of postoperative pain and analgesics, interactions with nurses and insecurity and lack of assertiveness. In the following sections these factors will be elaborated.

Preconceptions of postoperative pain and analgesics. Most patients only expressed pain if their suffering was very severe. As the pain caused by breast cancer surgery was often less intense than certain pains experienced in the past, patients thought they had to endure the pain without complaining:

"Expressing pain isn't necessary when the pain is not so severe that the tears come to your eyes. I have experienced such pain in the past, pain that makes you really

- About a quarter of these patients had been hospitalized on one of the wards of the nurse interviewees.

19. A six-month upper limit seemed realistic in light of existent findings on recall of events during hospitalization (Cannell et al., 1965).

11. Informed consent was obtained from all patients.

12. Severai nursing and medical studies also pointed to the phenomenon of inhibition in expressing pain (e.g. Carr. 1990; Juhl et al., 1993; Ward et al., 1993; Ward \& Gatwood. 1994). In addition, culrural anthropology studies (e.g., Madjar, 1985: Shuter \& Miller. 1982: Zhorowski, 1969) focused on the differences in pain expression between people with a different cultural and ethnic background. Probably as a result of the fact that nearly all nurses and patients interviewed had a Dutch, caucasian background (see Tables 3.1 and 3.2 ) these differences were not apparent in the needs assessment study presented. 
cry (...) But I could endure this pain". (P14, 60 years, lumpectomy) ${ }^{13}$

Many patients said that they had expected postoperative pain and that in their opinion this kind of pain was inevitable. This expectation resulted in lack of pain expression:

"It's all part of the game. I think that goes for any operation, it will result in pain.

So, yes, you put up with it". (P23, 39 years, mastectomy)

Furthermore, a great number of the patients appeared to be prejudiced against analgesics and were afraid to become addicted. In addition, they were afraid that a time would come with a more urgent need for painkillers and "then they won't have an effect any more". Some patients also thought that pain medication was very bad for their health, and spoke about 'rubbish' or 'poison'. This made them reluctant to express their pain and to ask for analgesics.

Interactions with nurses. In most cases nurses had not intervened to change patients' preconceptions regarding analgesics. Based on patients' remarks it even seemed as if nurses had reinforced these preconceptions, for instance, by reacting as if postoperative pain was 'normal' and therefore did not require alleviation.

Nearly all patients said that the first day and night after the operation nurses had occasionally asked whether they were in pain. After that, patients got the impression that it was quite unusual to pay attention to pain:

"But the third evening the nurses thought it wouldn't be right to ask me, do you need a pain-killer? Then nobody asks do you need anything". (P4, 51 years, mastectomy)

Whether patients expressed their feelings of pain to nurses also appeared to be dependent on the limited confidence they had in nurses' armory of pain interventions. Some of the patients said that they had the impression that pharmacological interventions were seen by nurses as the only alternatives, and this had also inhibited them in expressing their pain:

"Talk about it? No, I didn't, because, well I mean, what they say is, are you in pain? Would you like a painkiller?" (P10, 55 years, mastectomy)

Insecurity and lack of assertiveness. Another reason for not expressing pain was that patients were afraid of being considered 'annoying' by nurses or doctors. Patients said that they did not mention their pain because they had the impression that the nurses were 100 busy to pay attention to them; they had not wanted to take up nurses' time. Therefore, most patients interviewed had pretended to feel better than they actually did. Patients often expressed their pain only when they were explicitly asked to do so, and even then they were afraid that nurses or doctors would think negatively about their expressing pain:

"He said, how are you? Well, what am I supposed to say then? I gave him a straight answer: It's very painful. And at the same time I thought, boy, am I a nuisance". (P19, 60 years, mastectomy)

\footnotetext{
${ }^{13}$. P16 = respondent number, 60 years $=$ age, lumpectomy $=$ type of surgery.
} 


\section{Chapter 3}

\section{Translation of the findings into the CE program}

There were meetings between the researcher and the program instructor after each observation period. Findings and their implications for the program were discussed during these meetings. It became apparent that the $\mathrm{CE}$ program had to focus on:

- characteristics of pain and the assessment of pain,

- psychosocial interventions (provision of information, emotional support and promotion of autonomy),

- physical and relaxation interventions (use of massage, relaxation, distraction, physical and environmental comfort measures, cold and heat) and

pharmacological pain management.

In addition, it became apparent that the program had to focus on broadening of knowledge and skills, as well as on the exchange of (learning) experiences, personal attitudes and feelings (see Chapter 4). The latter would offer nurses an opportunity to discuss with colleagues how they dealt with the sometimes stressing aspects of caring for patients in pain.

The qualitative needs assessment also functioned as a main point of departure for the homework literature file. Findings from the nurse and patient interviews were integrated in a booklet about pain problems and interventions (Francke, 1992) and in an article about patients' inhibition in expressing pain (Theeuwen \& Francke, 1992). Both publications were part of the homework file, and as the content of these publications was directly derived from nursing practice, participants received recognizable information in this way.

\section{Discussion}

The foregoing illustrates how qualitative research can contribute to the documentation of CE needs and the development of a program plan. In particular, unexpected or less immediate needs, may more readily emerge by means of qualitative research. For example, it is questionable whether asking nurses in a questionnaire about their CE needs would result in a topic such as 'how to deal with one's own feelings in caring for patients in pain'. Qualitative methods leave more room for the personal experiences of research subjects. Therefore, qualitative needs assessments can give researchers and instructors a realistic, life-picture of the professionals" working world. This helps to avoid unrealistic CE programs developed by people who could be characterized as 'ivory tower scientists'. The use of qualitative methods might narrow the gap between research, education and practice, so often felt by nurses and other health professionals.

Another characteristic of qualitative approaches is that they are appropriate for research in new areas. Not as much research was conducted in the area of nurses' pain assessment and management during the period of the needs assessment (1989-1990) as there is at present. As a result, no Dutch-languaged quantitative response formats existed which could be used. In such cases the use of qualitative methods to obtain valid descriptions offers the best alternative (Van Dongen-Melman, 1995; Smaling, 1996).

In addition, qualitative methods have practical and ethical advantages. Research subjects usually like to express their opinions or experiences in a more or less natural 
setting. The researcher does not have to 'chase' nurses or patients in order to make them fill in questionnaires which -in their eyes- are boring or irrelevant (Van Zuuren, 1995).

On the other hand, qualitative methods have some limitations and disadvantages. It is better to use structured instruments (provided that such instruments exist and that they are valid and reliable) when one wants to know the exact frequencies of certain CE needs, or the precise level of knowledge or attitudes. Furthermore, it must be realized that qualitative research strategies are time consuming; often even more so than quantitative strategies. To illustrate the extensive time involved in the needs assessment study, the collection of data took 400 to 450 hours. The data analysis required four to five times as long. If, for one reason or another, larger samples have to be investigated (e.g. for calculating statistical significance), or a study has to be performed in a short time span, using qualitative methods may not be realistic. However, the difference between CE programs that limp along with apathetic participation and those that are vibrant with activity, usually can be traced to how well learning needs have been assessed (Rosof $\&$ Saslaw, 1986). In this context, the investment of a qualitative needs assessment study may be justified.

\section{References}

Acute Pain Management Guideline Panel (1992). Acute pain management: operarive or medical procedures and trauna. Clinical practice guideline. AHCPR Pub.: No.92-0032. Rockville, MD: Agency for Health Care Policy and Research. Public Health Service, U.S. Deparment of Health and Human Services.

Blumer H (1969). Symbolic interocrionism: perspective and method. Englewood Cliffs: Prentice Hall.

Bosch CFM (1990), De Grounded Theory Benadering in een onderzoek op psycho-geriatrische afdelingen. ln AL Francke (Ed.), Kuralitarief Onderoek in de Verpleegkunde (pp.59-73). Lisse: Swets \& Zeitlinger.

Camp-Sorrell LD \& O'Sullivan PS (1991). Effects of continuing education: pain assessment and documentation. Cancer Nursing 14, 1, 49-54.

Cannell CF. Fisher G \& Bakker T (1965). Reporting of hospitalization in the health interview study. In Vital and Health Statistics, Series 2, 6, U.S.: Department of Health, Education and Welfare.

Carr ECJ (1990). Postoperative pain: patients' expectations and experiences. Journal of Advanced Nursing, IS. $89-100$.

Chenitz WC \& Swanson JM (1986). From practice to grounded theory. Qualitative research in nursing. California: Addison-Wesley Publishing Company.

Clements S \& Cummings S (1991). Helplessuess and powerlessness: caring for patients in pain. Holistic Nursing Practice 6, 1, 76-85.

Dalion JA (1989). Nurses' perceptions of their pain assessment skills, pain management practices, and attitudes toward pain. Oncology Nursing Forum 16, 2, 225-231.

Daut RL \& Cleeland CS (1982). The prevalence and severity of pain in cancer. Cancer, 50, 1913-1918.

Devine EC \& Cook TD (1986). Clinical and cost-saving effects of psycho-educational interventions with surgical patients: a meta-analysis. Research in Nursing and Healih 9, 89-105.

Dongen-Melman JEWM van (1995). On surviving childhood cancer. Late psychosocial consequences for parients, parents and siblings. Alblasserdam: Haveka BV.

Fagerhaugh SY \& Strauss AL (1977). Politics of pain management: staff-patient interaction. Califomia: Addison-Wesley Publishing Company.

Ferrell BR, Eberts MT, McCaffery M \& Grant M (1991). Clinical decision-making and pain. Cancer Nursing 14, 6, 289-297.

Fothergill-Bourbonnais F \& Wilson-Barnett J (1992). A comparative study of intensive therapy unit and 


\section{Chapter 3}

hospice nurses' knowledge on pain management. Journal of Advanced Nursing, 17, 362-372.

Francke AL (1992). Pijn als verpleegprobleem. Dwingeloo: Kavanah.

Glaser BG \& Strauss AL (1967). Awareness of dying. Chicago: Aldine Publishing Company.

Grypdonck $M$ (1989). Voorbereiding van volwassen patiënten op chirurgische ingrepen. Verpleegkunde. Nederlands-Vlaams Wetenschappelijk Tijdschrift voor Verpleegkındigen 3, 4, 171-186.

Hathaway D (1986). Effect of preoperative instruction on post-operative outcomes: a meta-analysis. Nursing Research 35, 269-275.

Juhl IU, Christensen BV, Bũlow HH, Wilbek H, Dreijer NC \& Egelund B (1993). Postoperative pain relief, from the patients' and the nurses' point of view. Acta Anaesthesiologica Scandinavica, 37, 404 409.

Lincoln YS \& Guba EG (1985). Nanuralistic Inquiny. Newbury Park, London, New Delhi: Sage Publications.

Lincoln YS \& Guba EG (1986). But is it rigorous? Trustworthiness and authenticity in naturalistic evaluation, In D.D Williams (Ed.). Naturalistic evaluation, new directions for program ewaluation, (pp.73-84). San-Francisco: Yossey-Bass.

Madjar I (1985). Pain and the surgical patient: a cross-cultural perspective. Australian Joumal of Advanced Nursing 2, 2, 29-33.

McCaffery M \& Beebe A (1989). Pain. Clinical Manual for Nursing Practice. St. Louis-BaltimorePhiladelphia-Toronto: C.V. Mosby Company.

McCaffery M. Ferrell BR, O'Neil Page E, Lester M \& Ferrell B (1990). Nurses knowledge of opiate analgesics and addiction. Cancer Nursing 13, 1, 21-27.

McCaffery M (1990). Nursing approaches to nompharmacological pain control. International Joumal of Nursing Studies 27, 1, 1-5.

McCaffery M \& Ferrell BR (1992). Opioid analgesics. Nurses' knowledge of doses and psychological dependence. Joumal of Nursing Staff Development, March/April, 77-85.

Miles MB \& Huberman AM (1984). Qualitative data analysis. A sourcebook of new methods. Beverly Hills London New Delhi: Sage Publications.

Pool JJ (1983). Sociaal-therapeutisch gedrag van verpleegkundigen. PhD-thesis. Amsterdam: Free University.

Paice JA, Mahon SM \& Faut-Callahan M (1991). Factors associated with adequate pain control in hospitalized postsurgical patients diagnosed with cancer. Cancer Nursing 14, 6. 298-305.

Rosof AB \& Saslaw KL (1986). Needs assessment. In AB Rosof \& WC Felch (Eds.), Continuing medical education (pp.17-30). New York, Westpor,, Connecticut, London: Praeger.

Schuurmans J, Wulferink A \& Boer H (1993). Pijn bij kanker: opvattingen van verpleegkundigen. Tijdschrift voor Ziekenverpleging, 3, 97-100.

Shade P (1992). Patient-controlled analgesia: can client education improve outcomes? Joumal of Advanced Nursing 17, 408-413.

Shuter R \& Miller FJ (1982). An exploratory study of pain expression among blacks and whites. International Joumal of Intercultural Relations, 6, 281-290.

Smaling A (1996). De relevantie van de argumentatietheorie voor kwalitatief onderzoek. Kwalon. Tijdschrift voor Kwalitaticf Onderzoek in Nederland 1, 1, 4-8

Strauss AL (1987). Qualitative analysis for social scientists. Cambridge: Cambridge University Press.

Strauss AL, \& Cortin J (1990). Basics of qualitative research. Grounded theory procedures and techniques. Newbury Park, London, New Delhi: Sage Publications.

Theeuwen I \& Francke AL (1992). Geremdheid in het uiten van pijn. Verpleegkande. Nederlands-Vlaams Werenschappelijk Tijdschrift voor Verpleegkundigen 6, 2, 75-84.

Verpleegkundig Wetenschappelijke Riad/Centraal Begeleidingsorgaan voor de Intercollegiale Toetsing (VWR/CBO, 1994). Consensus Verpleegkunde bij Pijn. Utrecht: CBO.

Ward SE. Goldberg N, Miller-McCauley V, Mueller C, Nolan A, Pawlik-Plank D. Robbins A. Stormoen D \& Weissman DE (1993). Patient-related barriers to management of cancer pain. Pain, 52, 319-324.

Ward S \& Garwood J (1994). Concems about reporting pain and using antigesics. A comparison of persons with and without cancer. Cancer Nursing 17, 3,200-206. 
Wester F (1991). Strategieen wor kwalitatief onderzoek. Muiderberg: Coutinho.

Zborowski M (1969). People in pain. San Francisco: Jossey-Bass.

Zuuren FJ van (1995). Kwalitatief onderzoek. Het belang van een kwalitatieve benadering bij onderzoek in de sociale gezondheidszorg. Tijdschrift woor Sociale Gezondheidszorg 73, 5, 315-321. 
CHAPTER 4 Confluent Education;

the educational method of the program

This chapter is an adapted version of the article 'Confluent education; an integrative approach for nursing (continuing) education'.

Published in 1994 in the Journal of Advanced Nursing 19, 2, 354-361.

Authors: AL Francke \& MJM Erkens. 


\section{Confluent Education; the educational method of the program}

\section{Summary}

In this chapter 'Confluent Education', the educational method used in the CE program on pain assessment and management, is presented. First, attention is focused on the general characteristics of Confluent Education. Within this scope the four overlapping learning domains in Confluent Education are discussed: the domain of creating readiness to learn, the cognitive domain, the affective domain and the domain of taking responsibility for what is learned. In addition, attention is paid to the importance of awareness and the processes of (dis-)identification on the part of instructors and participants. Finally, the way in which Confluent Education can take place in practice is illustrated by an 'overalllook' at the sessions of the CE program on pain assessment and management.

\section{Introduction}

Prior to the 1960's, traditional curricula often placed emphasis exclusively on broadening students' knowledge. Some later educational approaches, often described as affective or experiential, shifted emphasis almost entirely toward the exchange of personal feelings, experiences and attitudes with respect to program themes.

In reaction to this imbalance, educators like Brown et al. (1975, 1976, 1981 and 1990) and Castillo (1974) emphasized the natural relationship between cognition and affect. These educators worked out the principles of Confluent Education, a method strongly influenced by psychotherapeutical approaches belonging to the so-called third force psychology (e.g. Maslow, 1968). The influence of Gestalt therapy (Perls, 1970) is probably the most pronounced, as its main feature, the promotion of 'awareness' to enhance personal growth, is also prominent in this educational method.

Confluent education was used in the CE program on pain assessment and management (see Appendix I). This method was chosen because it was assumed that the learning process would be enhanced if attention were paid to both affect and cognition (Alexander, 1990: Boekaerts, 1987; Gerards, 1987). The confluence between affective and cognitive learning seemed especially important in this CE program on pain. After all, a nurse's knowledge, experience and feelings will all determine the quality of the nurse's pain assessment and management. If participants were only trained in cognitive aspects (e.g. broadening of knowledge about pain assessment instruments or about pain medication), they might possibly in practice ignore the interpersonal processes between themselves and patients. They might also possibly ignore the unique process which occurs in themselves and in each patient. In these cases, nurses would not learn to value patients' personal feelings and perceptions related to pain. If, on the other hand, attention was only paid to the affective domain (e.g. the feelings nurses have in caring for patients in severe pain), nurses might develop a narrow view that pays insufficient attention to the physical needs of patients. 
Previous studies concerning confluent education focused, for instance, on health education (Ross Paulk, 1985), or education of university students (Nattiv, 1986). Unfortunately, within the field of nursing CE, experimental studies that compare the efficacy of the Confluent Education method with, for instance, purely cognitive approaches are lacking. However, as the reader may wish more insight into the theoretical basis of the pain CE program, this chapter discusses Confluent Education's basic characteristics and premises.

\section{Characteristics of Confluent Education}

Learning domains. The first main characteristic of Confluent Education, as demonstrated in its name, is the 'flowing together' of four overlapping learning domains (Brown et al., 1975, 1976, 1981 and 1990; Castillo, 1974):

- the domain of readiness;

- the cognitive domain (mind);

- the affective domain (feelings);

- the domain of responsibility.

Figure 4.1: The four overlapping learning domains (Castillo, 1974).

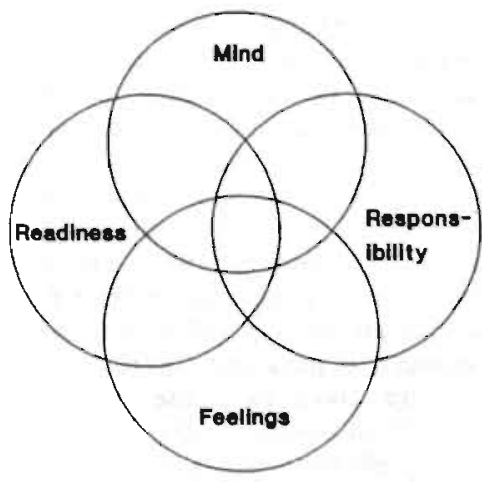

Readiness refers to the student's awareness of learning needs and to openness and willingness to learn. To achieve readiness, the program instructor has to create an environment in which the student feels safe, and has the idea that one will not be coerced to learn in an undesired manner. This is important in every learning process, but especially in processes involving affective learning. 
The cognitive domain includes the activities of the mind, the functioning of the intellect: what an individual learns and the various intellectual processes of learning.

The affective domain deals with how students feel about learning, how they feel as they learn and how they feel after they have learned. In addition, the affective domain refers to students' personal feelings, ideas, experiences and attitudes. Responsibility refers to the principle that students have to take responsibility for using what they have learned. Unless the student takes explicit responsibility, a learning process may have no effect on the student's behavior in private or professional lives. This taking responsibility may also lead to new learning questions, which in turn lead to readiness for the next step in the learning process.

Awareness, (dis-)identification and contact. A second important characteristic of Confluent Education is that this method aims to contribute to personal growth and relationships by developing awareness (Brown et al., 1976). Awareness can be described as recognizing what is going on in oneself by reflecting on what is seen, heard, felt and thought in this moment. According to Confluent Education, awareness brings people in louch with human qualities like empathy, compassion, patience and non-judgement (the letting go of the 'shoulds and oughts'). In addition, awareness gives people the ability to be fully present in the 'here and now'.

A third characteristic of Confluent Education is its emphasis on identification and dis-identification of program instructors with students and vice versa. In this context, to identify means to go beyond ones own intrapersonal 'boundaries' and to associate with the other person. To dis-identify can be described as disassociating with the other afterwards, and returning to one's own boundaries. In educational programs, nurses have to experience that identification is necessary in order to be sensitive to the patients' needs, and that dis-identification is necessary to prevent projections and strong dependencies between persons.

What can happen when awareness and (dis-)identification are lacking, can be illustrated by the remark of a nine-year old girl who told us: "When my mother gets cold, she makes me put on a sweater". The mother projected her own feelings and needs on her daughter. There are often analogous situations in instructor-student and nurse-patient relationships. Instructors/nurses may assume that their own awareness is the same as the students'/patients', and they thus can decide what is best for the other persons. This phenomenon is illustrated by the following cases. 


\section{Chapter 4}

Question 1: W/Lat often tappens in human interactions?

Between mother-child:

The mother feels cold and she projects lier own coldness on the child. The nother presses the child to put on a sweater.

\section{Between instructor-participants:}

Thie instructor thinks that she is the appropriate person to decide what the participants should know and how they should learn is.

The program does not really match the worlds of the participants, and is therefore poorly applied in practice.
Tlie projection of the nuther prevents buth mother and clild from developing their own awareness and hecoming autononous people.
The nother flocs not realize ber ow the same experiences.
Participants are not aware of the instructor's position of power, which results in adnission ("you're right"). This hinders the leaming process.
Berween nurse-patient:

The nutse thinks that the patient is in pain and says, without asking about the patient's needs: "I'll give you a painkiller".

The nurse does not realize that she is giving a personal interpretation of sumeone else's feelings. Neither does the nurse realize that it is important to ask the patient whether observations are correct. or what the patient's wishes are.

The patient is not aware of his suhordinate position and leaves the decision to the nurse as she is the 'expert'. This reinforces the dependence of the patient.

According to Confluent Education, persons (e.g. parents, instructors or nurses) have to be aware of their own intrapersonal process. Out of this awareness real contact can occur ("I think or feel this. What about you?"), and out of this contact an intervention (e.g. putting on a sweater, choosing how to learn or giving painkillers) can be chosen. Awareness may lead to taking responsibility for oneself, and to giving the other person the opportunity to become aware and responsible. This leaves responsibilities where they belong, without taking them over from, or forcing them on others. This approach is demonstrated in the next cases. 
Question 2: How can things go differently?

In muther-child relationships:

The mother realizes that she herself would like 10 put on something wam and confortable and takes care of herself. She is aware of her own coldness. This awareness causes her to tell her daughter: "I an cold", and to ask: "What about you?" and "Would you like to put on a sweater?".

Total symbiosis berween mother and daughter is avoided. The child is enabled to be aware of her own feelings and to decide what she needs.
In ecucational programs:

The instructor realizes that the learning process of each participant is unique. The instructor also realizes that her relation with the participants determines the learning results. This awareness causes the instructor to tell the participants: "I would like to be responsive to your learning needs. Therefore, I will indicate what will be taught, but I invite you to decide with me how you want to learn this".

On the basis of the participants' answers and questions, the instructor decides what should be done so that participants gain clear insight into the themes discussed. In addition, responsibility for the entire learning process is shared between instructor and participants.
In wursing practice:

The nurse realizes what happens to him/her in contact with the patient. This awareness causes the nurse 10 ask the patient: "How ure you feeling? Are you in pain?". And if so: "How would you describe your pain?", and "What would you like me to do for you at this moment?".

On the basis of the patient's reactions, the nurse chooses nursing interventions. The patient is actively involved in decision making. and becomes more aware of personal feelings and needs.

It is important in educational processes, as well as in other interpersonal processes, to make a clear distinction between 'mine' and 'yours', to recognize one's own feelings and attitudes and not project them on the other. Through this awareness real contact becomes possible: a genuine response is made to the other's question, and the 'I-Thou' relationship, in Buber's (1970) sense, starts to work.

\section{Confluent Education in practice}

In the foregoing Confluent Education is described in rather abstract terms. In the following, a more literal picture will be painted, by sharing experiences with Confluent Education in the pain CE program. Within this framework, the first session of the program will be discussed. The themes of this session were: 'What is pain', 'Nursing pain interventions' and 'Promotion of patients' autonomy' (see Appendix I).

Readiness (circle 1, see Figure 4.1). Readiness was achieved with a group conversation to get acquainted. Program instructors and participants got to know each other by telling about their private backgrounds (e.g. name, age and marital status) and their professional 


\section{Chapter 4}

lives (e.g. work experiences). Readiness was also created by an individual written assignment based on questions like:

"Why did you choose this course?"

"What do you want to do/learn in this course?"

"What don't you want to do/learn on any account?"

With this assignment and the group stock-taking afterwards, wishes and expectations becarne more explicit. In addition, the participants could observe each other's reactions and became aware of similarities and differences. These actions created the beginning of a safe, open atmosphere and joint responsibility for the success of the CE program.

Based on the participants' reactions, the instructors could make a definitive decision about the themes of this session. In addition, they could make a choice to start either in the cognitive or affective learning domain. In most cases, it was decided to start learning in a cognitive way. One reason for this decision was that some participants shared their fear that too much emphasis would be placed in the program on experiential techniques like role playing.

Cognitive domain (circle 2). The theme 'What is pain' was discussed in a group conversation. Questions related to this theme that were dealt with were "How can you knuw that a patient is in pain?". "When do you call it pain?", "How do you regard pain as a nurse" and "How do you think you should act when a patient is in pain?". After some discussion, one of the instructors presented a brief introduction on the following definition: "Pain is whatever the experiencing person says it is, existing whenever he says it does" (McCaffery, 1972). It was argued that based on this definition the patient is the main pain expert and the main source of information about pain.

Affective domain (circle 3). After that, the participants were asked to split up into small groups. With reference to the foregoing, they received the following questions and assignment:

Think of one of the patients you are nursing now. Imagine that you want to check if this patient is in pain and, if so, you want to check the symptoms of this pain. Discuss what to do and what questions you should ask to find out. In doing so, think in terms of McCaffery's definition of pain (see before).

What change in your attitude do you notice when relying on this definition? What is gained by you and the patient as a result of this change in attitude?

What problems do you anticipate when relying on this definition?

During the discussion in small groups and the plenary discussion afterwards, the participants were given the opportunity to discuss their personal experiences, opinions and problems. Relying on McCaffery's definition of pain, the participants could create an awareness of what was going on in themselves in caring for patients in pain. This was necessary to fully understand that pain is a subjective feeling, that pain is what the patient says it is. and that pain is as severe as the patient says it is.

Responsibility (circle 4). After attention had also been paid to the other two themes of the session (see Appendix 1), at both cognitive and affective level, a group evaluation was initiated by the following question: "Could you please look back for a moment and clarify 


\section{Confluent Education}

for yourself what you have become aware of in this session, and what you have learned?". Learning can be enhanced greatly when the participant perceives the subject matter to be relevant (Keltner, 1983; Wake, 1987), and a connection is made with everyday life and work. This was done by means of the following questions: "Do you think that you will apply what you have now learned or discovered in your professional or private life?. If yes, how? And if no, why not?". In this way, the participants could take responsibility for applying (or not applying) what they had learned. Some participants also became more aware of questions concerning the subject matter. This illustrates how creating responsibility may also lead to new readiness to learn. Two illustrative remarks by participants:

"The moment you asked us what we would like to learn, I noticed that I thought and felt that you were the one to decide that. Later on I discovered that I thought I should know everything about pain. This thought, that I ought to know everything, often makes me feel powerless. Am I the only one who thinks like this? And would it be possible to pay attention in the next session to the subject of feeling powerless? I find this important because this feeling sometimes comes over me with patients who are in pain".

"Relying on the definition that pain is what the patient says it is, helped me to see the difference between what I think and what a patient thinks about pain. I also noticed that it is difficult for me to take an inquiring position in relation to the patient. It is difficult for me to believe what the patient is telling me about pain, especially if it does not correspond with my opinion. How am I to deal with this problem?".

By 'sharing', the participants were able to put their own unique experiences, opinions and feelings into words. They could also identify with other participants' experiences and discover differences and similarities. In addition, they could also experience that there was no need for them to live up to the instructors' expectations. In this way, a 'total symbiosis' of instructors and participants was avoided and the latter could take responsibility for their own learning process.

For instructors, it is also important to hear negative feedback, as this helps to clarify participants' wishes and learning needs. In addition, when instructors listen to negative comments nondefensively, they can set an example of how participants in their turn can deal with patients having negative experiences. This is useful, especially in cases of patients with pain. Pain often evokes negative thoughts and reactions, e.g. "If you could only feel what I'm going through". Nurses who have experienced that they are free to have negative thoughts and feelings may be better able to identify with patients in pain, who sometimes also view themselves and their surroundings in a negative light.

Approach in subsequent sessions. The same approach, in principle, applied to the subsequent sessions. Readiness was brought about at the beginning of a session. First, by paying attention to what was going on in the 'here and now', second by sharing (home work) experiences of the last week, and last by asking what and how participants wanted to learn in the current session. In all sessions, the instructors then made a careful choice, based on the participants' reactions, of whether to start learning in a cognitive or a more 
affective mode. As mentioned above, most sessions began in the cognitive mode. A lecture given by the instructors or a group discussion then served to introduce a particular theme. By working in the cognitive domain, the instructors created readiness for moving on to the affective domain. However, when participants did not have a preference for cognitive learning, the instructors started in the affective domain, for example with questions such as "Have any of you experience with this theme?" and "Are you willing to share what your experiences are on this theme?". An important advantage of starting in the affective domain is that this creates more 'hunger for knowledge', and a meal is more enjoyable when one is hungry. At the end of each session, the aspect of taking responsibility for practising what was learned received attention. The common approach was in principle the same as described before. By looking back upon that particular session, and also by taking stock of what the participants intended to use, these evaluation moments were used to make a bridge between theory and practice, and between the program and hospital.

\section{Closing remarks}

Nursing in general, and nursing pain assessment and management in particular, depend to a large extent on the knowledge the nurse has acquired. Yet, in a profession which aims to offer integrated cure and care, it must not be forgotten that nurses' interventions are also influenced by more affective ways of knowing. Confluent Education, an educational method in which the cognitive and affective learning domains flow together like two streams merging into one river, seems therefore to be ideally suited for pain CE programs. We assume that the use of such an integrated method will lead to a greater chance that the material learned will be applied in practice. Unfortunately this assumption can not yet be strengthened with empirical data from nursing $\mathrm{CE}$ research. It is therefore worthwhile to compare the influence of Confluent Education strategies to more cognitiveoriented approaches in future studies on pain CE programs.

Finally, a remark for program instructors. In our opinion, it is very important for instructors to realize that the learning process may be greatly affected by the quality of the instructor-participant relationship (Peterson \& Walberg, 1979). The participants' attitudes, skills and know-how will be built-up through interactions with instructors. As Brown (1981) states:

"If the teacher has excitement, enthusiasm, commitment and involvement in his teaching because he is directly connected to his teaching at each moment, there will be a corresponding impact on the student. He can identify with the teacher because he is there to identify with. There are ways to learn to be present, to be more totally involved. There are ways to learn to make contact and to be available for contact for others". 


\section{Confluent Education}

\section{References}

Alexander MA (1990). Evaluation of a training program in breast cancer nursing. Journal of Continuing Education in Nursing 21, 6, 260-266.

Boekaerts M (1987). Psychulogie van de leerling en het leerproces. Nijnegen: Dekker \& Van de Vegt Brown GI, Yomans T \& Grizzard L (Eds., 1975). The live classroom. New York: The Viking Press.

Brown GI. Phillips M \& Shapiro S (1976). Getting it all together; Confluent Education. Bloomington, Indiana: The Phi Delta Kappa Educational Foundation.

Brown GI (1981). Systems, process and assorted constnucts. Santa Barbara: University of California.

Brown GI (1990). Human teaching for human leaming: an intraduction on Confluent Education. New York: The Gestalt Joumal Company.

Buber M (1970). I-Thou. New York: Charles Scribners.

Castillo GA (1974). Lefi handed teaching. New York: Praeger.

Gerards FM (1987). Interpersoonlijke kommunikatie. In V Damoiseaux, FM Gerards, GK Kok \& F Nijhuis (1987). Gezondheidswoorlichting en -opwoeding. Assew/Maastricht: Van Gorcum.

Keltner NL (1983). The perceived impact of continuing education on the practice of nurses working in acute care facilities. Western Joumal of Nursing Research, 5, 21-40.

Maslow AH (1968). Toward a psychology of being. New York: Van Nostrand Reinhold company.

McCaffery M (1972). Nursing management of the patient with pain. Philadelphia: J.C. Lippincott Company.

Nattiv A (1986). The effects of cooperative learning strategies on academic achievement among sixth grade social studies students. Unpublished PhD-thesis. Santa Barbara: University of Califomia.

Perls FS (1970). Gestalt therapy verbatim. New York: Highland.

Peterson PL \& Walberg H (Eds., 1979). Revearch on teaching. Berkeley, Califomia: McCutcheon.

Ross Paulk J (1985). Comparison of the effects of confuent verses traditional contraceptive education on young people's knowledge, attitudes and behaviors. Unpublished PhD-thesis. Santa Barbara: University of California.

Wake M (1987). Effective instruction in continuing nursing education. Joumal of Continuing Education in Nursing $18,6,188-192$ 
CHAPTER 5 Pilot study on the effects of the program

This chapter is an adapted version of the article 'Pain assessment and management in surgical cancer patients: pilot and evaluation of a continuing education program'.

Published in 1995 in the Journal of Continuing Education in Nursing 26. 5, 214-218. Authors: AL Francke, H Huijer Abu-Saad \& M Grypdonck. 


\section{Pilot study on the effects of the program}

\section{Summary}

This chapter presents a pilot study that evaluates the impact of a CE program on pain assessment and management. Questionnaires were completed by nurse participants at the beginning, the end, and two months after the end of the pilot program. After the pilot program, participants reported having engaged in qualitatively improved pain interventions.

This chapter also discusses the usefulness of pilot studies in general. This type of study may steer decisions whether or not to continue the implementation and evaluation of programs. In addition, pilot studies provide useful information about the extent to which programs or measurement instruments need adaptation.

\section{Introduction}

Like medical and psychotherapeutic trials (Schwartz et al., 1980), CE studies may pass through several phases. In phase $I$, the plan for a program is tested in a small number of participants. If necessary, the program plan is adjusted on the basis of these experiences. In phase $I I$, an indication of the effectiveness of the program is obtained, using a small group of participants, usually without a control group. Findings from this phase are used in making the decision whether or not to proceed to the following phase. In phase III, the program's effectiveness is investigated in a larger group of participants, using a design with a control group. After this phase, the decision is made whether or not to implement the program outside the research setting.

Phase III intervention studies are best known, whereas phase I/phase II studies are rarely reported in nursing research literature. Therefore, this chapter describes rather thoroughly a phase 1/phase II study (to be further indicated as 'the pilot study') in which a $\mathrm{CE}$ program on pain assessment and management was implemented and evaluated. The main aim of the pilot study was to obtain indications of the program's effectiveness before initiating a larger, controlled intervention study.

\section{Pilot program}

Pilot program characteristics ${ }^{\prime 4}$. As described in Chapter 3, the program plan was developed on the basis of a needs assessment study. The general objective of the program was to improve nursing pain assessment and management practices by increasing nurses' knowledge and skills and by affecting attitudes.

The thirteen nurses ${ }^{13}$ participating in the pilot program came from four Dutch general hospitals and one university hospital. Participants were active in surgical wards,

\footnotetext{
14. Ar important difference with the definitive program (described in Appendix I) was that the pilot program involved only one program instructor. Another difference concerns the duration and number of the program sessions (six four-hour sessions in the pilot versus eight three-hour sessions in the definitive program)

1". One of these nurses would also be involved in the controlled intervention stody described in the Chapters 6-9.
} 
admitting both patients with cancer surgery and general surgery. Indirect recruitment of participants was done by nursing directors. The program instructor had a professional background in nursing, psychotherapy and nursing education.

The pilot program consisted of six weekly four-hour sessions and was held in a room of one of the participating hospitals. Major program components were transfer of knowledge and skills and the mutual exchange of (learning) experiences concerning: characteristics of pain, assessment of pain, psychosocial interventions, physical and relaxation interventions, and pharmacological pain management.

The educational method used was Confluent Education (see Chapter 4; Brown, 1990; Francke \& Erkens, 1994).

\section{Evaluation of the pilot program}

\section{Research aim and questions.}

The exploratory research questions for the pilot study were:

1. Does the pilot program affect number, duration and quality ${ }^{16}$ of surgical cancer nurses' psychosocial interventions in patients with pain?

2. Does the pilot program affect other nursing outcome variables related to pain assessment or management? More specifically formulated, does the pilot program affect surgical cancer nurses'

- knowledge and attitudes regarding pain management?

- pain assessment practices?

- $\quad$ physical and relaxation interventions? ${ }^{17}$

For the first question it was expected that participants would report more frequent psychosocial interventions after the program, but that changes in scores would be fairly small. The number of psychosocial nursing interventions are in general high (Pool, 1983; Maes, 1988), and a CE program could probably have only a minor effect on this outcome variable. Larger positive effects were expected in duration and quality of psychosocial interventions. It may be assumed from earlier research (e.g. Armstrong-Esther et al., 1994; Maes, 1988) that nursing psychosocial interventions (e.g. in the form of conversations at a patient's bedside) are usually rather short. For this reason, increased duration would be interpreted as a positive effect.

For the second research question, participants were expected to show positive changes in knowledge and attitudes regarding pain management. It was also expected that participants would report both quantitative and qualitative improvements of pain assessments, and physical and relaxation interventions.

${ }^{15}$ In this context, with 'quality' is meant 'the way in which interventions are executed. '

". With 'physical and relaxation interventions' is meant the use of massage, relaxation, distraction, physical and environmental comfon measures, cold and heat. 
Methods. Due to the explorative nature of the pilot study a pretest-posttest design without control group was used. There were three measurement points ${ }^{18}$ :

at the start of the pilot program (TI):

at the end of the pilot program (T2);

two months after the pilot program (T3).

Effects of the program at T2 were measured in ten of the thirteen participants. Two participants were ineligible for evaluation because they did not finish the program (due to personal reasons). One participant was ineligible because she did not meet the inclusion criterium 'being a qualified nurse'. Effects were measured at T3 in nine participants; one of the participants did not send in the questionnaires in that period.

In the framework of research question 1, participants were requested to react on the first version ${ }^{19}$ of the Adapted Therapeutic Behavior Scale (Francke, 1991), which is an adaptation of the Therapeutic Behavior Scale (Therapeutisch Gedragsschaal) constructed and examined for validity and reliability by Pool (1983). The first adapted version consisted of thirty items and measured number, duration, and quality of the provision of information, emotional support and promotion of autonomy. These interventions can reduce anxiety and stress, and can indirectly have a pain-reducing effect (Pool, 1983; Shade, 1992).

On Pool's original scale respondents had to rate how often they performed a particular intervention by reacting with 'very often', 'often', 'sometimes', 'rarely' or 'never'. However, positive effects may not always be manifested in the scores since a response shift may occur as a consequence of participating in a program (Sprangers, 1988). To reduce this type of interference, the first version of the Adapted Therapeutic Behavior Scale asked for the precise number of interventions. Another difference with the original scale was that the adapted version also asked for duration and quality.

For research question 2, participants were asked to fill in a conceptual self-report questionnaire developed for the purpose of this pilot study. The fifteen questions of the conceptual questionnaire were based on relevant pain literature (e.g. McCaffery \& Beebe, 1989) and concerned nurses' knowledge and attitudes concerning pain management, pain assessments, and physical and relaxation interventions ${ }^{20}$.

Considering the small sample and the exploratory character of this pilot study. only descriptive statistics have been used for analysing the data.

\footnotetext{
17. The posttests in the pilot study took place sooner after the program than those in the controlled intervention study (presented in the Chapters 6-9). This is related to the fact that due to time limitations the pilot had to be concluded in a shorter time span than the controlled intervention study.

19. The first version was again adapted after the pilot study, which resulted in the definitive Adapted Therapeutic Behavior Scale described in Chapter 7.

${ }^{20}$. After the pilot study, items of the conceptual self-report questionnaire would be integrated in one of the following questionnaires used in the large-scale intervention study: the Pain Assessment Questionnaire (see Chapter 6), the Questionnaire on Attitudes towards Psychosocial, Physical and Relaxation Interventions (see Chapter 7), the Physical and Relaxation Interventions Questionnaire (see Chapter 7) and the Questionnaire on Knowledge of Analgesics (see Chapter 8).
} 


\section{Chapter 5}

\section{Effects of the pilot program}

Participants' scores on the conceptual self-report questionnaire suggested that the program led to positive changes in knowledge and attitudes regarding pain management, pain assessment practices, and physical and relaxation interventions (see research question 2). However, since the conceptual self-report questionnaire was in a very preliminary state, it does not seem useful to discuss these scores in great detail. For this reason, attention will further be focused on the effects of the pilot program on psychosocial interventions (see research question 1), measured by the first version of the Adapted Therapeutic Behavior Scale.

Analysis revealed that the majority of respondents in $T 2$ and $T 3$ showed an increase in reported number of psychosocial interventions (see Table 5.1). As expected, these changes in number were rather moderate: in $T 2$ as well as in $T 3$, the average increase in number was less than 0.2 on a scale of 1 to 5 . Thus the expectation that as the number of psychosocial interventions would increase only a little, was supported.

Table 5.1: Number of respondents which did (or did not) report positive effects of the pilot program on dimensions of psychosocial interventions.

\begin{tabular}{|ll|ll|}
\hline $\begin{array}{l}\text { Poshosocial } \\
\text { interventions }\end{array}$ & Erfects & $\mathrm{T} 2$ & $\mathrm{T3}$ \\
\hline Number & yes & 7 & 6 \\
& no & 3 & 3 \\
Duration & yes & 10 & 9 \\
& nos & 0 & 0 \\
Quidity & yes & - & 9 \\
& no & - & 0 \\
\hline
\end{tabular}

A measure of change in duration of psychosocial interventions was constructed as follows: the number of items (of a total of thirty items) on which a respondent reported spending less time was subtracted from the number of items on which a respondent reported spending more time. In period $\mathrm{T} 2$, as well as in period $\mathrm{T} 3$, the average score was +12 . On the basis of the individual scores it appeared that all ten respondents (see Table 5.1) reported spending more time on psychosocial interventions after the pilot program. This supported the expectation of beneficial effects on reported duration.

The expectation that the reported quality of psychosocial interventions would increase was also supported. Changes which indicated a quality decrease were not reported $^{2 !}$. However, changes which indicaled a quality increase were reported by all

\footnotetext{
21. The researcher's evaluations, whether reponed changes indicated a quality increase or decrease, were conpared with an extemal researcher's independent assessnents. These evaluations agreed in $100 \%$ of the ciases.
} 


\section{Pilot study}

respondents in $\mathrm{T} 3^{23}$ (see Table 5.1): on average in 9 of the 30 items. "Being more patient oriented" was the most frequent written description of changes indicating an increase in quality. One of the respondents gave the following explanation of what she meant by a more patient oriented approach:

"That I now ask patients what they would like to know, what their questions are, and that I then try to tune into these questions the best I can. Often these questions concern something like: "I'm afraid it will be very painful, and what do I have to do then?".

\section{Closing remarks}

As described, nurse participants reported positive effects, particularly on the duration and quality of their psychosocial interventions. Based on these results, it seemed justified to continue the project with a controlled intervention study involving a larger group of nurses and also patients.

In addition, the pilot study provided information about the extent to which questionnaires were practicable and comprehensible. Respondents had little difficulty with questions and answer categories of the first version of the Adapted Therapeutic Behavior Scale; only small adaptations of the questionnaire seemed necessary ${ }^{23}$. The conceptual self-report questionnaire concerning nurses' knowledge and attitudes, pain assessments, and nonpharmacological interventions, was also comprehensible to the participants, but seemed to be too incomplete to get a valid picture ${ }^{24}$. For this reason, many other items were integrated in the definitive questionnaires used in the controlled intervention study. e.g. items based on the recent questionnaires of Dalton (1989) and McCaffery et al. (1990).

Moreover, experiences with the pilot program gave insight into the extent to which the program plan needed adjustments. The program instructor expressed that she had a rather hard and lonely job. Especially when working in the affective learning domain, she experienced a need for closer professional cooperation and feedback. Based on these experiences, it was decided to involve two instructors in the definitive program (see Appendix 1). In addition, nurse participants advised a change in the time structure of the program. They thought a four-hour session too long to maintain attention. However, they considered six sessions too few; they were eager to learn more about the subject of pain

n. Information regarding quality of psychosocial interventions was only requested in period T3; respondents' reactions in $\mathrm{T} 2$ had irdicated a need to assess not only number and duration, but also quality of interventions.

23. Respondents of the pilot study indicated that it was sometimes difficult to remember precise numbers of interventions. Therefore, in the definitive Adjusted Therapeotic Behavior Scale (described in Chapter 7 ) participants were asked whether an intervention was practised 'I or more times a day.' ' $1-4$ times a week,' ' $1-3$ times during the entire past month', or 'none at all.' Another difference between the first and the definitive version is the number of items ( 30 versus 35 ).

34. More attention is paid to general characteristics and disadvantages of self-report questionnaires in Chapter 7 and in the General Discussion. 


\section{Chapter 5}

assessment and management. It was decided therefore that the definitive program would consist of eight sessions, lasting three hours each. Participants also advised to implement the definitive program in nursing teams working together on one ward. This would make it easier to share learning experiences with close colleagues and to apply new knowledge and skills in practice.

Although the pilot study has proved to be valuable, it has obvious limitations. Inherent in the nature of this type of studies, the pilot study has provided an indication, but no 'hard' evidence, of program effectiveness. The controlled follow-up study (Chapters 6-9) had to show whether the program indeed had a positive impact on nursing practice. Nevertheless, it should be clear how useful pilot studies are. For instance, justification of a large intervention study could be provided (e.g. to nursing directors, physicians or project funders), by presenting the results of the pilot study. Furthermore, questionnaires and program plan could be perfected on the basis of the pilot study. Conducting such a small-scale study first, may reduce the chance of a large -and consequently expensive and labor intensive- study being prematurely halted or revealing nothing.

\section{References}

Annstrong-Esther CA, Browne KD \& MCAfee JG (1994). Elderly patients: still clean and sitting quiedy. Journal of Advanced Nursing 19, 264-271.

Brown GI (1990). Human teaching for human learning: an introduction to Confluent Education. New York: The Gestalt Journal Company.

Dalton JA (1989). Nurses' perceptions of their pain assessment skills, pain management practices, and attitudes toward pain. Oncology Nursing Forum 16, 2, 225-231,

Francke AL (1991). Verpleegkandigen, chirurgische kankerparienten en pijn. Unpublished report. Rotterdam: Helen Dowling Institute.

Francke AL \& Erkens MJM (1994). Confluent Education: an integrative approach for (nursing continuing) education. Joumal of Advanced Nursing 19, 354-361.

Maes H (1988). De communicatie tussen patiênt en student-verpleegkundige: Een exploratief onderzoek. Unpublished doctoral dissertation. Louvain: Catholic University.

MeCaffery M (1979). Nursing management of the patient with pain. Philadelphia: J.C. Lippincott.

McCaffery M \& Beebe A (1989). Pain. Clinical Manual for Nursing Pracrice. St. Louis-BattimorePhiladelphia-Toronto: the C.V. Moshy Company.

McCaffery M. Ferrell BR, O'Neil Page E, Lester M \& Ferrell B (1990). Nurses' knowledge of opiate analgesics and addiction. Concer Nursing 13,1, 21-27.

Pool JJ (1983). Sociaal-therapeutisch gedrag wan verpleegkundigen. PhD-thesis. Amsterdam: Free University.

Schwartz D. Flamant R \& Lellouch J (1980). Clinical trials. London: Academic Press.

Shade P (1992). Patient-controlled analgesia: can client education improve outcomes? Journal of Advanced Nursing 17, 408-413.

Sprangers M (1988). Response shift and the retrospective pretest. On the usefulness of retrospective pretestposttest designs in detecting training related response shift. $\mathrm{PhD}$-thesis. The Hague, The Netherlands: Institute for Education Research SVO. 
CHAPTER 6 Effects of the program on nurses' pain assessments

This chapter is an adapted version of an article submitted for publication.

Authors: AL Francke, JB Luiken, AME de Schepper, H Huijer Abu-Saad \& M Grypdonck. 


\section{Effects of the program on nurses' pain assessments}

\section{Summary}

Surgical nurses from five Dutch general hospitals participated in a CE program on pain assessment and management. Effects of the program were measured in a pretest-posttest controlled intervention study, in which nursing wards were randomly allocated to the experimental condition (program) or to the control condition (no program). This chapter deals with the effects on nurses' pain assessment practices. Statistical analyses revealed that the program led to an increase in the quality of nurses' activities relevant to taking pain histories. This increase in quality was still observable six months after the program, indicating some consolidation in nursing practice. However, no effects on the number of activities relevant to taking pain histories, and on the percentage of nurses who directly question patients about the presence of pain were established.

\section{Introduction}

Because of their intensive contact with patients, nurses are often considered the most obvious persons to gather information about pain (De Wit \& Van Dam, 1991; McCaffery \& Ferrell, 1994). Though nurses themselves also consider the assessment of pain as an important nursing task (see Chapter 3 and Francke, 1992), several lacunas in nurses' pain assessment practices have been described (Donovan et al., 1987a and 1987b; Juhl et al., 1993; Lieb Zalon, 1993; McCaffery \& Ferrell, 1994; Paice et al., 1991). For instance, Paice et al.'s study (1991) showed that only $60 \%$ of the surgical cancer patients interviewed could recall they were asked about their postoperative pain status by a nurse. Donovan et al. (1987a and 1987b) and Juhl et al. (1993) came to comparable conclusions. Furthermore, nurses do not make frequent use of pain measurement instruments, such as pain rating scales, and nurses seldom take a complete pain history (Dalton, 1989; Faries et al, 1991). As a result, pain is either overestimated or -more frequentlyunderestimated, inhibiting adequate pain relief (Grossmann et al., 1991; Lieb Zalon, 1993: Stephenson, 1994).

Continuing education is often recommended as an answer to the aforementioned problems (e.g. Dalton, 1989; Sullivan, 1994; Von Gunten \& Von Roenn, 1994). However, of the limited number of studies on the impact of pain CE programs (see Chapter 2), only three studies have investigated the effects of pain programs on nurses' pain assessment practices (Dols et al., 1995; McCardle \& Van der Wiel, 1993; McNaull et al., 1992). However, questions can be raised regarding the significance of the results due to the absence of pretest measurements in these studies. The lack of sufficient empirical data, prompted the setting up of an intervention study. The aim of this study was to provide insight into the effects of a pain CE program for surgical cancer nurses. The following research questions will be addressed in this chapter. 
Does the CE program result in:

1. an increase in the percentage of nurses who make use of direct questioning of patients as a method to determine the presence of pain?

2. an improvement of activities relevant to taking pain histories? More specifically formulated, does the CE program result in:

a. increases in number and quality ${ }^{23}$ of pain intensity assessments using rating scales?

b. increases in number and quality of other activities relevant to taking pain histories?

\section{Methods}

Design. Effects of the CE program were measured in a pretest-posttest control group design. Randomization took place at ward level ${ }^{26}$ : in each of the hospitals involved, nurses of one ward were randomly allocated to the experimental condition (program) and nurses of another ward to the control condition (no program). After the end of the research, nurses in the control condition as yet got the opportunity to participate in the CE program, as a reward for their cooperation in the study. Nurses in both conditions filled in a set of questionnaires at three measurement points:

- just before the program (T1),

- $\quad$ one month after the program (T2),

- $\quad$ and six months after the program (T3).

In addition, effect measurements took place among patients. Information on these measurements is provided in the Chapters 8 and 9.

Sample. A total of five Dutch general hospitals were involved in the study presented. These hospitals were chosen on the basis of geographical proximity. Entry in the hospitals was gained by contacting medical-ethical committees, nursing directors and physicians. In each hospital, two surgical wards, hospitalizing both cancer patients and noncancer patients, were involved.

All nurses who met the inclusion criteria 'having completed basic nursing education' and 'being involved in direct patient care activities' were asked to cooperate (coordinating head nurses and division managers who were not involved in direct patient care were not asked). However, six nurses of a total sample of $134(4.7 \%)$ did not participate. Reasons were: noncompliance $(n=2)$, practical impossibility $(n=2)$ and illnessipregnancy $(n=2)$. Of the 128 research subjects. 22 dropped out of the study. Reasons were: noncompliance $(n=3)$, illness/pregnancy $(n=4)$, resignation $(n=8)$,

2" In this context, with 'quality' is meant 'the way in which activities or interventions are executed.'

20. When wards are randomly allocated the chance of 'concamination of treatment' is lessened. However, even in the case of randomization of wards, nurses could exchange new knowledge and skills with nurses from another ward. Therefore, in the first session of the program, participants received an explanation of why it was important that they did not tell nurses from the control wards what they leaned in the program. After that. nurse participants had to promise secrecy during the research period. 
function change $(n=7)$. One of these 22 nurses also discontinued participation in the program. The effects of the program were determined on the basis of data from the 106 nurses who remained in the study until the last measurement point.

Program. The program was implemented in eight weekly sessions of three hours each. A follow-up meeting was held four months after the weekly sessions. Participation was team-based; nurses of one ward participated together. Two program instructors presented the program: one instructor had a nursing, psychotherapy and nursing education background, and the other an adult education background.

Confluent Education (see Chapter 4 and Brown, 1990) was the educational method used in the program. This student-directed method emphasizes the importance of integration of the 'learning of the head' and the 'learning of the heart'. This implies promotion of the development of knowledge and skills, as well as exchange of personal (learning) experiences and attitudes with respect to program items. Several educational strategies were used: verbal and audiovisual presentations, discussions (in the group as a whole and in subgroups), practical exercises and provision of literature (see Appendix 1). The main program items were:

a) pain and the assessment of pain (see below);

b) psychosocial interventions (psychosocial support, providing information and promoting autonomy);

c) physical and relaxation interventions (use of relaxation and distraction techniques, massage, cold and heat treatments and physical and environmental comfort measures);

d) pharmacological pain management (e.g. rationale of scheduled analgesics, effects and side-effects of opioids and nonopioids, and nursing tasks and responsibilities with respect to analgesics).

Approximately three contact hours were devoted to program item a), seven and a half to item b). six to item c), and four and a half to item d). The remaining contact hours were more general (e.g. group evaluations).

The themes were elaborated in keeping with the surgical-oncological background of the participants. This resulted in more emphasis on acute rather than on chronic pain assessment and management. Within the framework of 'Pain and the assessment of pain' (program item a), one of the instructors gave an introduction to the uniqueness and subjectivity of pain. She explained that "Pain is whatever the experiencing person says it is, existing whenever he says it does (McCaffery, 1972)". In a further group conversation the fact was discussed that because pain is subjective, the patient himself is the main source of information, and should -whenever possible- be asked about pain directly. In addition, nurses were taught how to take a pain history, and which activities are relevant in this regard (e.g. assessment of how the patient experiences his pain, and assessment of the intensity, location, quality and duration of pain, as well as aggravating and alleviating factors). Furthermore, nurses were taught how to use a numerical rating scale (Scott \& Huskisson, 1976) for assessing pain intensity. They were also taught how to display the pain intensity ratings in graphic-form in the patient files, in order to make changes in pain intensity visible to fellow nurses and doctors.

Content and educational method of the program are described in more detail in 


\section{Chapter 6}

Chapter 4 and Appendix 1 .

Instruments. The following item from Dalton's pain questionnaire (1989) was used to determine the number of nurses who directly questioned patients about pain:

- How do you find out that a patient is experiencing pain?

This open-ended question was translated into Dutch, and its validity and reliability established, by De Kuiper (1991). In the intervention study presented nurses' answers were coded using Dalton's structured coding scheme (administered by Dalton, available on request).

The 18-item Pain Assessment Questionnaire, a self-developed instrument, was used to measure the number and quality of activities relevant to pain history taking. The McGill Pain Questionnaire (MPQ, Melzack, 1975) translated into Dutch (Verkes et al., 1989) has been used as the main source of inspiration for the development of the Pain Assessment Questionnaire. Aspects of pain (e.g. intensity) about which the patient himself is asked in the MPQ have been translated in the Pain Assessment Questionnaire into nurses' activities (e.g. nurses' assessment of pain intensity). The first part of the Pain Assessment Questionnaire consists of one item on the number and quality of pain intensity assessments using rating scales:

To assess the intensity of a patient's pain by asking the patient to react on a pain rating scale (e.g. a numerical, visual or verbal scale)

A The average number of times I practised this activity in the past month is:

$0 \quad 1$ or more times a day

$0 \quad$ l-4 times a week

$0 \quad 1-3$ times during the entire past month

0 none at all

B Is the way you perform this activity different from the way you did when you first completed this questionnaire?

0 yes

0 no

0 not applicable

If yes, briefly describe the change

The second part of the Pain Assessment Questionnaire consists of seventeen items on other activities relevant to pain history taking. e.g. assessment of location, quality, duration, and aggravating and alleviating factors. All these items have the same structure and answer categories as the aforementioned item.

Eight pain experts established the content validity of the Pain Assessment Questionnaire. The questionnaire was tested in a group of fifteen nurses not participating in the study. The internal consistency of the second part of the questionnaire was high (Cronbach's Alpha $=0.93$ ). 
The individual scores on the Pain Assessment Questionnaire were calculated as follows. For the 'number category' (answer category A), on each dimension answers were transformed into the precise numbers ${ }^{27}$ of activities in the past month (the transformed numbers were $80 \times, 12 \times, 2 \times$ or $0 \times$ per month, respectively). These precise numbers were then added up and divided by the number of items in a dimension. For the 'quality category' (answer category B), respondents' open answers were first evaluated to determine whether there was an increase, a decrease or no change in quality. These evaluations were done separately by both the first author and an independent evaluator. When mutual evaluations did not correspond (in less than $5 \%$ of the answers), the scores on these items were treated in the statistical analyses as 'missing'. Then the number of items indicating a decrease in quality was subtracted from the number of items indicating an increase.

In addition, to gain insight into relevant background characteristics, written information was derived from nurses about their sex, function, educational level, participation in previous pain programs, age, and years qualified. Furthermore, data was gathered on aspects of work satisfaction and social desirability patterns using the Work Satisfaction Scale of Boumans (1990), and relevant items of the Dutch-languaged Marlowe Crowne Social Desirability Scale (Bruggemans \& Maes, 1986).

Data collection. The nurses from both conditions received a set of questionnaires two to three weeks before each of the three measurement points ( $T 1, T 2$ and $T 3$, respectively). Whenever nurses did not return the questionnaires within three weeks, they were approached by the researcher and again asked to submit them. Three nurses did not comply and for this reason dropped out from the study (see section 'Sample').

Statistical analyses. The Student t-test was used for continual data, and the $X^{2}$ test for categorical data to test differences in background characteristics between experimental and control groups, with a two sided significance level of 0.05 (see Table 6.1).

Effects of the program on 'Percentage of nurses who directly question patients about pain' and dimensions of 'Activities relevant to taking pain histories' were determined by MANCOVA for repeated measures, with statistical adjustment for 'Hospital'. To determine whether there was a significant difference in trend over time between experimental and control nurses, the interaction between condition and measurement point' was tested using the multivariate F-statistic. Testing was performed for each outcome variable separately. Because the program was expected to result only in positive effects, one-sided testing (with a significance level of 0.05 ) was applied.

\footnotetext{
77. Using a research design with three different measuremen moments, MANCOVA for repeated measures appeared to be the most appropriate procedure of analysis. Therefore, a transformation of the original ordinal data (with unequal distances between answer categories) into precise numbers was necessiry

The choice to transform ' 1 or more times a day' 10 ' $80 \times$ per month' was based on data from the pilot study (Chapter 5). The transformations to ' $12 \times, 2 \times$, and $0 \times$ per month' were based on the average values for the untransformed categories.
} 


\section{Chapter 6}

Table 6. I. Comparison between experimental and control nurnes in the 'remaining' and 'drop out' group. with respect to background characieristicr.

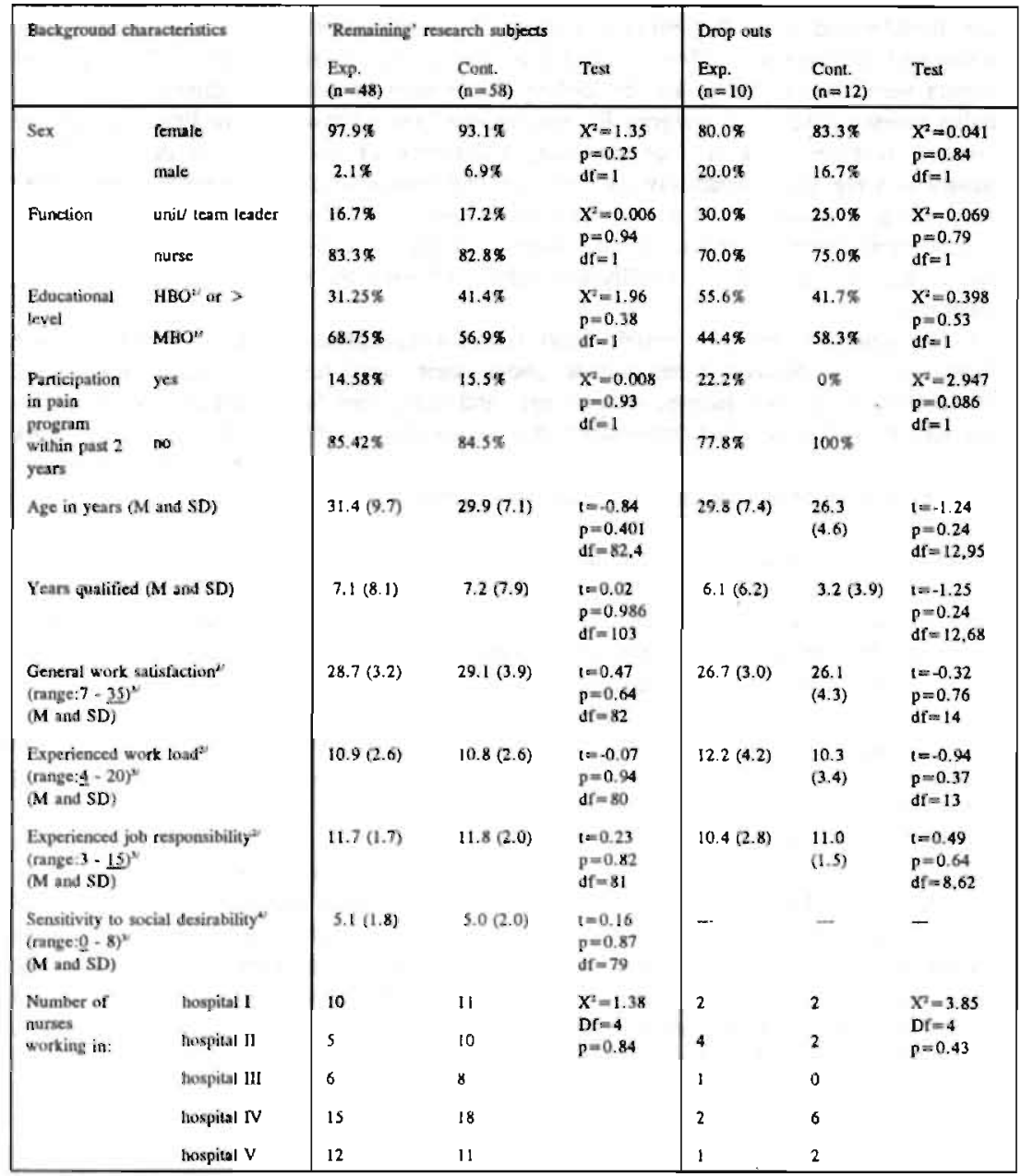

' $\mathrm{HBO}=$ Dutch highe $\mathrm{professional}$ aducation level.

MBO = Dutch secondary professional education level.

"Measured with Boumans:" work sarisfaction scale (Boumans, 1990).

"The most favorable scores are underlined.

* Determined snly for the group of nurses that parricipated until T3, and was measured with eight relevant items from the Dutch-languaged Marlowe Crowne Social Desirmbility Seale (Brugremans a Mass, 1986). 
Initially, data concerning 'Number of other activities relevant to taking pain histories' did not meet MANCOVA's assumption of normality (Stevens, 1986). Therefore, these data were square root transformed.

\section{Results}

Background characteristics. There were no significant differences between experimental and control groups with respect to relevant background characteristics (see Table 6.1). This applied to both the 'remaining' subjects who participated in the study until the last measurement point $(n=106)$ and the 'drop outs' $(n=22)$.

Percentage of nurses who directly question patients. The percentage of nurses who asked patients directly if they were in pain declined across the measurement points (see Table 6.2), both among experimental and control nurses. No significant differences between the two groups of nurses were found (see Table 6.2), and it can be concluded that the program had no effect in this respect.

Table: 6.2. Scores on 'Percentage of ruses who directly yuestion patients', 'Number and quality of pain intensily assessments by rating scales" and 'Number and quality of other activities relevant to taking pain histories', lested with MANCOVA for repealed measures'.

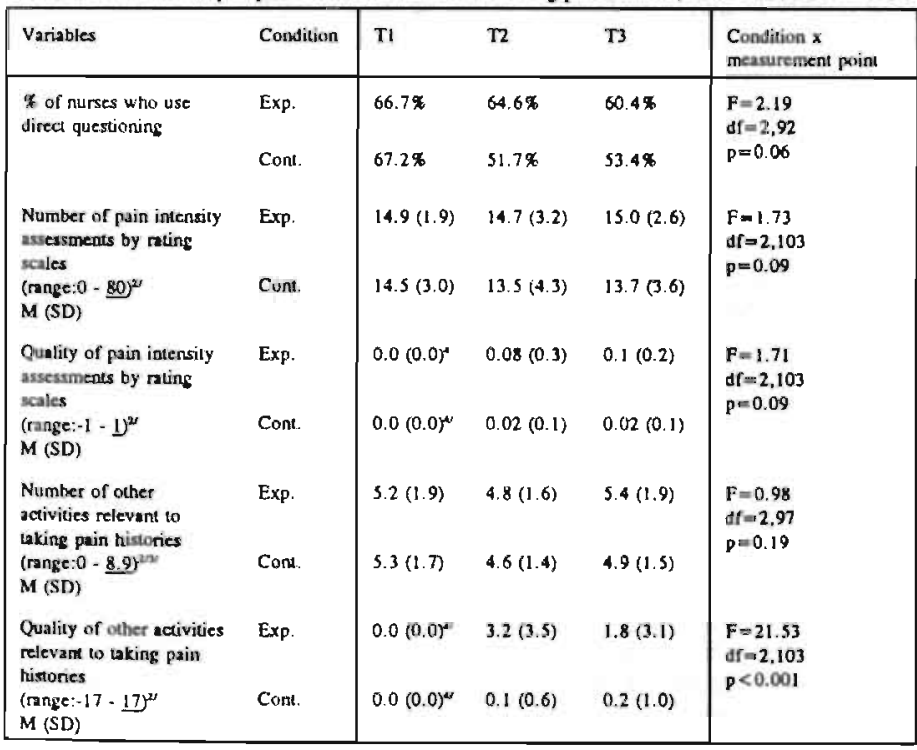

\footnotetext{
"With statistical adjustment for 'Hospilal'.

2) The mos favorable scores are underlined.

* Square rook transformed scores.

"In actualicy, there was no T1 measuremend for this dimension. As, however, a change in relation to $\mathrm{Tl}$ is required at $\mathrm{T} 2$ and $\mathrm{T3}$, a value of 0 was supplied for TI.
} 


\section{Activities relevant to taking pain histories}

Pain intensity assessments by rating scales. There were no increases in the number of pain intensity assessments using rating scales. Testing showed no significant difference in trend over time between experimental and control nurses (see Table 6.2). The experimental and control nurses also did not differ statistically with respect to changes in quality of pain intensity assessments using rating scales. Based on these findings it can be concluded that the CE program has not significantly affected the number and quality of nurses' pain intensity assessments using rating scales.

Other activities relevant to taking pain histories. Both among experimental and control nurses the number of other activities relevant to taking pain histories varies somewhat over time (see Table 6.2). These changes are not related to participation in the program, which can be inferred from the nonsignificant difference in trend between the two groups of nurses.

However, experimental nurses' quality of activities relevant to taking pain histories improved (see Table 6.2). This increase in quality was most apparent shortly after the program (T2), but is still observable in the longer term (T3). Control nurses showed no clear improvement, and there was a significant difference in trend between experimental and control nurses. These findings indicate that the $C E$ program resulted in an improvement of the quality of activities relevant to taking pain histories.

\section{Discussion}

First to reiterate the successful aspects, the CE program did result in an increase in the quality of activities relevant to taking pain histories. The fact that a half year after the program there was still an increase in quality, suggests some consolidation of what has been learned. In the Pain Assessment Questionnaire nurses described what these changes in quality concerned. They wrote, for example, "I now question patients about characteristics of their pain more extensively and thoroughly than before", "I go further into it", "I ask questions more directly and think it through more carefully", "I no longer fill in beyond what the patient says".

Although the quality of nurses" pain assessment practices did improve, quantitative aspects did not. The percentage of nurses who used direct questioning as a method to determine whether a patient is in pain had not increased. The number and quality of pain intensity assessments using pain scales, and the number of other activities relevant to pain history taking had also not increased. Several explanations may be given for these results. For instance, nurses who participated in the program indicated in qualitative evaluation interviews (see Chapter 10) that they were in general not very open to new approaches. Only when they considered an approach very important did they think it worth the adjustment of their daily routine activities. This may have particularly impeded a frequent and structural use of pain rating scales. Nurses' motivation to use such scales will increase when they are more aware of the importance of pain assessment for patients' health and well-being. It is therefore recommended for future pain CE programs that more emphasis be placed on the use of pain rating scales in relation to patients' comfort and function. For example, the importance of the use of pain scales becomes more apparent if nurses identify that patients indicating a less than 3 pain rating will be better 
able to ambulate and will feel more comfortable.

In addition, participants indicated that approaches such as taking pain histories and the use of rating scales were not translated into ward policy. This fact also inhibited the use of what they had learned in the CE program (see Chapter 10). In line with this finding, it seems relevant to investigate in future research whether a similar CE program combined with a formal implementation of a new pain assessment policy has a larger impact. A new pain assessment policy may be, for instance, the implementation of hospital-based protocols, including regular pain intensity or pain history assessments (for examples of such policies, see Davis, 1988; Hamers, 1995; McCardle \& Van der Wiel, 1993; De Wit \& Van Dam, 1991). Nurses who are in leadership positions bear the main responsibility for translating CE programs into ward policy. In this regard, it may be effective to let division managers or coordinating head nurses participate in future $\mathrm{CE}$ programs as well.

Furthermore, participants reported that physicians showed limited interest in the outcomes of nurses' pain assessments (Chapter 10). Therefore, nurses had the feeling that the impact of their pain assessment efforts on physicians' pain policy was limited. It seems important that within the framework of future CE programs clear arrangements are made between nurses and physicians on how data gathered by nurses are to be used in an interdisciplinary pain policy. This asks for close cooperation between nurses and physicians, for instance, within the framework of pain teams or services. Unfortunately, teams in which nurses work closely together on an equal base with other pain specialists are still quite uncommon in Dutch hospitals. Setting up such interdisciplinary teams may be an important step for the promotion of the use of pain CE programs in practice (Bookbinder et al., 1995; Max, 1990).

\section{References}

Bookbinder M. Kiss M, Coyle N, Brown MH, Gianella A \& Thaler HT (1995). Improving pain management practices. In DB McQuire, $\mathrm{CH}$ Yarbro \& BR Ferrell (Eds., 2nd edition). Cancer pain management (pp. 321-361). Boston: Jones \& Bartlet.

Bounans N (1990). Hes werk van verpleegkundigen in algemene zidenhuizen. Een onderzoek naar werkaspecten en hun invloed op verpleegkundigen. PhD-thesis. Maastricltt: University of Limburg.

Brown GI (1990). Human teaching for human leaming: an introduction to Confluent Education. New York: The Gestalt Joumal.

Bruggemans E \& Maes S (1986). Psychosociale effecten van een lange-termijn sportprogramma bij coronaire hartpatiēnten. De Psycholoog XXI, 497-498.

Dalton JA (1989). Nurses' perceptions of their pain assessment skills, pain management practices, and attindes toward pain. Oncology Nursing Forum 16, 2, 225-231.

Davis PS (1988). Changing nursing practice for more effective control of postoperative pain through a staff initiated educational programme. Nurse Education Todtry 8, 325-331.

Degner LF, Fujii SH \& Levitt M (1982). Implementing a program to control chronic pain of malignant disease for patients in an extended care facility. Cancer Nursing 5, 263-268.

Dols C, Forker J, Lumm M, Huff I, Johnson M, Morrell C. Prunty N, Riehl K, Sabey M \& Vail M (1995). Enhancing nurses' reliance on patients' perceptions of pain during pain assessiment: a comparison of two educational methods. Joumal of Continuing Education in Nursing 26, 5, 209213.

Donovan MI, Dillon P \& McGuire L (1987a). Incidence and characteristics of pain in a sample of hospitalized cancer patients. Cancer Nursing 10, 85-92. 


\section{Chapter 6}

Donovan MI, Dillon P \& McGuire L (1987b). Incidence and characteristics of pain in a sample of medicalsurgical inpatients. Pain, 30, 69-78.

Faries JE, Mills DS. Whitt Goldsmith K, Phillips KD \& Orr. J (1991). Systematic pain records and their inpact on pain control. Cancer Nursing 14, 6, 1991, 306-313.

Francke AL (1992). Wat doen verpleegkundigen bij pijn? Tijdschrift voor Ziekenverpleging, 13, 460-463.

Grossinan SA, Scheidler VR, Swedeen K, Mucenski J \& Piantadosi S (1991). Correlation of patient and caregiver ratings of cancer pain. Joumal of Pain and Symptom Management 6, 2, 53-57.

Gunten CF von \& Von Roenn JH (1994). Barriers to pain control: ethics and knowledge. Journal of Palliative Care, 10, 3, 52-54.

Hamers, JPH (1995). Postoperative pain in children. Assessment and intervention. $\mathrm{PhD}$-thesis. Maastricht: Datawyse.

Juhl IU. Christensen BV, Bülow HH, Wilbek H, Dreijer NC \& Egelund B (1993). Postoperative pain relief. from the patients' and the nurses' point of view. Acta Anaesthesiologica Scandinavioa 37, 404-409.

Kwiper M de (1991). Nurses' perceptions of their pain assessment skills, pain management practices and attitudes cowards pain. Unpublished master thesis. Wales: University of Wales.

Lieb Zalon M (1993). Nurses' assessment of postoperative patients' pain. Pain, 54, 329-334.

Max M (1990). American Pain Society quality assurance standards for relief of acute and cancer pain. In MR Bond, JE Charlton \& CJ Woolf (Eds.). Proceedings of the VI World Congress on Pain (pp. 185-189). Amsterdam: Elsevier.

McCaffery M (1972). Nursing the patient in pain. Philadelphia: JB Lippincott Company.

McCaffery M \& Ferrell BR (1994). Nurses' assessment of pain intensity and choice of analgesic dose. Contemporary Nurse 3, 3, 68-75.

McCardle $M$ \& Van der Wiel $Y$ (1993). Ervaringen van wijkverpleegkundigen met het afnemen van de pijnanamnese bij patiènten met kanker in de thuissituatie. Unpublished report. Nijmegen: Hogeschool Nijmegen en Integraal Kankercentrum Oost.

McNaull FW, McLees JP, Belyea MJ \& Clipp EC (1992). A comparison of educational methods to enhance nursing performance in pain assessment. Journal of Continuing Education in Nursing 23, 6, 267.

Melzack R (1975). The McGill Pain Questionnaire: major properties and scoring methods. Pain, 1, 277299.

Pake JA, Mahon SM \& Faut-Callahan M (1991). Factors associated with adequate pain control in hospitalized postsurgical patients diagnosed with cancer. Cancer Nursing 14, 6, 298-305.

Scott J \& Huskisson EC (1976). Graphic representation of pain. Pain, 2, 175-184.

Stevens J (1986). Applied multivariate statistics for the social scientists. Hillsdale, New Yersey, London; Lawrence Erlbaum Associates Publishers.

Stephenson NLN (1994). A comparison of nurse and patient perceptions of postsurgical pain. Journal of Intravenous Nursing 17, 5. 235-239.

Sullivan LM (1994). Factors influencing pain management; a nursing perspective. Journot of Post Anaesthesia Nursing 9, 2, 83-90.

Verkes RJ, Vanderiet K, Vertommen H, Van der Kloot WA \& Van der Meij J (1989). De MPQ-DLV: ten standaard nederlandstalige versie van de McGill Pain Questionnaire voor Belgiê en Nederland. In WA van der Kloot \& H Vertommen (red.). De MPQ-DLV. Een standaard nederlandstalige versic van de McGill Pain Questionnaire. Achtergronden en handleiding. Lisse: Swets en Zeitlinger. 5769.

Wit R de \& Van Dam FSAM (1991). Verpleegkundige pijnmeting bij kankerpatienten: een interventiestudie. Verpleegkunde. Nederlands-Vlaams Wetenschappelijk Tijdschrift voor Verpleegkundigen 5, 2, 68-75 
CHAPTER 7 Effects of the program on nurses' psychosocial, physical and relaxation interventions

This chapter is an adapted version of the article 'Effects of a pain programme on nurses' psychosocial, physical and relaxation interventions'.

Accepted for publication in the Journal of Patient Education and Counselling. Authors: AL Francke, JB Luiken, B Garssen, H Huijer Abu-Saad \& M Grypdonck. 


\section{Effects of the program on nurses' psychosocial, physical and relaxation interventions}

Summary

This chapter describes the effects of the pain assessment and management program on nurses' psychosocial, physical and relaxation interventions. It was established that participation in the program resulted in more positive attitudes towards physical and relaxation inserventions (such as attitudes towards relaxation, distraction and massage). In addition, the program led to an increase in the duration and quality of psychosocial interventions (duration and quality of information provision, emotional support, and promotion of autonomy). Furthermore, the program resulted in an increase in the quality of physical and relaxation interventions. However, the program did not lead to more positive attitudes towards psychosocial interventions, nor to increases in the numbers of psychosocial, physical and relaxation interventions.

\section{Introduction}

Meta-analytic studies have pointed to positive effects of nurses' providing of information and emotional support on patients' postoperative pain (Devine \& Cook, 1983 and 1986; Hathaway, 1986; Mumford et al., 1982). There is also empirical evidence that promoting patients' autonomy, for instance by actively involving patients in decisions about their treatment, may result in less distress for the patient, and, consequently, in a decrease of pain (Pool, 1983; Shade, 1992). On the basis of descriptive studies (Francke, 1992; Maes, 1988) it can be assumed that nurses do apply such psychosocial interventions rather frequently. However, the duration and quality of these interventions are, generally speaking, not optimal. For instance, discussions with patients are frequently brief and rather superficial (Armstrong-Esther et al., 1994; Maes, 1988). Distancing tactics are often used, and nurses' inadequate dealing with emotions form a barrier to effective and intense communication (Maguire, 1985; Northouse \& Northouse, 1987). In addition, there is often a gap between patients' needs, and the actual information and support patients receive from nurses or other care providers (Bensing, 1994; Schrameyer \& Brunenberg, 1992).

Research has also been done in the area of physical and relaxation interventions in patients in pain. Studies indicate that nurses helping patients to relax, e.g. through breathing or muscle relaxation exercises, has a favorable impact on postoperative pain (Hyman et al., 1989; Levin et al., 1989; Wells, 1982). Distraction (Cook, 1986; Locsin, 1981), physical and environmental comfort measures (Herr, 1992; VWR/CBO, 1994), massage (Fordham \& Dunn, 1994; McCaffery \& Beebe, 1989) and the use of cold and heat (Barbour et al., 1986; Fordham \& Dunn, 1994) would also relieve pain. Nevertheless, most of these physical and relaxation interventions are used only on a modest scale in nursing (Dalton, 1989; Francke, 1992; Halfens et al., 1994; Van der Linde, 1994; Schuurmans et al., 1993). Unfamiliarity with certain interventions or lack of acqaintance with their potential effectiveness, may provide an explanation for the limited use (see Chapter 3).

Several training programs on communication or psychosocial skills have been developed (e.g. Faulkner, 1992; Pool, 1983; Razavi et al., 1988). However, limited 
attention has been paid to psychosocial interventions within the framework of pain CE programs. In addition, only a few pain CE programs for nurses paid attention to physical and relaxation interventions (see Chapter 2). Because further research is needed in this field, an intervention study on the effects of a pain CE program directed to Dutch surgicial cancer nurses was carried out (see Chapters 6,8 and 9). This chapter aims to provide insight into the effects of the program on physical, psychosocial and relaxation interventions, and focuses on the following research questions.

Does the C.E program result in:

1. more positive attitudes towards psychosocial, physical and relaxation interventions?

2. increases in

a. the number of psychosocial interventions?

b. the duration of psychosocial interventions?

c. the quality ${ }^{28}$ of psychosocial interventions?

3. increases in

a. the number of physical and relaxation interventions?

b. the quality of physical and relaxation interventions ${ }^{29}$ ?

\section{Methods}

Design. As already described in Chapter 6, effects of the program on nurses were measured in a pretest-posttest control group design, with randomization at ward level. Nurses filled in a set of questionnaires at three measurement points: just before the program (T1), two months after (T2), and six months after the program (T3).

Sumple. In each of the five participating hospitals, two surgical wards were involved. The effects of the program were determined on the basis of data from the 106 nurses who remained in the study until the last measurement point. A detailed description of the sample is provided in Chapter 6 (section 'Sample' and Table 6.1).

Program. Major program items were: a) pain and the assessment of pain, b) psychosocial interventions, c) physical and relaxation interventions, and d) pharmacological pain management.

Within the framework of psychosocial interventions (program item b), attention was given to provision of information, emotional support and promotion of autonomy. For physical and relaxation interventions (program item $\mathrm{c}$ ), the use of massage, relaxation, distraction, cold, heat, and physical and environmental comfort measures were discussed. Usually, one of the instructors introduced a particular intervention subsequently discussed in the group as a whole or in small groups (see Appendix I). Central questions in the discussions were: "What are your ideas about these interventions?". What do you

2n. In this context, with 'quality' is meant 'the way in which interventions are executed.'

29. No questions were posed regarding the duration of physical and relaxation interventions, because there were no (emprical) indications on which to judge an increase of duration either positively or negatively. 
wish to know about them?", "Can you give examples of how, when and to whom these interventions apply?" and "In your opinion what is the effect of these interventions on pain?". Participants became more acquainted with the particular interventions through communication exercises, practising of foot massage, and breath and muscle relaxation exercises. Content, educational method and other characteristics of the program are described in more detail in Chapters 4 and 6 and in Appendix I.

Instruments. The Questionnaire on Attitudes towards Psychosocial and Physical and Relaxation Interventions is a fifteen item self-developed questionnaire used to assess nurses' attitudes towards psychosocial, physical and relaxation interventions. Attitudes in this context refers to the respondent's evaluative beliefs (negative-positive, pro-con; see Ajzen, 1988). All of the items include a scale from 0 to 10 , and a possibility for 'no opinion'. Below, one of the items (translated) is displayed.

Is teaching patients how to relax muscles a useful pain control method in your work?

Absolutely
not useful=0 $\quad \begin{array}{lll}2 & 2345678910 \quad \begin{array}{l}\text { Extremely } \\ \text { useful }=10\end{array}\end{array}$

$0=$ no opinion

This questionnaire was developed because there were no validated and reliable Dutch instruments for measuring attitudes towards psychosocial, physical and relaxation interventions available. However, some questionnaires had been developed in master thesis research (De Kuiper 1991; Derks, 1991). These latter questionnaires, in addition to relevant literature on pain (e.g. McCaffery \& Beebe, 1989), were a source of inspiration for the development of the new questionnaire. Eight pain experts evaluated the new questionnaire's content validity. The practicability and the comprehensibility of the questionnaire was tested on fifteen nurses who did not participate in other parts of the study. Using the data of the 106 research subjects in the intervention study, a principal component analysis for ordinal data was performed. It was established that the new questionnaire is two-dimensional. The first dimension (Cronbach's Alpha $=0.69$ ) concerns attitudes towards psychosocial interventions, while the second dimension (Cronbach's Alpha $=0.85$ ) measures the attitudes towards physical and relaxation interventions. Item scores were added up and, subsequently, divided by the total number of items of a particular dimension to calculate the total scores for each dimension.

The Adjusted Therapeutic Behavior Scale is a 35 item questionnaire used to determine effects on number, duration and quality of psychosocial interventions. The Adjusted Therapeutic Behavior Scale is an adaptation of the Therapeutic Behavior Scale (Therapeutisch Gedragsschaal, Pool, 1983). Every item of the Adjusted Therapeutic Behavior Scale includes the same 'number, duration and quality answer categories' (categories A, B and C, respectively). See, for example, the following item: 
To inform patients about what they can do to avoid (worse) pain.

A The average number of times I practised this intervention in the past month is:

01 or more times a day

$0 \quad 1-4$ times a week

$0 \quad 1-3$ times during the entire past month

0 none at all

B Each time I practice this intervention I spend:

0 less time than the first time I completed this questionnaire

0 the same amount of time as the first time I completed this questionnaire

0 more time than the first time I completed this questionnaire

C Is the way you practice this intervention different from the way you did when you completed the questionnaire the first time?

0 yes

0 no

0 not applicable

If yes, briefly describe the change ........................

In a pilot study an earlier version of the questionnaire was established as practicable and comprehensible (see Chapter 5 and Francke et al., 1995). The structure and internal consistency were determined using the scores on the 'number answer category' ${ }^{\text {'31 }}$ of the 106 research subjects in the intervention study under discussion. Principal component analysis for ordinal data indicated that the Adjusted Therapeutic Behavior Scale has two dimensions. The first dimension (Cronbach's Alpha $=0.91$ ) concerns general psychosocial interventions. With the term 'general' is meant not specifically focused on the pain problem of the patient. Dimension 2 (Cronbach's Alpha $=0.78$ ) is related to pain-focused psychosocial interventions. The scores for each dimension were calculated as follows. For the 'number answer category': the answers on each item were converted into precise number ${ }^{31}$ of interventions. Then the precise numbers were added up and divided by the number of items in that dimension. For the 'duration answer category': the number of items on which less time was spent on an intervention was subtracted from the number of items on which more time was spent on an intervention. For the 'quality answer category': respondents' open answers were first studied to evaluate whether there was an increase, a decrease or no change in quality. This was done for each item by both the first author and an independent evaluator. When their evaluations did not correspond

\footnotetext{
30. Because of its formulation, the 'number-answer category' was most suitable for determining the structure

". Set nort 24.
} 
(which was the case in less than $5 \%$ of the answers), the respondent's answer on that item was treated in the analysis as 'missing'. Subsequently, for each respondent the number of items indicating a decrease in quality was subtracted from the number of items indicating an increase.

The Physical and Relaxation Interventions Questionnaire is a twelve ttem questionnaire used to determine changes in physical and relaxation interventions. As in the item below, all items are succeeded by 'number and quality answer categories' (category $\mathrm{A}$ and $\mathrm{B}$, respectively):

To teach a patient how to relax by breathing in a particular way

A The average number of times I practised this intervention in the past month is:

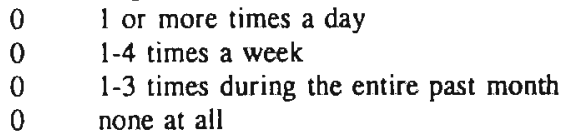

B Is the way you practice this intervention different from the way you did when you completed the questionnaire the first time?

$\begin{array}{ll}0 & \text { yes } \\ 0 & \text { no } \\ 0 & \text { not applicable }\end{array}$

If yes, briefly describe the change

The content validity, practicability and comprehensibility of the Physical and Relaxation Interventions Questionnaire was established in the same way as in the case of the Questionnaire on Attiudes towards Psychosocial and Physical and Relaxation Interventions (see before). The structure and internal consistency was determined utilizing data from the intervention study presented. A principal component analysis for ordinal data revealed that the questionnaire has a unidimensional structure (Cronbach's Alpha $=0.70$ ). The calculations and evaluations of the scores on the answer categories were performed in the same way as described with respect to the 'number and duration answer categories' of the Adjusted Therapeutic Behavior Scale. (For data collection procedures, see Chapter 6 ).

Statistical analyses. Effects of the program were determined by MANCOVA for repeated measures, with statistical adjustment for the variable 'Hospital'. Multivariate testing of the 'interaction between condition and measurement point' was done for each outcome variable separately (with a one-sided significance level of 0.05 ).

Data of some outcome variables (see below Tables 7.2 and 7.3) initially did not meet MANCOVA's assumption of normality and therefore on these data a square root transformation was applied. 


\section{Results}

Artitudes towards psychosocial and physical and relaxation interventions.

As shown in Table 7.1, attitudes of experimental nurses towards psychosocial interventions remained virtually unchanged over the three measurement points. This was the same for control nurses. Consequently, MANCOVA for repeated measures did not reveal any significant difference in trend between the two groups of nurses.

However, in the attitudes of experimental nurses towards physical and relaxation interventions a positive change over time occurred (Table 7.1). In the control condition, there was no such positive change, even a small negative change at $T 2$. Accordingly, there is a significant difference in trend between the experimental and control conditions. on the basis of which it can be concluded that the program had a positive effect on nurses' attitudes with regard to physical and relaxation interventions.

Table 7.1. Mean scores on atlitudes towards psychosocial and physical and relaxation interventions (SD's are between brackets). testod with MANCOVA for repeated measures".

\begin{tabular}{|ll|llll|}
\hline Attitudes & Condition & $\mathrm{T} 1$ & $\mathrm{~T} 2$ & $\mathrm{~T}$ & $\begin{array}{l}\text { Condition } x \\
\text { measurement poins }\end{array}$ \\
\hline $\begin{array}{l}\text { towards psychosocial } \\
\text { interventions } \\
\text { (range: } 0-10)^{2}\end{array}$ & Exp. & $7.7(1.7)$ & $7.6(1.4)$ & $7.6(1.3)$ & $\begin{array}{l}\mathrm{F}=1.06 \\
\mathrm{~d}=2.103 \\
\mathrm{p}=0.18\end{array}$ \\
$\begin{array}{l}\text { towards physical and } \\
\text { relaxation interventions } \\
\text { (range: } 0-10)^{2}\end{array}$ & Exp. & $5.6(1.5)$ & $0.3(1.5)$ & $6.2(1.5)$ & $\begin{array}{l}\mathrm{F}=7.34 \\
\mathrm{df}=2.101 \\
\mathrm{p}<.0 .001\end{array}$ \\
\hline
\end{tabular}

"With statistical adjustment for 'Hospital'.

2 The most favorable scores are underined.

\section{Psychosocial interventions}

Number. The number of general psychosocial interventions varied somewhat in time, both in the experimental and control conditions (see Table 7.2). The program did not seem to have any effect in this respect; there is no significant difference in trend between experimental and control nurses. The number of pain-focused psychosocial interventions varied during the research period in both groups as well, and there was no significant difference in trend between the two groups of nurses.

Duration. One month after the program and, to a lesser extent, six months after the program, experimental nurses indicated that they spend more time on general psychosocial interventions (see Table 7.2). Control nurses showed virtually no increase, and there was a significant difference in trend between the two groups of nurses. The conclusion is that the program resulted in an increase in the duration of general psychosocial interventions. 
Effects on nurses' psychosocial, physical and relaxation interventions

Table 7.2. Mean scores on dimensions of psychosocial interventions (SD's are belween brackets), tested with MANCOVA for repeated measures ${ }^{\prime \prime}$

\begin{tabular}{|c|c|c|c|c|c|c|}
\hline \multicolumn{2}{|c|}{ Psychosocial interventions } & \multirow{2}{*}{$\begin{array}{l}\text { Condition } \\
\text { Exp. }\end{array}$} & \multirow{2}{*}{$\begin{array}{l}\text { TI } \\
5.2(1.4)\end{array}$} & \multirow{2}{*}{$\begin{array}{l}T 2 \\
5.0(1.4)\end{array}$} & \multirow{2}{*}{$\frac{T 3}{5.3(1.3)}$} & \multirow{2}{*}{$\begin{array}{l}\begin{array}{l}\text { Condition } x \\
\text { measurement point }\end{array} \\
F=1.04 \\
d f=2.101 \\
p=0.18\end{array}$} \\
\hline Number & $\begin{array}{l}\text { general } \\
\text { (range:0 - } 8.9)^{25 y}\end{array}$ & & & & & \\
\hline & $\begin{array}{l}\text { pain-focused (nonge:0 - } \\
\underline{\text { 8.9) }})^{2 / 20}\end{array}$ & $\begin{array}{l}\text { Exp. } \\
\text { Cont. }\end{array}$ & $\begin{array}{l}5.5(2.0) \\
5.6(2.0)\end{array}$ & $\begin{array}{l}5.5(1.8) \\
5.3(1.7)\end{array}$ & $\begin{array}{l}5.3(1.7) \\
5.9(1.7)\end{array}$ & $\begin{array}{l}F=2.09 \\
d f=2.102 \\
p=0.06\end{array}$ \\
\hline Duration & $\begin{array}{l}\text { general } \\
\text { (range:-26-26) }\end{array}$ & $\begin{array}{l}\text { Exp. } \\
\text { Cont. }\end{array}$ & $\begin{array}{l}0.0(0.0)^{\alpha} \\
0.0(0.0)^{u}\end{array}$ & $\begin{array}{l}3.1(4.2) \\
0.02(3.5)\end{array}$ & $\begin{array}{l}1.1(1.7) \\
0.1(0.3)\end{array}$ & $\begin{array}{l}P=8.29 \\
d f=2.102 \\
p<0.001\end{array}$ \\
\hline & $\begin{array}{l}\text { pain-focused } \\
\text { (range:-8-8 })^{y}\end{array}$ & $\begin{array}{l}\text { Exp. } \\
\text { Cont. }\end{array}$ & $\begin{array}{l}0.0(0.0)^{4} \\
0.0(0.0)^{4}\end{array}$ & $\begin{array}{l}1.7(2.2) \\
-0.2(1.04)\end{array}$ & $\begin{array}{l}1.1(1.7) \\
0.1(0.3)\end{array}$ & $\begin{array}{l}F=17.13 \\
d f=2.103 \\
p<0.001\end{array}$ \\
\hline Qualily & $\begin{array}{l}\text { general } \\
\text { (range:-26- } 26)^{N}\end{array}$ & $\begin{array}{l}\text { Exp. } \\
\text { Cont. }\end{array}$ & $\begin{array}{l}0.0(0.0)^{4} \\
0.0(0.0)^{4}\end{array}$ & $\begin{array}{l}2.6(4.3) \\
0.3(0.8)\end{array}$ & $\begin{array}{l}2.3(4.6) \\
0.5(1.3)\end{array}$ & $\begin{array}{l}F=8.31 \\
d f=2,103 \\
P<0,001\end{array}$ \\
\hline & $\begin{array}{l}\text { pain-focused } \\
(\text { range:-8 }-8)^{2}\end{array}$ & $\begin{array}{l}\text { Exp. } \\
\text { Cont. }\end{array}$ & $\begin{array}{l}0.0(0.0)^{4} \\
0.0(0.0)^{4}\end{array}$ & $\begin{array}{l}1.6(2.1) \\
0.03(0.2)\end{array}$ & $\begin{array}{l}1.0(1.8) \\
0.03(0.4)\end{array}$ & $\begin{array}{l}F=15.89 \\
d S=2.103 \\
p<0.001\end{array}$ \\
\hline
\end{tabular}

\footnotetext{
"With statistical adjustrmen for 'Hospital'.

Square rool transformed scores.

y The mast favorable scores are ondertined.

"In actuality. there was no $\mathrm{T} 1$ measuremem for this dimension. As, however. a change in relzion to T'1 is required at $\mathrm{T} 2$ and $\mathrm{T}$, a value of 0 was supplied for $\mathrm{T} 1$.
}

Nurses of the experimental wards also showed an increase in the duration of pain-focused psychosocial interventions (see Table 7.2). This increase is greatest soon after the program (T1). Control nurses demonstrate no obvious change, neither in the short nor the long term. There is a significant difference in trend between both groups of nurses, and the conclusion is that the program resulted in an increase in the duration of pain-focused psychosocial interventions.

Quality. Table 7.2 shows an increase in the quality of experimental nurses' general psychosocial interventions. An obvious increase in the quality of control nurses' general psychosocial interventions can not be seen at none of the measurement points. Testing discloses that there is a significant difference in trend between the two groups of nurses. It can therefore be stated that the program led to an increase in the quality of general psychosocial interventions.

Experimental nurses demonstrate an increase in the quality of their pain-focused psychosocial interventions as well (see Table 7.2); this increase is also most obvious soon after the program (T2). Control nurses do not show any apparent increase, neither in the short nor long term. The difference in trend between experimental and control nurses is significant. Consequently, it can be concluded that the program also led to an increase in the quality of pain-focused psychosocial interventions. 


\section{Chapter 7}

\section{Physical and relaxation interventions}

Number. Numbers of physical and relaxation interventions vary somewhat over the three measurement points, among experimental as well as control nurses (see Table 7.3).

Table 7.3. Mean scores on dimensions of phytical and relaxation inderventions (SD's are between brackets). tested with MANCOVA for repeated measures ${ }^{2}$

\begin{tabular}{|c|c|c|c|c|c|}
\hline $\begin{array}{l}\text { Physical and relaxation } \\
\text { interventions }\end{array}$ & Condition & TI & $\mathrm{n} 2$ & $\mathrm{~T} 3$ & $\begin{array}{l}\text { Condition } x \\
\text { measuremeal point }\end{array}$ \\
\hline $\begin{array}{l}\text { Number } \\
\text { (range: } 0-8.9)^{2 *}\end{array}$ & $\begin{array}{l}\text { lexp. } \\
\text { Cens. }\end{array}$ & $\begin{array}{l}5.2(1.4) \\
5.0(1.6)\end{array}$ & $\begin{array}{l}5.4(1.3) \\
5.1(1.7)\end{array}$ & $\begin{array}{l}5.2(1.4) \\
4.8(1.6)\end{array}$ & $\begin{array}{l}F=0.21 \\
d f=2,103 \\
p=0.40\end{array}$ \\
\hline $\begin{array}{l}\text { Quality } \\
\text { (range: }-12-(2)^{4}\end{array}$ & $\begin{array}{l}\text { Exp. } \\
\text { Cont. }\end{array}$ & $\begin{array}{l}0.0(0.0)^{\omega} \\
0.0(0.0)^{\omega}\end{array}$ & $\begin{array}{l}1.89(2.4) \\
0.0(0.0)\end{array}$ & $\begin{array}{l}1.09(2.1) \\
0.06(0.3)\end{array}$ & $\begin{array}{l}F=18.98 \\
d f=2.103 \\
p<0.001\end{array}$ \\
\hline
\end{tabular}

\footnotetext{
"With statistical adjustment for 'Hospiar".

2 Square root Iranuformed scores.

The mosil favorable scores are underlinod.

"In actuality, there was no $\mathrm{T}$ measurement for this dimension. As, bowever, a change in relation $w \mathrm{~T} 1$ is required al $T 2$ and $\mathrm{T}$. a value of 0 was supplied for $\mathrm{Tl}$.
}

However, the nonsignificant difference in trend between experimental and control nurses indicates that the number of physical and relaxation interventions is not affected by participation in the program.

Quality. Experimental nurses do show an increase in the quality of their physical and relaxation interventions (see Table 7.3). There is virtually no change in the quality of physical and relaxation interventions of control nurses. The difference in trend between the two groups is significant, and it can be concluded that the program had a positive effect on the quality of physical and relaxation interventions.

\section{Discussion}

As described, no effects were ascertained on the number of psychosocial intenventions. A possible explanation for this is that nurses who participated in the program may evaluate their own interventions more critically than previously, in which case a greater number of interventions would not always be expressed in the scores (Sprangers, 1988). Pool (1983) proposed a similar hypothesis when he was also unable to discern much change in the number of psychosocial interventions after a communication program. However, if the scores do reflect the actual situation, the lack of increase in the number of psychosocial interventions may be connected to the lack of change in nurses' attitudes towards these interventions. In addition, the lack of increase in number may also be connected to the increase in quality of psychosocial interventions. Carrying out high-quality interventions, rather than a large number of interventions, may be a priority for nurses. In the Adjusted Therapeutic Behavior Scale nurses indicated changes concerning quality of psychosocial interventions with written comments such as: "I project my own ideas onto patients less 
now", "I pay more attention to patients' emotions and experiences, and go into them in greater depth", "I now involve patients more when providing information", "I provide more comprehensive information, for instance about the reasons for treatment".

The program also resulted in an increase in the duration of psychosocial interventions. An increase in duration can be considered as positive in view of studies indicating that psychosocial interventions (e.g. in the form of bedside talks) are often brief and superficial (Armstrong-Esther et al., 1994; Maes, 1988).

Although the program positively affected nurses' attitudes towards physical and relaxation interventions, the number of these interventions did not change. This finding may be explained by findings from qualitative interviews with program participants (see Chapter 10), which indicated that nurses did not feel able to put physical and relaxation interventions frequently and regularly into practice. Among other factors, insufficient familiarity with massage, relaxation and distraction techniques, limited time and personnel, and a lack of formal implementation were stated as reasons.

However, the quality of physical and relaxation interventions did improve due to participation in the program. In the Physical and Relaxation Interventions Questionnaire, nurses provided descriptions of these changes in quality, such as: "My information to the patient about these interventions is better and more thorough now", "I now demonstrate (relaxation) exercises myself", "I now ask patients what the effects of these interventions are".

Although all the positive effects diminished somewhat with time, they were still observable at the last measurement point. This is an indication that nurses have retained what they learned and integrated it in daily practice.

An especially important question is whether the reported positive effects give a just picture of the actual effects of the pain CE program (see also 'General Discussion'). It is possible that nurses in the experimental condition felt a social duty to indicate that 'they did something with the course', resulting in socially desirable answers. In addition, 'selective memory effects' may have influenced the scores of the self-report questionnaires. However, Chapter 9 of this dissertation will show that patients' pain intensity was significantly lower among those attended by nurses who had completed the program than among those cared for by control nurses. This suggests that nurses' pain interventions have indeed improved, as reflected in the lower pain intensity scores. It is, however, not completely clear whether the decrease in pain intensity can be attributed to the changes in nonpharmacological interventions described in this chapter or to changes in pharmacological interventions (described in Chapter 8). Accordingly, an interesting question for future research is whether changes in nurses' nonpharmacological interventions are reflected in patients' satisfaction regarding these interventions. And, if so, whether this is connected to a decrease in pain intensity.

\section{References}

Ajzen I (1988). Attitudes, personality, and behavior. Milton Keynes: Open University Press.

Armstrong-Esther CA. Browne KD \& McAfee JG (1994). Elderly patients: still clean and sitting quietly. Joumal of Adwanced Nursing 19, 264-271.

Bartour LA, McGuire DB \& Kirchoff KT (1986). Nonanalgesic methods of pain control used by cancer outpatients. Oncology Nursing Forum 13, 6, 56-60. 
Bensing JM (1992). Emoties in de wijkverpleging: hoe vind je de juiste balans? Maatschappelijke Gezondheidszorg, Thuiszorg en Preventie, 12, 6-8.

Cook JD (1986). Music as an intervention in the oncology setting. Cancer Nursing 9, 1, 23-28.

Daiton JA (1989). Nurses' perceptions of their pain assessment skills, pain management practices, and attirudes toward pain. Oncology Nursing Forum 16, 2, 225-231.

Derks W (1991). Inventarisatie van het verpleegprobleem pijn. Opvattingen en toepassingen van maatregelen door verpleegkundigen in Nederland, Unpublished Master thesis. Maastricht: University of Limburg.

Devine EC \& Cook TD (1983). A meta-analytic analysis of effects of psycho-educational interventions on length of postsurgical hospital stay. Nursing Research 32, 267-274.

Devine EC \& Cook TD (1986). Clinical and cost-saving effects of psycho-educational interventions with surgical patients: a meta-analysis. Research in Nursing and Health 9, 89-105.

Faulkner A (1992). The evaluation of training programmes for communication skills in palliative care. Journal of Cancer Care, 1, 75-78.

Fordham M \& Dunn V (1994). Alongside the person in pain. Holistic care and nursing practice. London, Philadelphia, Toronto, Sydney, Tokyo: Baillere Tindall.

Francke AL (1992). Wat doen verpleegkundigen bij pijn? Tijdschrift voor Ziekenverpleging 102, 13, 460463.

Francke AL, Huijer Abu-Saad H \& Grypdonck M (1995). Pain assessment and management in surgical cancer pacients. Pilot and evaiuation of a continuing education program. Joumal of Continuing Education in Nursing 26, 5, 214-218.

Halfens R Derks W \& Huijer H (1994). Verpleegkundige pijninterventies in Nederlandse ziekenhuizen. Een inventarisatie van opvattingen en praktijk. Verpleegkunde. Nederlands-Vlaams Tijdschrift voor Verpleegkundigen 8, 4, 243-250.

Hathaway D (1986). Effect of preoperative instruction on post-operative outcomes: a meta-analysis. Nursing Research 35, 269-275.

Herr KA \& Mobily PR (1992). Interventions related to pain. Nursing Clinics of North America 27, 2, 347 368.

Hyman RB, Feldman HR, Harris RB, Levin RF \& Malloy GB (1989). The effects of relaxation training on clinical outcomes: a meta-analysis. Nursing Research 38, 4, 216-221.

Kuiper M de (1991). Nurses' perceptions of their pain assessment skills, pain management practices and attitudes towards pain. Unpublished master thesis. Wales: University of Wales.

Levin RF, Malloy GB \& Hyman, RB (1987). Nursing management of postoperative pain: use of relaxation techniques with female cholecystectomy patients. Joumal of Advanced Nursing 12, 4, 463-472.

Linde MJ van der (1994). Het verpleegprobleem pijn bij terminale patiënten met kanker in de thuissiruatie. Versiagboek van het I3e Congres van de Vereniging van Oncologie Verpleegkundigen, 75-78.

Locsin RGRAC (1981). The effect of music on the pain of selected post-operative patients. Joumal of Advanced Nursing 6, 19-25.

Maes H (1988). De communicatie tussen patiënt en student-verpleegkundige; een exploratief onderzoek. Unpublished master thesis. Louvain: Catholic University.

Maguire P (1985). Barriers to psychological care of the dying. British Medical Journal, 1711-1713.

McCaffery M \& Beebe A (1989). Pain. Clinical Manual for Nursing Practice. St. Louis-BaltimorePbiladelphia-Toronto: The C.V. Mosby Company.

Mumford E. Schlesinger HJ \& Glass G (1982). The effects of psychological intervention on recovery from surgery and heart attacks: an analysis of the literature. American Journal of Public Health 72, 2. $141-151$.

Northouse PG \& Northouse LL (1887). Communication and cancer. Issues confronting patients, health professionals and family members. Joumal of Psychosocial Oncology 5. 3, 17-46.

Pool JJ (1983). Sociaal-therapeutisch gedrag van verpleegkundigen. Academisch proefschrift. Amsterdam: Vrije Universiteit.

Razavi D, Delvaux N, Farvacques C \& Robaye (1988). Inmediate effectiveness of brief psychological training for health professionals dealing with terminally ill cancer patients: a controlled study. 
Social Science \& Medicine 27, 4, 369-375.

Schrameijer F \& Brunenberg (1992). Psychosociale zorg bij kankerpatiënten. Patiënten en hulpverleners over problemen en hulpaanbod. Utrecht: Nederlands Centrum Geestelijke Volksgezondheid.

Schuurmans J. Wulferink A \& Boer H (1993). Pijn bij kanker: Opvattingen van verpleegkundigen. Tijdschrifi voor Ziekenverpleging 103, 3, 97-99.

Shade P (1992). Patient-controlled analgesia: can client education improve outcomes? Joumal of Advanced Nursing 17, 408-413.

Sprangers M (1988). Response shift and the retrospective pretest. On the usefulness of retrospective pretestposttest designs in detecting training related response shift. $\mathrm{PhD}$-thesis. The Hague. The Netherlands: lustitute for Education Research SVO.

VWR/CBO (1994). Syllabus bij de consensusbijeenkomst 'Verpleegkunde bij pijn'. Utrecht: CBO.

Wells $N$ (1982). The effect of relaxation on postoperative muscle tension and pain. Nursing Research 31,4 , 236-238. 
CHAPTER 8 Effects of the program on nurses' pharmacological pain management

This chapter is an adapted version of an article submitted for publication.

Authors: AL Francke, WA Dingemans, PAJ Borg, JB Luiken, H Huijer Abu-Saad \& M Grypdonck. 


\section{Effects of the program on nurses' pharmacological pain management}

\section{Summary}

This chapter focuses on the effects of the pain CE program on nurses' pharmacological pain management. Using a pretest-posttest control group design, it was found that participation in the program led to an increase in nurses' knowledge of pain medication, to an increase in the quantity of nonopioids administered, and to an improvement of the quality of analgesic administrations. The program did not, however, result in significant changes in the quantity of opioid analgesics and local anaesthetics administered.

\section{Introduction}

Nurses have partial responsibility for adequate pharmacological pain management. They can influence physicians' prescriptions by giving information about patients' pain and analgesic needs. Furthermore, particularly in case of 'as needed' prescriptions, they often decide the frequency and amount of administration (Ferrell et al., 1991). Unfortunately, physicians often prescribe less analgesics than needed, and the quantities of medication patients actually receive from nurses are often even less (Closs, 1990; Donovan, 1990; Lavies et al., 1992; Lindley et al., 1990; McLeod et al., 1995).

Gaps in nurses' knowledge concerning effective dose ranges and duration of action, plus unfounded fear of side effects may affect this inadequate pain management (see Chapter 3; Ferrell et al., 1991; Fothergill-Bourbonnais \& Wilson-Barnett, 1992; Mackintosh, 1994; McCaffery \& Ferrell, 1992; Paice et al. 1991). Several studies established that these gaps in knowledge may decrease when nurses participate in CE on pain (Hauck, 1986; Ferrell et al., 1993, Myers, 1985; Westfall \& Speedie, 1981). In addition, it was established that patients hospitalized after nursing CE programs, received more analgesics, particularly during the early postoperative period (Degner et al., 1982; Foglesong, 1983; Foglesong et al., 1987; Sofaer, 1984). However, statistical significance was demonstrated in only three of the mentioned studies (Myers, 1985; Westfall \& Speedie, 1981; Sofaer, 1984), while the other studies leave us in the dark in this respect. In addition, none of the studies reports whether the quality (not only the quantity) of analgesic administrations increased. Further research in this area is recommended, and, therefore, this chapter focuses on the following research questions. Does the CE program result in:

1. an increase in nurses' knowledge of analgesics?

2. an increase in the quantity of analgesics administered?

3. an improvement of the quality of analgesic administrations?

\section{Methods}

Design. Effects of the program were measured in a pretest-posttest control group design, with randomization at ward level. Nurses from both conditions filled in a set of questionnaires at three measurement points: T1, T2, T3 (see Chapter 6 and Figure 8.1). 
Data from patients were collected in two measurement periods:

0-3 months before the program (period M1);

3-6 months after the program (period M2).

lach period took three months (see Figure 8.1), since this time span was necessary to recruit sufficient patients:

Figure 8.1: Measurement points in nurses and measurement periods in patients

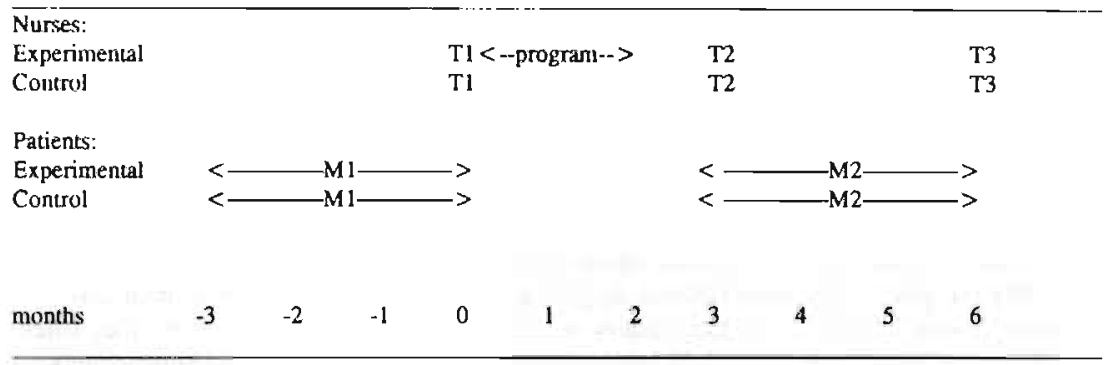

Sample. In each of the five participating hospitals, two surgical wards were involved. The effects of the program were determined on the basis of data from the 106 nurses who remained in the study until the last measurement point.

In addition, the program's effectiveness was measured among 152 patients meeting the inclusion criteria 'being hospitalized for a curative resection of colon or breast cancer' and 'having a life expectancy of more than six months'. Measurements were restricted to only two patient categories (surgical colon and breast cancer patients) to increase internal validity (Rothman, 1986; Francke \& Duivenvoorden, 1993). These two patient categories were particularly selected because of the high prevalence of colon and breast cancer, facilitating patient recruitment. Another reason for this selection was that the surgical treatment of colon and breast cancer often involves pain (Dorrepaal, 1989; Daut \& Cleeland, 1982). The 152 patients who participated in the study were spread over four groups:

- a group admitted to the experimental wards in period M1;

- a group admitted to the experimental wards in period M2. This group concerned the patients attended by nurses after the CE program;

a group admitted to the control wards in period $\mathrm{Ml}$;

- a group admitted to the control wards in period M2.

All the patients who met the inclusion criteria and who were hospitalized in the two measurement periods (M1 and M2) were asked to participate by head nurses or other nurses responsible for patient care. These nurses suggested that refusal to cooperate were less than 10\% (see 'Discussion' in Chapter 10). None of the patients who consented to participate in the study dropped out.

In Chapter 6 (Table 6.1) and Chapter 9 (Table 9.1) more information is given about background characteristics of nurses and patients, respectively. 
Program. Major program items were: a) pain and the assessment of pain, b) psychosocial interventions, c) physical and relaxation interventions, and d) pharmacological pain management.

Within the framework of pharmacological pain management, relevant literature (Francke, 1992; Schulkes-Van der Pol, 1990) on types, mode of action and effects of opioids and nonopioids was provided and discussed. In addition, attention was paid to the rationale of scheduled analgesics and actual risks of side-effects (like breath depression, addiction and constipation). Furthermore, nurses' responsibilities and tasks with respect to pain medication (e.g. analgesic administration, report and documentation of analgesic needs and effects) were discussed in the group as a whole and in small groups. Content, educational method and other characteristics of the program are described in more detail in Chapters 4 and 6 and in Appendix I.

Instrument for nurses. The Questionnaire on Knowledge of Analgesics was used to measure nurses' knowledge with regard to types, mode of action, effects, side-effects and prescriptions of opioids and nonopioids. All items were followed by the same three answer categories. See, for example, the following (translated) item:

On average intramuscular opioids are 6,5 hours active

0 true

0 not true*

0 do not know

$\left(^{*}=\right.$ correct answer $)$

The questionnaire was developed by the researcher because existent instruments (e.g. Heyde, 1991; Chapman et al. 1987; Cohen, 1980; Derks, 1991; Fothergill-Bourbonnais \& Wilson-Barnett, 1992; McCaffery et al., 1990; McCaffery \& Ferrell, 1992; WattWatson, 1987; Weis et al., 1983) did not fit with the program content or did not meet methodological criteria. Eight pain experts established the new questionnaire's content validity. The questionnaire was tested on fifteen nurses who did not participate in other parts of the study. The questionnaire's items were spread over three subquestionnaires. The expectation was that by using different subquestionnaires at the three measurement points, test effects (as a result of repeated measures) would be reduced. Principal component analysis for ordinal data was executed using the data of the 106 research subjects in the intervention study. It appeared that items within each subquestionnaire showed little clustering, and therefore subquestionnaires were not further divided into dimensions. For additional psychometric information on validity and reliability, see the manual of the Questionnaire on Knowledge of Analgesics (available on request). 


\section{Chapter 8}

Rating the quality of analgesic prescriptions and administrations. Two pain specialists ${ }^{32}$ independently rated for each patient, and for each of the first five postsurgical days separately, the 'Quality of analgesic prescriptions' (see research question 3), and the 'Quality of analgesic administrations' (see section 'Statistical analysis'). In the rating process they took into account information on analgesics administered and prescribed, and several patient characteristics, namely: pain intensity, pain duration, number of sleepless hours as a result of pain, state anxiety, mood disturbances, age, and type of surgery. Point of departure for both raters were the following questions:

- (taking into account the aforementioned patient characteristics) is the type of analgesic adequate?

- $\quad$ is the amount adequate (per administration and per day)?

- $\quad$ is the frequency of administration adequate?

- $\quad$ is the method of administration adequate?

Both raters employed current views on adequate pharmacological pain management, as expressed by the IASP (1992) and Rawal and Berggren (1994), as a reference basis. Similar to the latter authors, the raters considered a pain intensity score of 3 or higher (within a range of $0-10$ ) as a main indication of inadequate pain relief.

Ratings were displayed on a scale of $O(=$ very bad quality of prescriptions or administrations) to 5 (=very good quality of prescriptions or administrations). 'Can not be rated' could be marked if information on analgesics prescribed and administered, or on patient characteristics was considered insufficient. The rating was done blindly, in that the raters had not received any information on the patients' (experimental or control) condition, measurement period or hospital.

The following method was used by the researcher to calculate the final quality scores (to be used in the statistical analyses):

when one of the two raters marked the 'can not be rated' category, this score was coded as 'missing',

- when the absolute discrepancy between the raters' scores amounted to more than two, the rating was also coded as 'missing'.

the two raters' scores were then averaged per day and per patient.

Instruments for patients. Several valid and reliable questionnaires were used to gather the information on the aforementioned patient characteristics. To begin with, pain intensity was measured with the single item Numerical Rating Scale (Scott \& Huskusson, 1976) which ranges from 0 (no pain at all) to 10 (worst pain). Two relevant items of the Durch version (Verkes et al., 1989) of the McGill Pain Questionnaire Quality of Life-scale (Melzack, 1975) were used to measure pain duration and the number of sleepless hours as a result of pain. State anxiety was determined by four items of the Dutch version (Van der Ploeg et al., 1980) of the State-Trait Anxiery Inventory (Spielberger et al., 1970). It is appropriate to select a few items when research requires repeated measures (Van

n. One amaesthesiologist and one neurologist, both working in a pain center at two different university hospitals. 
Knippenberg et al., 1990). In this study the items 1, 3, 5 and 17 from the state anxiety scale were selected. These items are mentioned by Van der Ploeg et al. (1980) as suitable when a selection must be made. Finally, the Dutch, shortened adaptation (Wald \& Mellenbergh, 1990) of the Profile of Mood States (McNair et al., 1971) was used for measuring mood disturbances (depression, anger, fatigue, vigor, and tension respectively).

Information about age, type of surgery, and analgesics prescribed and administered was derived from patient files.

Data collection procedures. Patients were visited in the hospital (about 4.00 p.m.) the day before and two and four days after surgery. The researcher used the questionnaire formats to obtain data from patients. All relevant parts of the patient files were copied after the patients were discharged from the hospital for the patient file audit.

Data collection procedures among nurses are described in Chapter 6.

Conversion of dosages of analgesics. Four categories of pain medication were distinguished to determine 'Quantity of analgesics administered' (see research question 2) and 'Quantity of analgesics prescribed' (see section 'Statistical analysis'). These categories were: 1) spinal opioids, 2) spinal local anaesthetics, 3) intramuscular opioids and 4) (rectal or intramuscular) nonopioids. No other categories were distinguished because the analgesics concerned were not -or rarely- used in the sample investigated.

To improve the comparability of the different opioids, 24-hour dosages were converted into the number of 'Morfine $10 \mathrm{mg}$-equivalent dosages'. Spinal local anaesthetics' 24-hour dosages were expressed in milligrams. Nonopioids' 24-hour dosages were converted into the number of standard dosages (rather diverse nonopioids having various working mechanisms were used and, consequently, computation of equivalent dosages or milligrams was not indicated).

Statistical analyses. Effects of the program on 'Knowledge of analgesics' were determined by MANCOVA for repeated measures with statistical adjustment for 'Hospital'. Multivariate testing was performed for the 'interaction between condition and measurement point'.

Effects on 'Quantity of analgesics administered' and 'Quality of analgesic administrations' were determined by ANCOVA for repeated measures. Repeated measures ANCOVA, instead of MANCOVA, was performed because we were primarily interested in trends across the two measurement periods (across M1 and M2) and less interested in those across the several measurement points within a measurement period. Testing took place for the 'interaction between condition and measurement period', and for the 'interaction between condition, measurement period and patient category'. The first mentioned interaction was tested to determine whether there was a significant difference in trend (across M1 and M2) between experimental and control patients. The latter interaction was tested to determine whether patient category was related to a possible difference in trend over time. Statistical adjustments were made for several covariates (see below Tables 8.2, 8.3, 8.4 and 8.5), all combined in a multivariate confounder score (Miettinen, 1985). 


\section{Chapter 8}

In the case of 'Quantity of analgesics administered' testing was performed once with and once without adjustment for 'Quantity of analgesics prescribed' (see Tables 8.2, 8.3 and 8.4$)$. In the case of 'Quality of analgesic administrations' a comparable strategy was used, and effects were tested once with statistical adjustment for 'Quality of analgesic prescriptions' and once without that adjustment (see Table 8.5). The aforementioned adjustments for 'Quantity of analgesics prescribed' and 'Quality of analgesic prescriptions' seemed appropriate because autonomous prescriptions of doctors may influence administrations by nurses. However, nurses may affect physicians' prescriptions (e.g. by giving information about patients' analgesic needs) which in turn may affect nurses' administrations. In the latter case, adjustments for 'Quantity of analgesics prescribed' and 'Quality of analgesic prescriptions' are not appropriate. Analyses were performed once with, and once without, the aforementioned adjustments because it was impossible to determine beforehand whether or not nurses affected doctors' prescriptions. For all outcome variables one-sided testing was applied with a significance level of 0.05 .

\section{Results}

\section{Knowledge of analgesics}

Experimental nurses' knowledge of pain medication was higher after than before the CE program (see Table 8.1). This increase in knowledge was more apparent six months after the conclusion of the program than after one month. Control nurses' knowledge scores fluctuated somewhat across the three measurement points (see Table 8.1). The difference in trend over time between experimental and control nurses was significant (see Table 8.1). The conclusion is that the CE program on pain led to more knowledge of pain medication.

Tabie 8.1. Mean scores on 'Knowledge of analgesics' (SD's are between brackets), lested with MANCOVA for repeated measures".

\begin{tabular}{|l|l|lll|l|}
\hline & Condition & T1 & T2 & $T 3$ & $\begin{array}{l}\text { Condition } x \\
\text { measurement point }\end{array}$ \\
\hline $\begin{array}{l}\text { Knowledge } \\
\text { of analgesics } \\
\text { (range 0.9) }\end{array}$ & Exp. & $4.1(1.7)$ & $5.0(1.3)$ & $5.9(2.0)$ & $\begin{array}{l}\mathrm{F}=10.11 \\
\mathrm{df}=2.103 \\
\mathrm{p}=0.001\end{array}$ \\
\hline
\end{tabular}

\footnotetext{
"With statistical adjustment for 'llospical'.

The most favorable scores are underiined.
} 
Quantity of analgesics administered. In the sample investigated, spinal opioids were administered only to colon patients, never to breast patients. More (equivalent) dosages of spinal opioids were administered to colon patients after the program, in both the experimental and control condition (see Table 8.2). No significant difference in trend across the measurement periods appeared between experimental and control patients.

In all cases, spinal opioids were administered in an infusion pump in combination with local anesthetics. There was an increase in the quantities of local anaesthetics administered across the two measurement periods on both the experimental and control wards. Again trends in experimental and control patients did not differ significantly (see Table 8.2).

Table 8.2. Mean scores on 'Quantity of spinal opioids administered' and 'Quantity of spinal local ancsilyctics administered' (SD's are between brackets.), tested with ANCOVA for repealed measures.

\begin{tabular}{|c|c|c|c|c|c|c|}
\hline & Day & Condition & M1 & $M 2$ & $\begin{array}{l}\text { Conditio } \\
\text { with }\end{array}$ & $\begin{array}{l}\text { uremend period } \\
\text { without }\end{array}$ \\
\hline $\begin{array}{l}\text { Quantity of } \\
\text { spinal opioids } \\
\text { administered }\end{array}$ & $\begin{array}{l}\text { day } 0 \\
\text { day } 1 \\
\text { day } 2 \\
\text { day } 3 \\
\text { day } 4\end{array}$ & $\begin{array}{l}\text { exp. } \\
\text { cont. } \\
\text { exp. } \\
\text { cont. } \\
\text { exp. } \\
\text { cont. } \\
\text { exp. } \\
\text { cont. } \\
\text { exp. } \\
\text { cont. }\end{array}$ & $\begin{array}{l}1.9(4.1) \\
1.9(4.0) \\
1.9(4.1) \\
1.5(4.0) \\
1.0(2.7) \\
0.4(1.7) \\
0.5(2.1) \\
0.0(0.0) \\
0.0(0.0) \\
0.0(0.0)\end{array}$ & $\begin{array}{l}3.6(5.9) \\
4.8(7.0) \\
3.8(6.5) \\
4.8(0.0) \\
2.1(2.9) \\
3.0(5.1) \\
1.3(1.9) \\
1.1(2.2) \\
0.1(0.3) \\
0.3(1.1)\end{array}$ & $\begin{array}{l}F=0.77 \\
D r=1 \\
F=0.19\end{array}$ & $\begin{array}{l}F=0.73 \\
d f=1 \\
p=0.20\end{array}$ \\
\hline $\begin{array}{l}\text { Quantity of } \\
\text { spinal local } \\
\text { aneathetics } \\
\text { sdministered }\end{array}$ & $\begin{array}{l}\text { day } 0 \\
\text { day } 1 \\
\text { day } 2 \\
\text { day } 3 \\
\text { (ia) } 4\end{array}$ & $\begin{array}{l}\text { exp. } \\
\text { cont. } \\
\text { exp. } \\
\text { cont. } \\
\text { exp. } \\
\text { cont. } \\
\text { exp. } \\
\text { cont. } \\
\text { exp. } \\
\text { cont. }\end{array}$ & $\begin{array}{l}45.3(83.6) \\
18.6(47.9) \\
45.3(83.6) \\
17.3(47.2) \\
18.0(37.4) \\
5.33(20.6) \\
6.6(2.6) \\
0(0) \\
0(0) \\
0(0)\end{array}$ & $\begin{array}{l}70.0(77.7) \\
48.5(74.7) \\
71.8(81.7) \\
48.4(74.7) \\
40.0(49.1) \\
26.1(43.5) \\
31.8(41.9) \\
7.6(15.8) \\
10.9(36.1) \\
0.7(2.7)\end{array}$ & $\begin{array}{l}F=0.16 \\
D r=1 \\
p=0.35\end{array}$ & $\begin{array}{l}F=10.18 \\
d f=1 \\
p=0.33\end{array}$ \\
\hline
\end{tabular}

"With = with statistical adjustument for "Quantity of analgesics, prescribed. "Pain intensity score for the day before surgery',

'Slate anxiey score for the day defore surgery'. 'Hospital'. 'Type of surgery'. 'Agc'. 'Sex', and 'Number of days in intensive care'

"' Without = with statistieal adjustment for all covariates mentioned under ". exceps 'Quantity of analgesics prescribed'. 
The quantities of equivalent dosages of intramuscular opioids administered in the first five days after surgery varied considerably across the two measurement periods in both conditions (see Table 8.3). Testing revealed no significant difference in trend between experimental and control patients.

Table 8.3. Mean seores on 'Quantity of intramuscular opioids administered' (SD's are between brackets), Iestod with ANCOVA for repeated measures.

\begin{tabular}{|c|c|c|c|c|c|c|c|c|c|}
\hline & \multirow[t]{2}{*}{$\begin{array}{l}\text { Patient } \\
\text { category }\end{array}$} & \multirow[t]{2}{*}{ Day } & \multirow[t]{2}{*}{ Condition } & \multirow[t]{2}{*}{ M1 } & \multirow[t]{2}{*}{ M2 } & \multicolumn{2}{|c|}{ Condition $x$ period } & \multicolumn{2}{|c|}{$\begin{array}{l}\text { Condition } x \text { period } x \\
\text { patient calegory }\end{array}$} \\
\hline & & & & & & with" & without & with ${ }^{2}$ & withount" \\
\hline $\begin{array}{l}\text { Quantily of } \\
\text { intramuscular } \\
\text { opioids } \\
\text { administered }\end{array}$ & breast & $\begin{array}{l}\text { duy } 0 \\
\text { day } 1 \\
\text { day } 2 \\
\text { day } 3 \\
\text { day } 4 \\
\text { day } 0 \\
\text { day } 1 \\
\text { day } 2 \\
\text { day } 3\end{array}$ & $\begin{array}{l}\text { exp. } \\
\text { cont. } \\
\text { exp. } \\
\text { cont. } \\
\text { exp. } \\
\text { ant. } \\
\text { exp. } \\
\text { cond. } \\
\text { exp. } \\
\text { cont. } \\
\text { exp. } \\
\text { cont. } \\
\text { exp. } \\
\text { cons. } \\
\text { exp. } \\
\text { eont. } \\
\text { exp. } \\
\text { cont. } \\
\text { exp. } \\
\text { cons. }\end{array}$ & $\begin{array}{l}0.8(0.9) \\
0.5(0.5) \\
1.4(2.1) \\
0.6(0.6) \\
0.1(0.5) \\
0.3(0.7) \\
0.2(0.4) \\
0.1(0.3) \\
0.1(0.3) \\
0.0(0.0) \\
0.2(0.4) \\
0.6(0.8) \\
0.07(0.3) \\
0.04(0.2) \\
0.1(0.2) \\
0.03(0.2) \\
0.04(0.2) \\
0.0(0.0) \\
0.03(0.2) \\
0.0(0.0)\end{array}$ & $\begin{array}{l}0.5(0.9) \\
0.4(0.6) \\
0.5(0.9) \\
0.4(0.6) \\
0.5(0.9) \\
0.4(0.9) \\
0.4(0.8) \\
0.1(0.2) \\
0.2(0.5) \\
0.0(0.0) \\
0.5(0.7) \\
0.5(0.5) \\
0.1(0.3) \\
0.3(0.5) \\
0.1(0.3) \\
0.1(0.2) \\
0.0(0.0) \\
0.0(0.0) \\
0.0(0.0) \\
0.0(0.0)\end{array}$ & $\begin{array}{l}F=0.11 \\
D r=1 \\
p=0.37\end{array}$ & $\begin{array}{l}F=0.26 \\
d f=1 \\
p=0.81\end{array}$ & $\begin{array}{l}F=0.45 \\
D r=1 \\
p=0.25\end{array}$ & $\begin{array}{l}F=0.39 \\
d f=1 \\
p=0.27\end{array}$ \\
\hline
\end{tabular}

"With $=$ with statistical adjustment for 'Quancity of analigesics prescribed' 'Pain intensity score for the day before surgery',

'State anxiely score for the day hefore surgery'. 'Hospital'. Type of surgery', 'Age', 'Sex', and 'Number of days in intensive eare'.

2. Without $=$ with satistical adjustment for all covariates mentioned under ". excers 'Quantity of anslgesics preseribed'. 
There was no obvious increase across the two measurement periods in the quantity of nonopioids administered to colon patients, either in the experimental or control condition. However, there was an increase across the two measurement periods in the quantity of nonopioids (rectal or intramuscular) administered to experimental breast patients (see Table 8.4). This difference between the situation before and after the program is most apparent on postsurgical days 1 to 3 (see Figure 8.4). In contrast, in the control condition there were decreases over time in the analgesics administered to breast patients. From statistical testing it appeared that the interaction between condition, measurement period and patient category' was significant when adjustments were made for 'Quantity of analgesic prescriptions' (and almost significant when this adjustment was not made, see Table 8.4). These findings indicate that the program led to an increase in

Table 8.4. Mean scores on 'Quantity of nonopioids administered' (SD's are between brackets), tested with ANCOVA for repeated measures.

\begin{tabular}{|c|c|c|c|c|c|c|c|c|c|}
\hline & \multirow[t]{2}{*}{$\begin{array}{l}\text { Patient } \\
\text { calegory }\end{array}$} & \multirow[t]{2}{*}{ Day } & \multirow[t]{2}{*}{ Condition } & \multirow[t]{2}{*}{ MI } & \multirow[t]{2}{*}{$\mathrm{M} 2$} & \multicolumn{2}{|c|}{ Condition $x$ period } & \multicolumn{2}{|c|}{$\begin{array}{l}\text { Condition } x \text { period } x \\
\text { patient category }\end{array}$} \\
\hline & & & & & & with $^{1 \prime}$ & without & with" & without ${ }^{2}$ \\
\hline $\begin{array}{l}\text { Quantity of } \\
\text { nonopioids } \\
\text { administered }\end{array}$ & breast & $\begin{array}{l}\text { day } 0 \\
\text { day I } \\
\text { day } 2 \\
\text { day } 3 \\
\text { day } 4 \\
\text { day } 0 \\
\text { day } 1 \\
\text { day } 4\end{array}$ & $\begin{array}{l}\text { exp. } \\
\text { cont. } \\
\text { exp. } \\
\text { cont. } \\
\text { exp. } \\
\text { cont. } \\
\text { exp. } \\
\text { cont. } \\
\text { exp. } \\
\text { eont. } \\
\text { exp. } \\
\text { cont. } \\
\text { exp. } \\
\text { cont. } \\
\text { exp. } \\
\text { cont. } \\
\text { exp. } \\
\text { cont. } \\
\text { exp. } \\
\text { cont. }\end{array}$ & $\begin{array}{l}0.1(0.5) \\
0.0(0.0) \\
0.5(1.5) \\
0.0(0.0) \\
0.4(0.7) \\
0.1(0.2) \\
1.1(1.6) \\
0.4(0.9) \\
1.1(1.8) \\
0.5(1.0) \\
0.7(1.5) \\
1.0(1.8) \\
0.9(2.0) \\
1.3(2.1) \\
0.8(2.0) \\
1.2(2.01) \\
0.4(0.9) \\
1.0(2.0) \\
0.6(1.9) \\
1.0(1.9)\end{array}$ & $\begin{array}{l}0.5(1.5) \\
0.2(0.6) \\
0.2(0.9) \\
1.0(1.9) \\
0.5(1.0) \\
1.6(2.4) \\
1.1(2.1) \\
1.6(2.9) \\
1.1(2.1) \\
1.9(2.8) \\
0.8(1.3) \\
0.8(1.4) \\
1.4(2.4) \\
0.8(1.4) \\
1.0(2.3) \\
0.7(1.4) \\
1.0(2.1) \\
0.5(1.1) \\
0.7(1.8) \\
0.5(0.9)\end{array}$ & $\begin{array}{l}F=0.16 \\
D t=1 \\
p=0.34\end{array}$ & $\begin{array}{l}F=0.03 \\
\mathrm{df}=1 \\
p=0.44\end{array}$ & $\begin{array}{l}F=3.19 \\
D f=1 \\
p=0.04\end{array}$ & $\begin{array}{l}F=2.54 \\
d f=r \\
p=0.06\end{array}$ \\
\hline
\end{tabular}

\footnotetext{
"With $=$ with statistical adjustment for 'Quantity of analgesica prescribed' 'Pain intensity score for the day before surgery',

'Stule anxiety score for the day before surgery', 'Hospital'. Type of surgery'. 'Age', 'Sex', and 'Number of days in intensive care'.

"Without $=$ with statistical adjustement for all covariates mentioned under ". excest 'Quantity of analgetics prescribed".
} 


\section{Chapter 8}

the quantity of nonopioid analgesics administered to breast patients, while neither in breast nor in colon patients effects could be established in the quantities of other types of analgesics administered.

Quality of analgesic administrations. The quality of analgesic administrations on the first three days after surgery clearly improved in experimental breast and colon patients across the two measurement periods (see Table 8.5 and Figures 8.3 and 8.4).

Table 8.5. Mean scores on quality of analgesic administnations (SD's are between brackets), tested with ANCOVA for repeated measures.

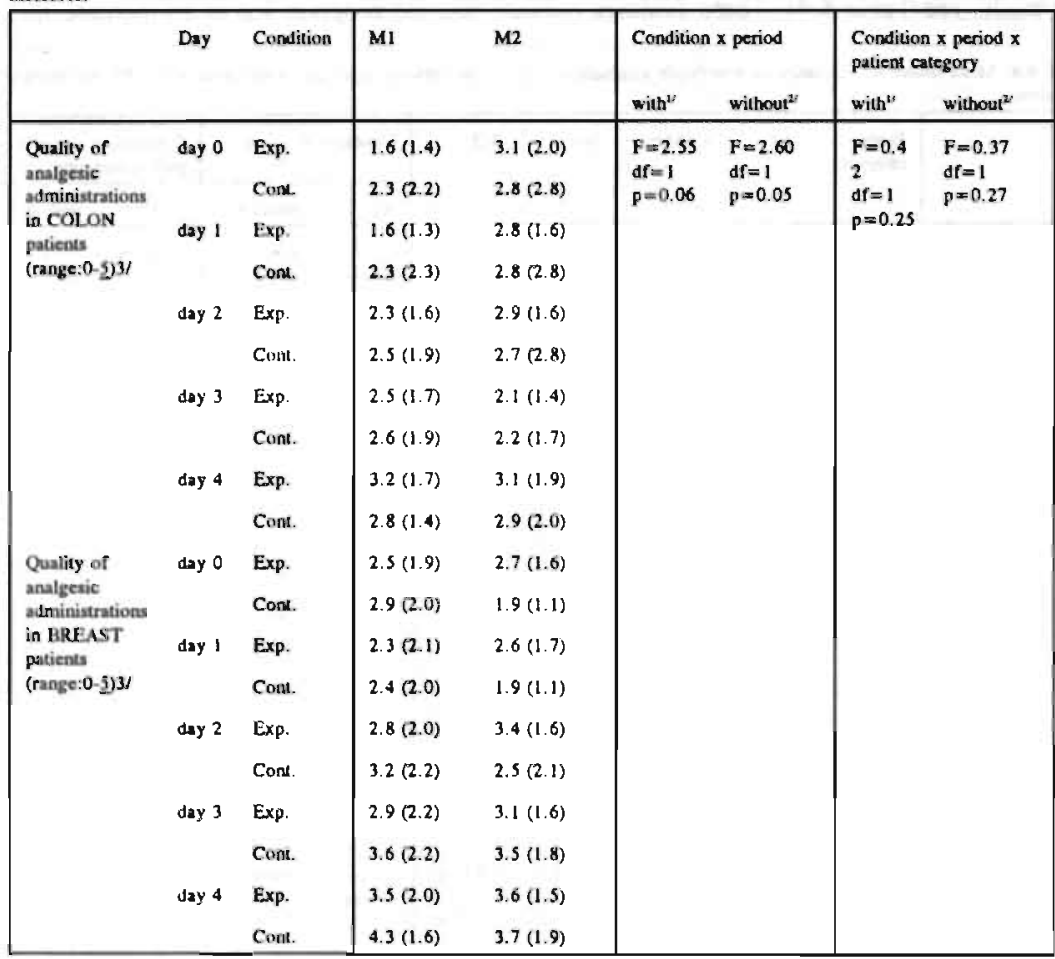

vith $=$ with statistical adjustment for 'Quality of analgesic prescriptions' 'Pain intensity score for the day before surgery'. 'Slate anxiety score for the day before surgery'. 'Hospital'. 'Type of surgery'. 'Ase'. 'Sex' and 'Number of days in intensive care'.

"Without $=$ with statistical adjustmens for all covariates mentioned under", except 'Quality of analgesie prescriptions".

"The most fovorable scorres are undertined. 


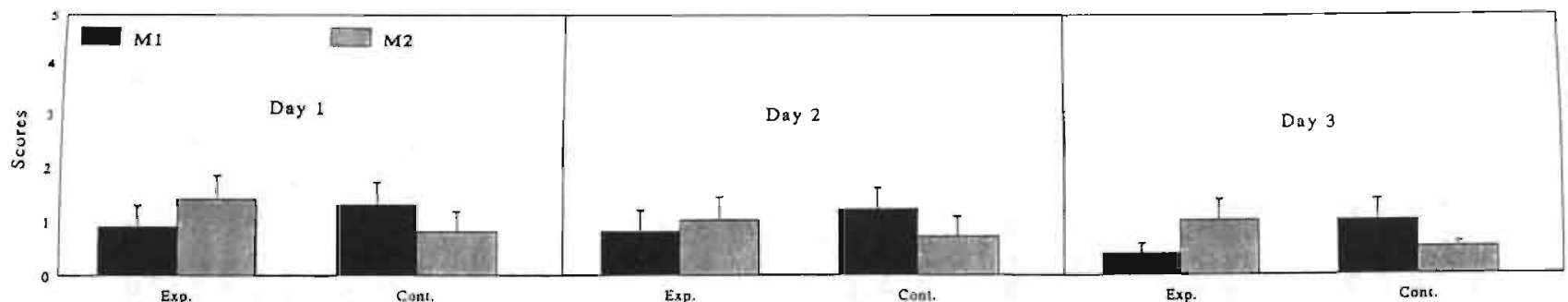

Figure 8.2. Mean (and standard error) of quanity of nonopioids administered to surgical breast cancer patients on postsurgical days 1 to 3.

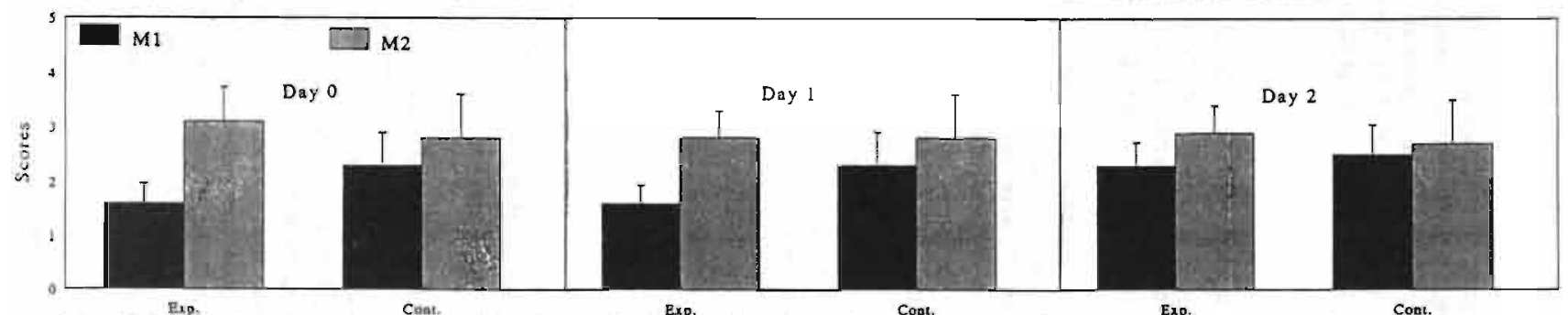

Figure 8.3. Mean (and standard ertor) of quality of analgesic administratons in surgical colon cancer paticnts on postsurgical days 0 to 2.

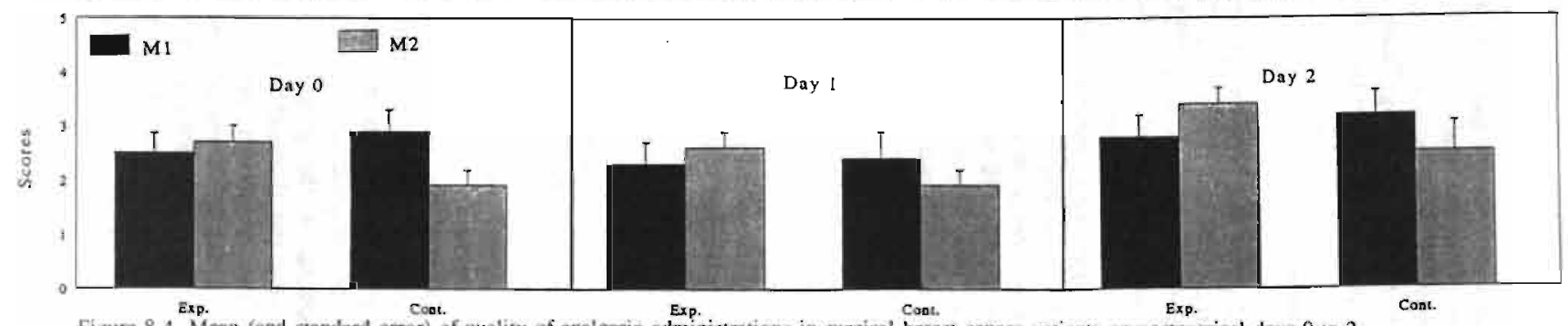

Figure 8.4. Mean (and standard error) of quality of anaigesic administrations in surgical breast cancer patients on postsurgical days 0 to 2. 


\section{Chapter 8}

In control patients the quality of analgesic administrations improved less. With statistical adjustment for the quality of the analgesic prescriptions, there was almost a significant difference in trend between experimental and control patients. Without this statistical adjustment there was a significant difference (see Table 8.5). These findings indicate that the $C E$ program had a positive effect on the quality of analgesic administrations.

\section{Discussion}

It is obvious that program participants have more knowledge of pain medication than nonparticipants (see Table 8.1). This clearly concurs with earlier studies (Hauck, 1986; Ferrell et al., 1993; Myers, 1985; Westfall \& Speedie, 1981), and it can be concluded that continuing pain education for nurses offers a good possibility to bridge gaps in pharmacological knowledge.

Surprisingly, experimental nurses' increase in knowledge was more apparent a half year (T3) than one month (T2) after participation in the program. The fact that the knowledge scores of control nurses at T2 were lower than the scores at $\mathrm{T} 1$ and $\mathrm{T} 3$, suggests that the $T 2$ subquestionnaire on knowledge of analgesics was more difficult than the other two. This might explain why the scores of experimental nurses were higher six months after the program than after just one month. It should therefore be noted that there may be differences in the level of difficulty between the subquestionnaires.

The CE program also led to an increase in the quantity of nonopioids administered to surgical breast cancer patients. No effects of the program could be demonstrated, however, on the quantity of nonopioids administered to surgical colon cancer patients. This finding is not so remarkable, since opioids, and not nonopioids, were usually prescribed in the participating hospitals on the first days after colon surgery. However, neither in surgical colon, nor in breast cancer patients, were there significant effects upon the quantity of opioid analgesics and local anesthetics administered. Although more of these analgesics were administered after the CE program during patients' first postoperative days, the changes in the control wards tended to proceed in the same direction. An explanation for the changes in both conditions could be that pain management is a popular theme in professional journals and congresses. The expertise of professionals may be improved independent of the CE program in the presented study. This improved expertise may be reflected in the increase in quantity of analgesic administrations.

In addition, positive effects of the CE program on the quality of analgesic administrations were established. This improvement may in part be due to the influence of program participants over the medical prescriptions, which may in turn affect the quality of analgesic administrations. Chapter 6 of this dissertation describes that after participating in the program nurses questioned their patients about their pain more extensively and thoroughly than before. It is possible that these nurses relate this new information to doctors, resulting in more adequate prescriptions, and indirectly in an improved quality of analgesic administrations. However, the improvement of quality of administrations may also be caused by a direct influence of program participants; nurses often make autonomous decisions about amount and frequency of particularly nonopioids (Ferrell et al., 1991). 
Still, the increased quality of analgesic administrations does not imply an optimum situation (see scores in Table 8.5, within a range of 0 to 5). In spite of the pleas by pain experts (e.g. IASP, 1992) for scheduled analgesics, most analgesics were still prescribed and administered on an 'as needed' basis in four of the five participating hospitals.

Finally, a recommendation for future research. In earlier studies of CE programs for nurses, no research had been done to discover whether the quality of analgesic administrations improved. Since the rating process of the quality of analgesic administrations also accounted for relevant patient outcomes (e.g. pain intensity and pain duration), we have a more accurate picture than when we looked only at changes in quantities of analgesics administered. The quality of the analgesic administrations may therefore be an important outcome variable in future research on the effects of continuing pain education.

\section{References}

Chapman PJ, Ganendran A, Scoll RJ \& Basford KE (1987). Attitudes and knowledge of nursing staff in relation to management of post-operative pain. Australian and New Zealand Joumal of Surgewns. 57. $447-450$.

Closs SJ (1990). An exploratory analysis of murses' provision of postoperative analgesic drugs. Joumal of Advanced Nursing 15, 42-49.

Cohen FL (1980). Postsurgical pain relief: patients' status and nurses' medication choices. Pain, 9, 265-274

De Conno F. Ripamonti C. Gamba A, Prada A \& Ventafridda V (1989). European Joumal of Surgical Oncology, 15, 242-246.

Degner L, Fujii S \& Levitt M (1982). Implementing a program to control chronic pain of malignant disease in an extended care facility. Cancer Nursing S, 263-268.

Derks W (1991). Inventarisarie van het verpleegprobleem pijn. Opvattingen en toepassingen van matregelen door verpleegkandigen in Nederland. Unpublished Master thesis. Maastricht: University of Limburg.

Donovan MI (1990). Acute pain relief. Nursing Clinics of North America 25, 4, 851-861.

Dorrepaal KL (1989). Pijn bij patienten met kanker. Dissertatie. Amsterdam: Vrije Universiteit.

Ferrell BR, Eberts MT, McCaffery M \& Grant M (1991). Clinical decision-making and pain. Cancer Nursing 14, 6, 289-297.

Ferrel BR. Grant M, Ritchey KJ, Ropchan R \& Rivera LM (1993). The pain resource: nurse training program: a unique approach to pain management. Joumal of Pain and Symptom Mankgement 8. 8 , 549-556.

Foglesong DH (1983). The impact of a staff development offering on mursing practice. Joumal of Continuing Education in Nursing 14, 6, 12-15.

Foglesong DH, Lamber J \& Emerick J (1987). Variables which influence the effect of staff development on nursing practice. Journal of Continuing Education in Nursing 18, 5, 168-171.

Fothergill-Bourbonnais F \& Wilson-Bamett J (1992). A comparative study of intensive therapy unit and hospice nurses" knowledge on pain managernent. Journal of Advanced Nursing 17, 362-372.

Francke AL (1992). Pijn als verpleegprobleem. Dwingeloo: Kavanah.

Francke AL \& Duivenvoorden HJ (1993). Methotologie van interventiestudies. Moeilijkheden, mogelijkheden en walkuilen. In AL Francke (Ed.), Verplegen, intervenieren en evalueren. Verpleegkundig interventie-onderzoek in de praktijk, (pp. 13-23). Lisse: Swets \& Zeitlinger.

Hauck S (1986), Pain: problem for the person with cancer. Cancer Nursing 9, 2, 66-76.

Heyde E (1991). Adehwatheid van verpleegkundige interventies bij postoperatieve pijnbestrijding. Unpublished master thesis. Louvain: Catholic University.

Intemational Association for the Study of Pain (IASP/Ready LB \& Edwards WT, Eds., 1992). Management of acute pain. A practical guide. Task Force on Acute Pain. Seatie: IASP Publications. 


\section{Chapter 8}

Knippenberg FCE, Duivenvoorden HJ, Bonke B \& Passchier J (1990). Shortening the State-Trait Anxiety Inventory. Joumal of Clinical Epidemiology 43, 9, 995-1000.

Lavies N. Hart L, Rounsefell B \& Runciman W (1992). Identification of patient, medical and nursing staff attitudes to postoperative opioid analgesia: stage 1 of a lougitudinal study of postoperative anilgesia. Pain, 48, 313-319.

Lindley CM, Dalton JA \& Fields SM (1990). Narcotic analgesics. Clinical pharmacology and therapeutics. Cancer Nursing 13, 1, 28-38.

Mackintosly C (1994). Do nurses provide adequate postoperative pain relief? British Journal of Nursing 3, 7 , 342-347.

McCaffery M, Ferrell BR, O'Neil Page E, Lester M \& Ferrell B (1990). Nurses' knowledge of opiate analgesics and addiction. Cancer Nursing 13, 1, 21-27.

McCaffery M \& Ferrell BR (1992). Opioid analgesics. Nurses' knowledge of doses and psychological dependence. Journal of Nursing Staff Development 8, 2, 77-84.

Mcleod GA. Davies HTO \& Colvin JR (1995). Shaping attitudes to postoperative pain relief: the role of the acute pain team. Journal of Pain and Symptom Management 10, 1, 30-34.

McNair DM, Lorr M \& Droppleman LF (1971). Edits Manual for the Profile of Mood States. San Diego, California: Educational and Industrial Testing Service.

Meizack $R$ (1975). The MfCGill pain questionnaire: arajor properties and seoriag arethods. Puin, 1, 277-299.

Miettinen OS (1985). Theoretical epidenviology; principles of occurrence research in medicine. New York: Wiley.

Myers JS (1985). Cancer pain: assessment of Durses' knowledge and attitudes. Oncology Nursing Forum 12, 4, 62-66.

Paice JA, Mahon SM \& Faut-Callaban M (1991). Factors associated with adequate pain control in hospitalized postsurgical patients diagnosed with cancer. Cancer Nursing 14, 6. 298-305.

Rawal N \& Berggren L (1994). Organization of acute pain services: a low-cost nodel. Pain, 57, 117-123.

Rloeg HM van der, Defares PB \& Spielberger CD (1980). Handleiding bij de Zelf-Beoordelings Vragenlijst. Een nederlandstalige bewerking van de Spielberger State-Trait Anxiety Inventory. Lisse: Swets \& Zeitlinger B.V.

Rothman KJ (1986). Modern epidemiology. Boston, Massachusatss: Little, Brown and Company.

Schulkes-Van der Pol J (1990). Nederlandse Vereniging ter Bestudering van Pijn. Pijn en pijnbehandeling bij de patient met kanker. Amsterdam: PAL.

Scott J \& Huskusson EC (1976). Graphic representation of pain. Pain, 2, 175-184.

Sofaer B (1984). The effect of focused education for mursing teams on postoperative pain of patients. Dissertation. Edinburgh: University of Edinburgh.

Spielberger CD, Gorsuch RL \& Lushene RE (1970). Manual for the State-Trait Anxiety Inventory. Palo Alto, California: Consulting Psychologists Press.

Verkes R, Vanderiet K, Vertonmen H, Van der Kloot WA \& Van der Meij J (1989). De MPQ-DLV: een standaard nederlandstalige versie van de McGill Pain Questionnaire voor Belgiè en Nederland. In WA van der Kloot \& $\mathrm{H}$ Vertonmen (Eds.). De MPQ-DLV. Een standaard nederlandstalige versie van de McGill Pain Questionnaire. Achtergronden en handleiding (pp. 57-69). Lisse: Swets en Zeitlinger.

Wald FDM \& Mellenbergh GJ (1990). De verkorte versie van de Nederlandse vertaling van de Profile of Mood States (POMS). Nederlands Tijdschrift voor Psychologie, 45, 86-90.

Watt-Watson JH (1987). Nurses' knowledge of pain issues: a survey. Joumal of Pain and Symptom Management 2, 4, 207-211.

Weis OF. Sriwatanakul K. Alloza JL. Weintraub M \& Lasagna L (1983). Artitudes of patients, house staff. and nurses towards post-operative analgesic care. Anaesthesia and Analgesia 62, 70-74.

Westtall LK \& Speedie SM (1981). The effects of inservice education provided by consultant pharmacists on the behavior of nurses in long-term care facilities. Drug Intelligence and Clinical Pharmacy 15, 777-781. 


\section{CHAPTER 9 Effects of the program on patients}

This chapter is an adapted version of an article submitted for publication. Authors: AL Francke, B Garssen, JB Luiken, AME de Schepper, M Grypdonck \& H Huijer Abu-Saad. 


\section{Effects of the program on patients}

\section{Summary}

The effects of the pain C.E program on patients are described. Statistical analyses revealed that the program resulted in a lower pain intensity of surgical colon and breast cancer patients. However, no effects were found on pain duration, sleepless hours as a result of pain, state anxiety, mood disturbances, and duration of hospitalization. It is assumed that pain CE programs that have a moderate impact, may affect pain intensity more easily than the other outcome variables mentioned.

\section{Introduction}

For humane as well as for medical reasons, adequate pain relief for surgical cancer patients is of great importance. Postoperative pain may reinforce mood disturbances and compromise patient outcomes, resulting in longer recovery periods (Acute Pain Management Guideline Panel, 1992; Bonica, 1987). However, pain is often insufficiently relieved in practice (e.g. Abbott et al., 1990; Carr, 1990; Oden, 1989). Paice et al. (1991), for instance, interviewed a large group of surgical cancer patients and found that $76 \%$ had mild to severe pain at the time of the interview.

One of the reasons for insufficient pain relief may be that nurses do not always assess the presence and characteristics of pain (Paice et al., 1991; Grossman et al., 1991). In addition, many nurses administer analgesics irregularly and in ineffective dosages (Carr, 1990; Closs, 1990). Furthermore, nurses often do not make optimum use of nonpharmacological interventions, like relaxation, distraction and massage (see Chapter 3; Dalton, 1989; Francke, 1992).

Of the number of studies on pain CE programs for nurses (see Chapter 2), four have examined whether patients are also affected by the CE program (Degner et al., 1982; Foglesong, 1983; Foglesong et al., 1987; Sofaer, 1984). In the Foglesong (1983) and Foglesong et al. (1987) studies it was concluded that surgical patients admitted after the program had less pain complaints. Sofaer (1984) found that surgical patients admitted after a CE program for nurses had lower pain intensity and fewer hours of pain on postoperative days 0 and 1. Degner et al. (1982) established after a CE program for nurses, that oncological patients had more pain-free periods, probably as a result of changes in nurses' pharmacological pain management.

This chapter aims to provide insight into the effects of the pain CE program (presented in Appendix D) on patients. The following research questions are addressed.

Does the CE program result in:

1. a decrease in patients' postoperative pain? More specifically formulated,
a. a decrease in the intensity of postoperative pain?
b. a decrease in pain duration during the day?
c. a decrease in the number of sleepless hours as a result of pain?

2. a decrease in patients' state anxiety and mood disturbances?

3. a decrease in patients' length of hospitalization? 


\section{Methods}

Design. Effects of the program were measured in a pretest-posttest control group design, using randomization at ward level. Data from patients in both conditions were collected in two measurement periods: 0-3 months before the program (period $\mathrm{Ml}$ ) and 3-6 months after the program (period M2). (See also the 'Design' sections in Chapters 6 and 8.)

Sample. In each of the five participating hospitals, two surgical wards were involved. Effects of the program were measured in 152 surgical cancer patients. Patients studied met the following inclusion criteria: being hospitalized for a curative resection of colon or breast cancer, having a life expectancy of more than six months, and active command of the Dutch language.

Patients who participated in the study were spread over four groups: a group admitted to the 'experimental wards' in period M1, a group admitted to the 'experimental wards' in period M2, a group admitted to the 'control wards' in period M1, and a group admitted to the 'control wards' in period M2. (See also Chapter 8 and Table 9.1.)

Program. Major program items were: a) pain and the assessment of pain, b) psychosocial interventions, c) physical and relaxation interventions, and d) pharmacological pain management. Content, educational method and other characteristics of the program are described in more detail in Chapters 4 and 6 and in Appendix I.

Instruments. Pain intensity was measured with the Numerical Rating Scale (Scott \& Huskusson, 1976). Pain duration, and the number of sleepless hours as a result of pain were determined with two relevant items of the Dutch version (Verkes et al., 1989) of the McGill Pain Questionnaire Quality of Life-scale (Melzack, 1975).

State anxiety was determined with four items of the Dutch version (Van der Ploeg et al., 1980) of the State-Trait Anxiety Inventory (Spielberger et al., 1970). Mood disturbances were assessed with the Dutch, shortened adaptation (Wald \& Mellenbergh, 1990) of the Profile of Mood States (McNair et al., 1971).

Patient files were studied to gather information on sociodemographic data and length of hospitalization. (Detailed information about these instruments and about the data collection procedures is provided in Chapter 8.)

Statistical analyses. For continuous data, differences in background characteristics were tested with ANOVA, while hierarchical loglinear analysis (LR $X^{2}$ ) was used for categorical data. The two-sided significance level was fixed at 0.05 (see Table 9.1). 
Täble 9.1. Comparison between the four groups of surgical colon cancer patients distinguished, and berween the four groups of surgical breast cancer patients distinguished, with respect to background characteristics.

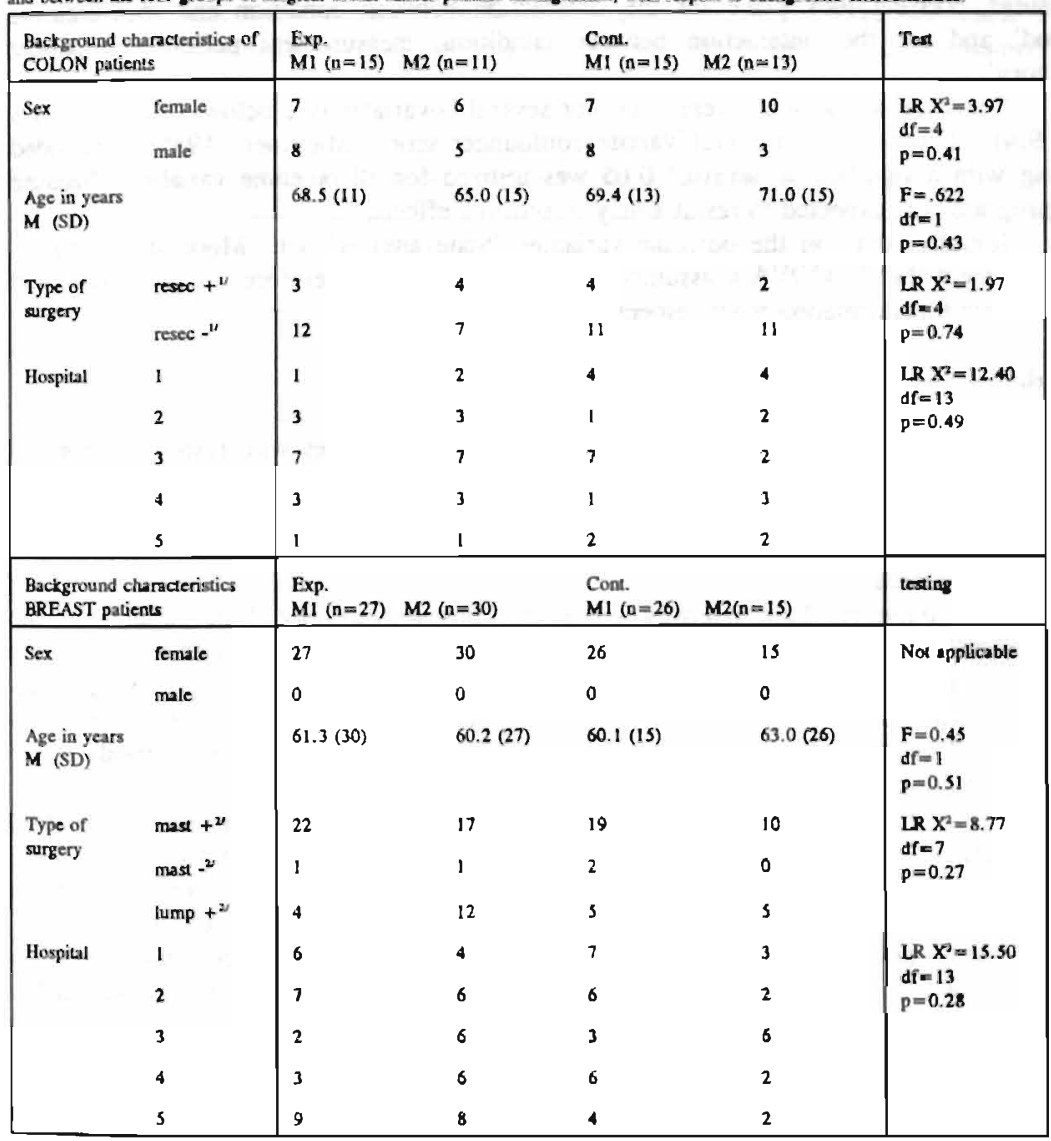

${ }^{u}$ resec $+=$ colon resection with colostomy; resec - = colon resection without colostomy.

"mast + = mastectomy with lymphe node resection; mast - = mastectomy withous lymphe node rescction, lump $+=$ lumpectomy with lymphe node resection. 
Effects on all patient outcomes were determined by ANCOVA for repeated measures. Testing took place for the 'interaction between condition and measurement period' and for the 'interaction between condition, measurement period and patient category'.

Statistical adjustments were made for several covariates (see below Tables 9.2, 9.3 and 9.4), all combined in a multivariate confounder score (Miettinen, 1985). One-sided testing with a significance level of 0.05 was utilized for all outcome variables, because the program was expected to result solely in positive effects.

Initially, data on the outcome variables 'State anxiety' and 'Mood disturbances' did not meet the ANCOVA's assumption of normality and therefore a square root and logarithmic transformation were respectively applied.

\section{Results}

Background characteristics. There were no significant differences with respect to relevant background characteristics between the four groups of colon cancer patients and between the four groups of breast cancer patients distinguished (see Table 9.1).

\section{Postoperative pain}

Pain intensity. Pain intensity scores for postsurgical day 2 of patients in the experimental condition are lower after the program than before; both in colon and breast cancer patients (see Table 9.2, and Figures 9.1 and 9.2). In other words, patients admitted after the CE program have less intense pain on day 2 than comparable patients admitted before the program. There is a trend across the two measurement periods in the reverse direction in the control condition.

There are no obvious changes across the measurement periods in colon and breast cancer patients' pain intensity for day 4 in the experimental condition (see Table 9.2). However, there is some increase in colon cancer patients' pain intensity for day 4 in the control condition. Statistical testing reveals significant interaction between condition and measurement period (see Table 9.2), indicating a difference in trend between experimental and control patients. It can therefore be concluded that the program had a positive effect on pain intensity. The interaction involving patient category was not significant, indicating beneficial effects for both colon and breast cancer patients.

Pain duration. On days 2 and 4, patients also indicated the number of hours of pain they had experienced during the previous day. Table 9.2 shows that, although scores vary over time, there is no significant difference in trend between experimental and control patients. This indicates that the program did not lead to a decrease in duration of pain. 
Sleepless hours as a result of pain. Experimental and control patients did not differ in trend with respect to the number of hours that pain kept them awake (see Table 9.2). This leads to the conclusion that the program did not significantly affect the number of sleepless hours either.

Table 9.2. Mean scores on postsurgical 'Pain intensity', 'Pain duration', and 'Sleepless hours as a result of pain' (SD's are between brackess), tested with ANCOVA for repealed measures".

\begin{tabular}{|c|c|c|c|c|c|c|c|}
\hline & Category & Day & Condition & MI & M2 & $\begin{array}{l}\text { Condition X } \\
\text { period }\end{array}$ & $\begin{array}{l}\text { Condition } x \\
\text { period } x \\
\text { patient calegory }\end{array}$ \\
\hline $\begin{array}{l}\text { Pain intensily } \\
\text { (range:0- 10) }\end{array}$ & colon & $\begin{array}{l}\text { day } 2 \\
\text { day } 4 \\
\text { day } 2 \\
\text { day } 4\end{array}$ & $\begin{array}{l}\text { exp. } \\
\text { cont. } \\
\text { exp. } \\
\text { cont. } \\
\text { exp. } \\
\text { cont. } \\
\text { exp. } \\
\text { cont }\end{array}$ & $\begin{array}{l}3.3(2.3) \\
3.3(2.4) \\
2.3(2.3) \\
2.3(1.7) \\
2.8(2.4) \\
2.6(2.7) \\
1.7(2.3) \\
1.4(1.8)\end{array}$ & $\begin{array}{l}2.9(2.7) \\
4.7(2.5) \\
2.3(2.1) \\
3.1(2.9) \\
1.8(2.1) \\
3.1(3.0) \\
1.5(2.1) \\
1.2(1.9)\end{array}$ & $\begin{array}{l}F=4.23 \\
\text { df }=1 \\
p=0.02\end{array}$ & $\begin{array}{l}F=0.00 \\
d f=1 \\
p=0.47\end{array}$ \\
\hline $\begin{array}{l}\text { Pain dursion } \\
\text { (range:Q-16) }\end{array}$ & breast & $\begin{array}{l}\text { day } 2 \\
\text { day } 4 \\
\text { day } 2 \\
\text { day } 4\end{array}$ & $\begin{array}{l}\text { exp. } \\
\text { cont. } \\
\text { exp. } \\
\text { cont. } \\
\text { exp. } \\
\text { con. } \\
\text { exp. } \\
\text { cont. }\end{array}$ & $\begin{array}{l}12.1(5.6) \\
10.6(7.1) \\
8.2(6.9) \\
12.1(7.1) \\
9.5(7.2) \\
9.0(7.0) \\
7.2(6.9) \\
4.6(5.9)\end{array}$ & $\begin{array}{l}7.0(6.4) \\
9.9(7.0) \\
10.4(6.6) \\
9.6(6.6) \\
8.1(6.7) \\
8.3(6.7) \\
6.0(6.9) \\
5.1(6.4)\end{array}$ & $\begin{array}{l}P=0.87 \\
d I=1 \\
p=0.18\end{array}$ & $\begin{array}{l}\mathrm{P}=0.03 \\
\mathrm{dr}=\mathrm{l} \\
\mathrm{p}=0.44\end{array}$ \\
\hline $\begin{array}{l}\text { Sleepless hours } \\
\text { (range: }(0-8)^{2}\end{array}$ & breast & $\begin{array}{l}\text { day } 2 \\
\text { dny } 4 \\
\text { dey } 2 \\
\text { dey } 4\end{array}$ & $\begin{array}{l}\text { exp. } \\
\text { eond. } \\
\text { exp. } \\
\text { cont. } \\
\text { exp. } \\
\text { con. } \\
\operatorname{cxp} . \\
\operatorname{con} \alpha\end{array}$ & $\begin{array}{l}0.5(1.1) \\
0.4(0.8) \\
0.5(1.1) \\
0.8(1.2) \\
0.6(1.0) \\
0.2(0.5) \\
0.2(0.6) \\
0.1(0.3)\end{array}$ & $\begin{array}{l}1.4(1.3) \\
1.0(1.3) \\
0.8(1.2) \\
0.7(1.1) \\
0.3(0.7) \\
0.7(1.0) \\
0.1(0.5) \\
0.6(0.9)\end{array}$ & $\begin{array}{l}F=1.29 \\
d f=1 \\
p=0.13\end{array}$ & $\begin{array}{l}F=2.53 \\
d f=1 \\
p=0.06\end{array}$ \\
\hline
\end{tabular}

\footnotetext{
"With satiatical adjustoent for 'Pain intentity seore for the day before sargery', 'State anxiey score for the day before surgery'.

'Hospital'. "Type of surgety". 'Age', 'Sex' and 'Number of days in intensive care".

"The most favorable scores are underined.
} 


\section{Chapter 9}

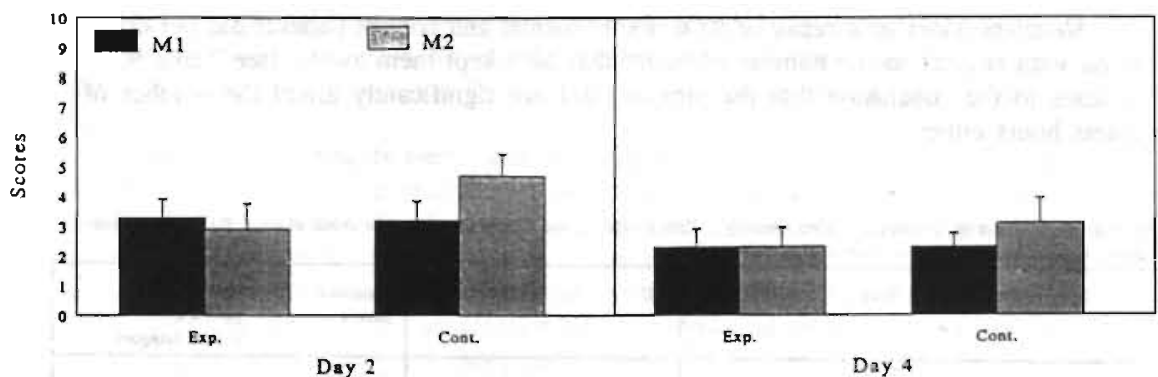

Figure 9.1. Mean pain intensity (and standard error) for postsurgical days 2 and 4 in surgical colon cancer parients.

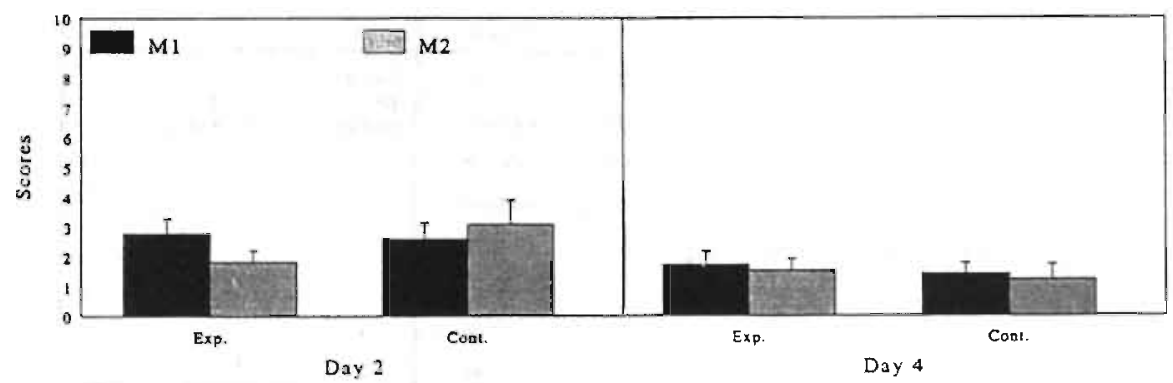

Figure 9.2. Mean pain intensity (and standard error) for postsurgical days 2 and 4 in surgical breast cancer patients.

\section{Psychological stat:}

State anxiety. Experimental colon and breast cancer patients' anxiety scores for days 2 and 4 are almost the same after the program than before (see Table 9.3) There is no significant difference in trend with patients in the control condition (see Table 9.3), indicating that the program did not result in a decrease of patients' state anxiety.

Mood disturbances. The program did not result in a decrease in mood disturbances either. This conclusion can be derived from the nonsignificant difference in trend between patients in boch conditions (see Table 9.3). 
Table. 9.3. Mean scores on state anxiety and mood fisturbances (SD's are between brackets), teated with ANCOVA for repeatod measures

\begin{tabular}{|c|c|c|c|c|c|c|c|}
\hline & $\begin{array}{l}\text { Patien } \\
\text { category }\end{array}$ & Day & $\begin{array}{l}\text { Condi- } \\
\text { tinn }\end{array}$ & MI & $\mathrm{M} 2$ & $\begin{array}{l}\text { Condition } x \\
\text { period }\end{array}$ & $\begin{array}{l}\text { Condition } \times \text { period } \times \\
\text { patient category }\end{array}$ \\
\hline $\begin{array}{l}\text { Slate anxiety } \\
\text { (range: } 2-4)^{2}\end{array}$ & $\begin{array}{l}\text { colon } \\
\text { breast }\end{array}$ & $\begin{array}{l}\text { day } 2 \\
\text { day } 4 \\
\text { day } 2 \\
\text { day } 4\end{array}$ & $\begin{array}{l}\text { exp. } \\
\text { cent. } \\
\text { exp. } \\
\text { cont. } \\
\text { exp. } \\
\text { cont. } \\
\text { exp. } \\
\text { cont. }\end{array}$ & $\begin{array}{l}2.9(0.4) \\
3.0(0.5) \\
2.9(0.5) \\
3.1(0.4) \\
3.1(0.5) \\
3.0(0.5) \\
2.9(0.5) \\
3.0(0.5)\end{array}$ & $\begin{array}{l}2.9(0.6) \\
3.2(0.4) \\
3.0(0.6) \\
3.10 .4) \\
2.9(0.4) \\
2.9(0.5) \\
2.9(0.5) \\
3.0(0.5)\end{array}$ & $\begin{array}{l}F=0.12 \\
d r=1 \\
p=0.36\end{array}$ & $\begin{array}{l}F=0.18 \\
d f=1 \\
p=0.34\end{array}$ \\
\hline $\begin{array}{l}\text { Mood disturbance } \\
(\text { range: } 0.7-4.9)^{2 / 4}\end{array}$ & $\begin{array}{l}\text { colon } \\
\text { breast }\end{array}$ & $\begin{array}{l}\text { day } 2 \\
\text { day } 4 \\
\text { day } 2 \\
\text { day } 4\end{array}$ & $\begin{array}{l}\text { exp. } \\
\text { cont. } \\
\text { exp. } \\
\text { cont. } \\
\text { exp. } \\
\text { cont. } \\
\text { exp. } \\
\text { cont. }\end{array}$ & $\begin{array}{l}3.1(0.2) \\
3.2(0.4) \\
2.9(0.4) \\
3.2(0.5) \\
3.0(0.5) \\
3.1(0.6) \\
2.9(0.6) \\
3.0(0.7)\end{array}$ & $\begin{array}{l}3.1(0.3) \\
3.1(0.1) \\
3.0(0.5) \\
3.1(0.3) \\
3.0(0.4) \\
3.0(0.5) \\
2.9(0.5) \\
2.9(0.5)\end{array}$ & $\begin{array}{l}F=1.26 \\
d f=1 \\
p=0.13\end{array}$ & $\begin{array}{l}\mathbf{F}=0.00 \\
\mathrm{dr}=1 \\
\mathrm{p}=0.48\end{array}$ \\
\hline
\end{tabular}

"With staistiesl adjustment for 'Pain interxity score for the day before suryery'. 'State anxidy score for the day before surgery",

'Hospital', 'Type of surgery'. 'Age'. 'Sex' and 'Number of days in insensive care'.

2 The mast faverable scores are underlined.

* Square root transformed scores.

- Logarithmic transformed scores.

Length of hospitalization. The length of hospitalization of colon and breast cancer patients' (computed from the day of surgery) varies considerably across the two measurement periods. There is, however, no significant difference in trend between experimental and control patients (see Table 9.4), and the program appears to have had no effect on length of hospitalization.

Table 9.4. Mean scores on length of hospitalization (SD's are between brackets), teated with ANCOVA for repeated meanures"

\begin{tabular}{|c|c|c|c|c|c|c|}
\hline & $\begin{array}{l}\text { Paliend } \\
\text { category }\end{array}$ & $\begin{array}{l}\text { Condj- } \\
\text { tion }\end{array}$ & M1 & $M 2$ & $\begin{array}{l}\text { Condition } x \\
\text { period }\end{array}$ & $\begin{array}{l}\text { Candition } x \\
\text { period } x \\
\text { patien calegory }\end{array}$ \\
\hline \multirow[t]{3}{*}{$\begin{array}{l}\text { Length of hos- } \\
\text { pitalization in } \\
\text { days }\end{array}$} & colon & $\begin{array}{l}\exp . \\
\cosh .\end{array}$ & $\begin{array}{l}13.5(7.2) \\
14.3(6.3)\end{array}$ & $\begin{array}{l}16.0(8.2) \\
14.2(6.0)\end{array}$ & $\begin{array}{l}P=1.12 \\
a r=1 \\
p=0.15\end{array}$ & $\begin{array}{l}F=0.71 \\
\text { of }=1 \\
p=0.20\end{array}$ \\
\hline & breast & exp. & $9.3(3.0)$ & $8.8(3.5)$ & & \\
\hline & & cont. & $8.3(3.4)$ & $9.4(3.5)$ & & \\
\hline
\end{tabular}

\footnotetext{
"With statistical adjustmen for 'Pain intensity scure for the day before surgery'. 'State anxiety score for the day before surgery'. 'Hospital'. "Type of argery'. 'Age'. 'Sex' and 'Numbet of days in intensive care'.
} 


\section{Chapter 9}

\section{Discussion}

The foregoing shows that the CE program had a positive effect on surgical colon and breast cancer patients' pain intensiry. However, it is not completely clear which changes in nurses' interventions are related to the decrease in patients' pain intensity. Other parts of the study revealed that the quality of nurses' psychosocial, physical and relaxation interventions (sce Chapter 7), and the quality of nurses' analgesic administrations improved (see Chapter 8). It is not very likely that effects on pain intensity are caused by quality improvements of psychosocial interventions, since there are no significant changes in state anxiety and mood disturbances. It seems more probable that quality improvements of either physical and relaxation interventions or analgesic administrations have resulted in less intense pain.

No effects were established on duration of hospitalization. In this decade every patient is discharged from the hospital as soon as possible. It may therefore be too optimistic to expect some changes on this outcome variable as a result of nurses participating in pain programs. For future studies, alternative outcome variables related to patients' recovery process have to be searched for.

Despite the assessed decrease in pain intensity, patients' pain duration, and number of sleepless hours as a result of pain did not change significantly. Probably the changes in pain intensity were too moderate to have consequences for the other outcome variables.

Previous studies on the impact of pain CE programs on patients (Degner et al., 1982; Foglesong, 1983; Foglesong et al., 1987; Sofaer, 1984) did not determine the number of sleepless hours as a result of pain, state anxiety, mood disturbances or duration of hospitalization, impeding comparisons with the study presented. Sofaer (1984) did, however, determine patients' pain intensity and duration. As in our study, Sofaer found no significant decrease in pain duration on day 2. Contrary to our findings, Sofaer's did not indicate a significant decrease in pain intensity for day 2 . Sofaer did, however, assess a significant decrease in pain intensity scores for the postoperative days 0 and 1 . It is not known if our program had an equally positive effect on pain intensity scores for the first two postoperative days. No data were obtained from patients during these days to avoid extra burden immediately after surgery. Retrospective questions did not seem to be a useful alternative since patients in our sample found it difficult to remember the precise pain intensity for the immediate postoperative period.

Comparisons between our findings and those of other authors are also impeded by methodological differences. In contrast to our study, other pain CE studies which measured patient outcomes (Degner et al., 1982; Foglesong, 1983: Foglesong et al., 1987; Sofaer, 1984), did not include a control condition. However, limited insight is provided into the extent to which changes can be attributed to a CE program without a control condition. Illustrative is that if no control condition had been involved in the study presented, the changes in pain duration (see Table 9.2) would have been incorrectly related to the program. Furthermore, none of the aforementioned $\mathrm{CE}$ studies involving measurements among patients used statistical adjustment for confounding variables. The study presented illustrates that this procedure is valuable in promoting the internal validity of results. For example, the average scores in Table 9.4 show a considerable. unexpected 
increase in the duration of hospitalization of experimental patients undergoing colon surgery. The difference in trend proved to be insignificant when statistical adjustments were made for the type of surgery and other relevant variables. It is recommended that future studies also use control group designs and statistical adjustment for confounding variables. More insight into the effects of pain CE programs on patient outcomes may then be gained.

Finally, a short comment on noncooperation of patients and how this may have affected the reliability of the data. As stated, patients were indirectly recruited through nurses. Nurses did not systematically inform us about patients who did not want to cooperate. However, nurses did suggest that the percentage of noncooperation was very low (probably less than $10 \%$ ). This indicates that the results are to a large extent representative for the population of surgical colon and breast cancer patients admitted to the five hospitals involved. However, because patients experiencing a high level of physical or psychological discomfort probably refused more often than patients with less discomfort there may be limited bias.

\section{References}

Abbott FV, Gray-Donald K. Sewitch MJ, Johnston CC. Edgar L \& Jeans ME (1990). The prevalence of pain in hospitalized patients and resolution over six months. Pain, 50, 15-28.

Acute Pain Management Guideline Panel (1992). Acute pain manogement: operarive or medical procedures and trauma. Clinical practice guideline. AHCPR Pub.: No.92-0032. Rockville MD: Agency for Health Care Policy and Research. Public Health Service, US Department of Health and Human Services.

Bonica JJ (1987). Lmportance of effective pain control. Acta Anaesthesiologica Scandinavica 31. 1-16.

Carr ECJ (1990). Post-operative pain: patients' expectations and experiences. Joumal of Advencet Nursing 15. $89-100$,

Closs S3 (1990). An exploratory analysis of nurses' provision of postoperative aralgesic drugs. Joumal of Advanced Nursing 15, 42-49.

Dalton JA (1989). Nurses' perceptions of their pain assessment skills, pain management practices, and attindes toward pain. Oncology Nursing Forum 16, 2, 225-231.

Degner L. Fujii S \& Levitt M (1982). Implementing a program to control chronic pain of malignant disease in an extended care facility. Cancer Nursing S, 263-268.

Foglesong DH (1983). The impact of a staff development offering on nursing practice. Joumal of Continuing Education in Nursing 14, 6, 12-15.

Foglesong DH, Lambert J \& Emerick J (1987). Variables which influence the effect of staff development on nursing practice. Joumal of Continuing Education in Nursing 18, 5, 168-171.

Francke AL (1992). Wat doen verpleegkundigen bij pijn? Tijdschrîf woor Zickenwerpleging 102, 13,460463.

Grossman SA, Scheidler VR. Swedeen K. Mucenski J \& Piantadosi S (1991). Correlation of patient and caregiver tatings of catcer pain. Joumal of Pain Symptom Munagement 6. 2, 53-57.

McNair DM, Lorr M \& Droppleman LF (1971). Edirs Manual for the Prefile of Mood Siates. San Diego. Califormia: Educational and Industrial Testing Service.

Melzack R (1975). The McGill pain questionnaire: major properties and scoring methods. Pain, 1, 277-299.

Mietliuen OS (1985). Theoretical epidemiology; principles of occurrence research in medicine. New York: Wiley.

Oden RV (1989). Acute post-operative pain. Incidence. severity, and the etiology of inadequate treatmen. Anesthesiology Clinics of North America 7, 1, 1-15.

Paice JA, Mahon SM \& Faut-Callahas M (1991). Factors associated with adequate pain control 
inhospitalized postsurgical patients diagnosed with cancer. Cancer Nursing 14, 6, 298-305.

Ploeg HM van der, Defares PB \& Spielberger CD (1980). Handleiding bij de Zelf-Beoordelings Vragenlijst. Een nederlandstalige bewerking wan de Spielberger State-Trait Anxiety Inventory. Lisse: Swets \& Zeidinger B.V.

Scott J \& Huskisson EC (1976). Graphic representation of pain. Pain. 2, 175-184.

Sofaer B (1984). The effect of focused education for nursing teams on postoperative pain of patients. Dissertation. Edinburgh: University of Edinburgh.

Spielberger CD, Gorsuch RL \& Lushene RE (1970). Manual for the State-Trait Anxiety Inventory. Palo Alto, California: Consulting Psychologists Press.

Verkes RJ, Vanderiet K, Vertommen H, Van der Kloot WA \& Van der Mey J (1989). De MPQ-DLV: een standaard Nederiandstalige versie van de McGill Pain Questionnaire voor Belgie̋ en Nederland, 1989. In WA van der Kloot \& $\mathrm{H}$ Vertommen (Eds.). De MPQ-DLV. Een standaard nederlandstalige versie van de McGill Pain Questionnaire (pp. 57-69). Lisse: Swets \& Zeitlinger.

Wald FDM \& Mellenbergh GJ (1990). De verkorte versie van de Nederlandse vertaling van de Profile of Mood States (POMS). Nederlands Tijdschrift voor Psychologie, 45, 86-90. 


\section{CHAPTER 10 Nurses' perceptions of factors influencing the use of the program in nursing practice}

This chapter is an adapted version of an article submitted for publication. Authors: AL Francke, ABT Lemmens, H Huijer Abu-Saad \& M Grypdonck. 


\section{Nurses' perceptions of factors influencing the use of the program in nursing practice}

\section{Summary}

Factors which, according to participants, influenced the application of what was learned in the pain CE program were explored by means of qualitative interviews. Participants indicated that the correspondence between the program and their personal view on pain management, attitudes towards the program and innovations in general, self-efficacy perceptions, and (un)familiarity and taboos with respect to program items had influenced what they put into practice. In addition, participants indicated that interactions with colleagues, nursing managers, patients and physicians affected their application of the program. Furthermore, organizational factors, such as limited time and lack of formal program implementation, were mentioned as influential.

\section{Introduction}

The Chapters 6-9 of this dissertation describe how the effects of the pain CE program were measured in a controlled intervention study. Such quantitative studies yield relevant information on the effects of programs. However, researchers, program instructors and policy makers are often also interested in factors influencing program outcomes. When insight into these factors is gained, it will be possible to improve the program and its social and organizational conditions (Verschuren, 1994).

Several indications of what factors may affect the impact of educational programs are given in CE literature (e.g. Cervero, 1985; Cervero et al., 1986; Waddell, 1992; Wake, 1987;), as well as in social psychological publications (e.g. Ajzen \& Fishbein, 1980; Ajzen, 1988; Bandura, 1986). The literature suggests that the impact of CE programs is determined by characteristics of the participant, the program itself, the program instructors, the participants' social system, and the human relationships and physical environment during the program (for a more thorough description of these factors and their interrelations, see Francke et al., 1995). However, previous publications often focus on factors influencing the use of programs or innovations not directly related to pain aspects. Yet factors which affect the application of one program are not necessarily important within the framework of other programs in other settings. Therefore, besides the quantitative measurements described in the foregoing chapters, evaluation interviews with participants of the pain CE program were conducted. The aim of these interviews was to explore factors influencing the use of the pain CE program. We chose to explore influencing factors from a participant's perspective since this increases the chance of conclusions and recommendations useful in nursing practice (Verschuren, 1994). The interviews were qualitative in nature, since qualitative research methods are most appropriate for describing individual perceptions and experiences (see Chapter 3; Chenitz \& Swanson, 1986; Strauss \& Corbin, 1990). The following research question was addressed in the interviews.

According to nurse participants, what factors affected the application of what had been learned in the pain CE program positively or negatively? 


\section{Methods}

Sample. A total of twelve nurses who had participated in the program were interviewed (two or three per hospital). Sociodemographic data on these interviewees are given in Table 10.1.

Interviewees were recruited by head nurses. Sample variation was achieved by instructing head nurses to recruit at least one participant who -according to the head nurse's perception- applied a great deal of the program, and at least one who applied little or nothing. This selection criterion proved useful for gaining insight into stimulating/facilitating factors, as well as inhibiting ones.

Tabic 10.1. Sociodemographic dau of participents interviewed

\begin{tabular}{|c|c|c|}
\hline \multicolumn{2}{|c|}{ Sociodemographic data } & \multirow{2}{*}{$\begin{array}{l}\text { Number } \\
11\end{array}$} \\
\hline Sex & female & \\
\hline & malc & 1 \\
\hline \multirow[t]{3}{*}{ Age (years) } & $21-30$ & 9 \\
\hline & $31-40$ & 2 \\
\hline & $41-50$ & I \\
\hline \multirow[t]{2}{*}{ Ceucasian } & yes & 12 \\
\hline & no & 0 \\
\hline \multirow[t]{3}{*}{ Years qualified } & $0-5$ & 9 \\
\hline & $6-10$ & 1 \\
\hline & $>10$ & 2 \\
\hline \multirow[t]{5}{*}{ Working in: } & haspital I & 2 \\
\hline & hospilat II & 2 \\
\hline & hospital III & 2 \\
\hline & turspilal IV & 3 \\
\hline & hospital V & 3 \\
\hline
\end{tabular}

Program. Major program items were: a) pain and the assessment of pain, b) psychosocial interventions, c) physical and relaxation interventions and d) pharmacological pain management. Content, educational method and other characteristics of the program are described in more detail in Chapters 4 and 6 and in Appendix I.

Data collection. Participants were interviewed by the researcher or a co-researcher. All interviews were conducted six to twelve months after the end of the program ${ }^{33}$. They took place in a separate room on the ward and lasted about forty-five minutes. The

w. Infomed consent was obtained prior to each interview and anonyuity and confidentiality were guaranteed. 
interviews were semi-structured by an interview schedule. The initial questions on the schedule were: "Do you make use of what you have learned in the CE program?" and "What factors influenced the use of what you have learned?". Subsequent questions were more specific and to a large extent based on 'sensitizing concepts' derived from the literature (e.g. 'openness to innovations', 'support from colleagues' and 'support from superiors', see Francke et al., 1995). The term 'sensitizing concepts' refers to open concepts, which guide the initial phases of data collection and analysis (Wester, 1991). As is usual in qualitative research, these concepts were only used as a conceptual framework, not as a definitive one.

Data collection was stopped after twelve interviews; no new relevant data seemed to emerge during the last interviews, which indicated that a saturation point (Strauss \& Corbin, 1990) had been reached.

Qualitative analysis. A common characteristic of qualitative approaches is the cyclic process of data collection, analysis and interpretation (e.g. Miles \& Huberman, 1984; Strauss \& Corbin, 1990). In connection with this process, literal transcription and analysis took place immediately after each interview. The transcribed material was read through several times, and relevant fragments were assigned one or more code words (Miles \& Huberman, 1984; Strauss \& Corbin, 1990). All the cade words were based directly on the content of the fragments and/or on sensitizing concepts. Subsequently, the interview material was arranged; fragments with similar code words were put together. Answers to the research questions were explored by carefully analyzing the arranged interview material (see Chapter 3).

Triangulation of researchers (Lincoln \& Guba, 1985) was used to increase the quality of the analyses: the researcher and co-researcher first analyzed an interview independently and then discussed codes and interpretations. Peer debriefing (Lincoln \& Guba, 1985) was another method for improving quality: interim analyses were discussed in a working group of qualitative nursing researchers. In addition, feedback from interviewees was received (Lincoln \& Guba, 1985; Miles \& Huberman, 1984; Wester, 1991): interim reports were presented, after which interviewees indicated whether they agreed with the analyses. Furthermore, an external researcher analyzed part of the 'rough' interview material. Her analyses were compared with those of the researcher and co-researcher. Mutual analyses were found to be parallel to a large extent. However, when interpretations did not parallel they were discussed, giving rise to further development and adjustment of codes and sensitizing concepts. These analytic activities ultimately resulted in the construction of Model 10.1. 


\section{Results}

Model 10.1 displays the factors that, according to participants, influenced application of what was learned in the program. These factors will be discussed in this section.

Model 10.1. Factors that influence the application of the pain CE program

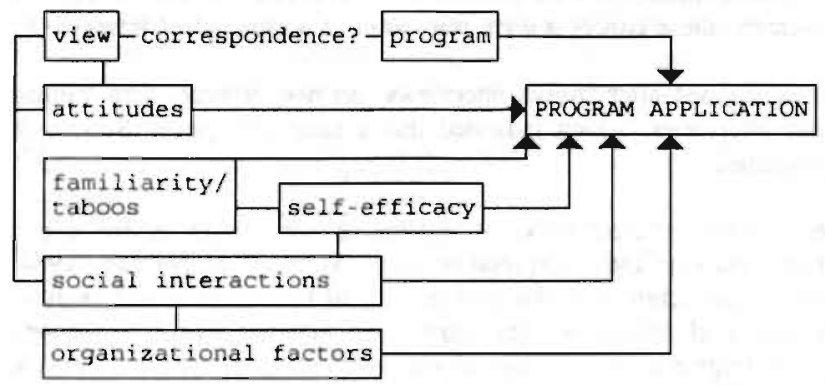

Correspondence benveen view on pain management and program. Two types of views on pain management can be distinguished among the group of interviewees: an 'integrated' and a 'pharmacological' view. Interviewees with an integrated point of view thought that in addition to pharmacological interventions- psychosocial and other nonpharmacological interventions were essential for providing adequate pain relief.

In contrast, interviewees with a definite pharmacological view saw nursing pain management as almost synonymous to the provision of analgesics. They described themselves as practical, down-to-earth people who were more oriented to cure than to care.

"A certain level-headedness, which I myself clearly experienced as well. When I'm on night duty and there is a patient who is in great pain, I automatically give an injection. It is really not that I do not have enough time at night to have a talk with the patient, but it's a surgical nurse's mentality". (int.4 from hosp.II: pharmacological view $)^{4}$

These participants thought that, with respect to pain management, psychosocial interventions were of minor importance. Other nonpharmacological interventions such as massage, distraction or relaxation, they considered as not belonging to nurses' professional domain.

Interviewees with an integrated view indicated that the program content fitted very well with their personal view on pain management, and consequently they felt encouraged and inspired by the program. These participants also expressed that they were fond of the two program instructors and of the instructors' didactic strategies. They considered the instructors capable, committed and enthusiastic, and they appreciated it that the instructors

$1 /$ 'Int. 4 from hosp. II means interviewee number 4 coming fron hospital II. 
gave a lot of examples from nursing practice. The latter made it easier for them to bridge the gap from the program to the daily work. Furthermore, these participants enjoyed the practical exercises which they saw as an opportunity to get acquainted with relatively new interventions, such as massage, relaxation and distraction. Inasmuch as they had experienced the beneficial effects of these interventions themselves, they now applied them after the program -though not always very frequently- in practice.

Interviewees with a pharmacological view, however, indicated that their personal view on pain management had not linked up with nonpharmacological parts of the program. As a result, they hardly applied, if at all, what they had been taught. These interviewees also said that they did not appreciate the practical exercises. They would rather have spent more time on the extension of theoretical, pharmacological knowledge, which would have been of more use to them in actual practice.

\section{Attitudes}

Attitude towards the program. Social psychology and health education publications emphasize that a person's attitudes towards a certain topic highly determine actual behavior (e.g. Ajzen \& Fishbein, 1980; Ajzen, 1988; Bandura, 1986; De Vries \& Backbier, 1995). Participants' remarks pointed along the same lines. Interviewees with an integrated view indicated they had positive attitudes towards the program. They liked to learn more about new approaches to pain relief and share their experiences with close colleagues. According to these interviewees, their positive attitude had beneficial consequences for the application of the program in nursing practice.

However, interviewees with the pharmacological viewpoint reported a negative attitude towards the program. They even felt some aversion for the program beforehand, which was related to their scepticism towards issues such as massage and relaxation techniques, and to the fact that they felt more or less compelled to participate. In theory they had a choice of whether or not to participate. Still, if they did not cooperate they would have come into undesirable discussions with superiors. Their negative attitude towards the program became even more negative when nursing managers were initially not explicit about compensation of free hours and replacement of personnel during the program (see section 'Social interactions'). This reinforced negative attitudes towards the program, which also had negative consequences on the application of what was learned.

Attitude towards innovations in general. Interviewees with a pharmacological view indicated that their negative attitude towards the program was related to a general lack of openness to innovations (see Rogers \& Shoemaker, 1971). This was particularly the case with respect to nonpharmacological, innovative programs, which these participants approached sceptically and suspiciously.

Most interviewees with an integrated view indicated an openness to innovative programs. Yet, even among these interviewees there were some who pointed out that they were not very innovative because they were set in their routines. This impeded such things as a structural use of pain rating scales. Only when they considered a new approach very important, did they think it worth the time and trouble.

"So, we are a bit lazy. That is basically what it boils down to. It is a matter of mentality". (int. 10 from hosp.V; integrated view) 


\section{Chapter 10}

Self-efficacy. Bandura (1986) indicates that self-efficacy perceptions, conceptualized as people's judgements of their capacity to organize and execute actions, are determinants of behavioral change. The influence of self-efficacy also emerges from the interviews. For instance, interviewees with an integrated view considered their knowledge of and skills regarding psychosocial interventions adequate. According to them this was one of the reasons why they frequently used the psychosocial interventions dealt with in the program.

However, these participants also indicated that their self-efficacy with respect to certain nonpharmacological interventions was low. They, for instance, thought the time spent in the program on massage was too brief for them to be able to put this intervention into practice.

"We talked about it during the program, but massage is not just a little rubbing, of

course. You really have to know what you are doing. After all, you have to

practice a lot before you can use it on a patient". (int. 9 from hosp. IV; integrated view)

Low self-efficacy with respect to nonpharmacological interventions was a problem particularly for the participants with an integrated view. For interviewees with a pharmacological view this was not a reason for not applying nonpharmacological intervention, since they did not really see the benefits of such interventions at all.

The fact that interviewees considered their self-efficacy rather high in some respects, while low on others, was not just a matter of skills, but also of how easily items could be utilized in busy daily practice. This is illustrated by the fact that interviewees with an integrated view believed that psychosocial interventions could be integrated relatively easily into their daily work. For instance, they found that washing a patient was a good opportunity to begin a conversation about the patient's pain or other problems. As for interventions such as massage or relaxation exercises, however, these interviewees felt that their possibilities were limited by a lack of time. According to them, you really had to make special time for these kinds of interventions (see 'Organizational factors').

Familiarity and taboos. Participants were more or less acquainted with certain program items as a result of earlier experiences in education or practice. In particular participants with an integrated view were familiar with psychosocial interventions, such as giving patients information and support. This familiarity influenced participants' self-efficacy perceptions, and therefore also the application of the psychosocial interventions dealt with in the program.

Conversely, unfamiliarity with program topics was considered to be an impeding factor. Interviewees felt the least familiar with massaging patients for physical and mental relaxation.

"We never talked about, or even thought of massage before. I think it is something deep-rooted, and, I have to admit that this impeding factor is indeed something I feel inside". (int.12 fron hosp. $V$; integrated view)

Unfamiliarity caused interviewees to be afraid they would feel somewhat uncomfortable and uneasy when massaging a patient. Moreover, these participants were aware that there is a certain taboo on physical contact in Western society. This taboo inhibited most of the interviewees' practising massage outside the context of decubitus prevention or painful neck or shoulders, especially in caring for members of the opposite sex. 
"Imagine that you are going to give a massage to a man. Well, that's a problem. I have trouble even talking about it. (....) It would be easier for me to massage a woman. Maybe that's strange, but then you know exactly where you stand". (int.10 from hosp.V; integrated view)

\section{Social interactions}

Interactions with colleagues. A large number of studies have established that nurses who experience support from colleagues are stimulated to use items taught in CE programs (Brasler, 1993; Brown et al., 1987; Cervero, 1985; Kiener \& Hentschel, 1989; Nolan et al., 1995; Suitor Scheller, 1993; Waddell, 1992; Wake, 1987; Warmuth, 1987). In hospitals IV and V interviewees' close colleagues (and fellow participants) had been quite satisfied and enthusiastic about the program. This was because they all -though some a little more clearly than others- had an integrated view on pain management. Because of their combined enthusiasm and the strong ties between them during the program, participants felt encouraged by one another to put the program into practice.

The situation was different for the teams from hospitals I and II, and to a lesser extent for the team from hospital III. Many of the team members had a pharmacological view on pain management and felt that the program did not correspond with what they believed important about pain management. As a result these participants confirmed one another's negative artitude towards nonpharmacological program items and their use in practice.

"I think we were all more or less on the same wavelength and none of us was really able to deal very well with nonpharmacological techniques. These exercises seemed odd to me, and when you notice that other people feel the same way too, you support one another". (int. 4 from hosp.II; phannacological view)

Interactions with colleagues affected the application of what was learned also after the program. Interviewees from hospitals IV and $\mathrm{V}$ all emphasized the positive effects of their interactions with colleagues. When, for instance, a nurse reported that she had applied a certain new technique and that it worked fine, other participants considered this a stimulus to try it themselves. Again, most interviewees from hospitals I, II and III emphasized the other side of the coin. When they heard colleagues talking negatively about program items, it discouraged them from trying these items.

Interactions with patients. Patient-nurse interactions also determined what nurses used from the program. For example, interviewees reported that younger patients were generally more open to new approaches to pain relief, and also more used to talking about pain than older patients. This fact in combination with the fact that most of the patients were middle-aged or older, impeded the use of pain rating scales and new nonpharmacological techniques.

"Old people often say: "Forget about it. Just give me a pill. Young people often

find alternative measures interesting and express this interest. However, on our ward the average age is over sixty". (int. 9 from hosp.IV; integrated view)

However, some interviewees indicated that there was a strong relationship between their own attitude and patients' reactions. When, for instance, they themselves felt unaccustomed to pain rating scales, or had a negative attitude towards them, patients reacted accordingly. 
Interactions with nursing managers. In hospitals IV and $\mathrm{V}$, the division managers or coordinating head nurses made it clear, already before the start of the program, that replacement of personnel would be arranged: partial replacement in hospital IV and complete replacement in hospital V. At an early stage, interviewees were also informed that individual compensation for hours spent on the program (outside regular working hours) would be arranged. Because of this, participants felt that their superiors did their best to make the CE program a success. This positively affected their attitude towards the program and, ultimately, its practical application.

However, interviewees in hospitals I, II and III were not satisfied with the nursing managers' information and procedures concerning compensation for hours and personnel replacement. The perception that nursing managers had not created optimal program conditions negatively affected both participants' attitude towards participation in, and use of, items covered in the program.

Interactions with physicians. The interviewees of hospitals I and III reported that the medical specialists temporarily showed some interest in patients' pain intensity scores. This stimulated participants to use the pain rating scale dealt with in the program. Soon, however, the physicians ceased showing interest, and the daily structural pain ratings were stopped.

The physicians' pharmacological policies also influenced the participants' application of the learned material. An interviewee from hospital II reported that physicians often prescribed too small doses of pain medication. Therefore, she was not able to make optimal use of the knowledge obtained during the program about the importance of regular and frequent administration of well-dosed analgesics. In contrast, the interviewees from hospital $V$ were satisfied with the medical pain policy. In their hospital, patients who had undergone extensive surgery were usually treated with epidural analgesics. These patients were therefore practically free from pain, which impeded the application of learned physical and relaxation interventions.

\section{Organizational factors}

Time. In the literature, limited time is often mentioned as a factor inhibiting the application of CE programs (Donovan, et al. 1981; Kiener \& Hentschel, 1989). For instance. Suitor Scheller (1993), described that when there is insufficient time nurses fall back on habits that do not include thoughtful use of CE knowledge. This agrees with the experiences of interviewees in this study. As for interventions such as the use of massage or relaxation exercises, however, both interviewees with an integrated and pharmacological view felt that their possibilities were limited because of lack of time.

"I simply think we are often just very busy here, and you want to see results as soon as possible. Then you don't think about things like relaxation exercises; you don't have time for that at all". (in. 2 from hosp.l; pharmacological view)

Extra personnel during the program. There was sufficient extra personnel during the program period at hospital V. In the other hospitals, substitution of personnel occurred less frequently or not at all, which meant that the nurses at these hospitals were even busier than usual during the program period and the period immediately afterwards. This negatively affected nurses' attitude and concentration during the program, which in turn negatively affected the application of new interventions afterwards. 
"You had to work three or four times as hard. Then you still had to attend the program. It was extremely tiring. You were exhausted sitting there and you just started to space out. (...) When you could concentrate better, you could retain a lot more ${ }^{n}$. (Int. 6 from hosp.lII; integraled view)

Qualified personnel in relation to nursing system. Patient allocation was pursued in all of the five teams involved. However, in reality nurses often reverted to task-oriented nursing due to a limited number of qualified nurses. As a result, student nurses carried out most direct patient care activities, whereas qualified nurses mainly engaged in doctors' rounds, administrative work and intravenous medications. Several interviewees stated that they sometimes had hardly any direct contact with patients. This was felt to be a real problem, particularly with respect to the use of the nonpharmacological interventions learned.

Formal program implementation. The program content had not been formally implemented at any of the wards involved. Since what was learned had not been translated into protocols or care plans, approaches such as the use of rating scales were not systematically employed and were not consolidated.

"You could definitely decide to implement things as a team. And if everyone sticks to the agreements, it works. But that is not the way it happened. So then you simply forget it". (int. 10 from hosp.V; integrated view)

Personnel changes. Formal implementation was considered mainly the responsibility of coordinating head nurses, division managers or other executive ward nurses. However, shortly after the program, the head nurses of the teams from hospital III, IV and V resigned. In addition to that, one of the team leaders in hospital $\mathbf{V}$ dropped out owing to protracted illness. These difficult personnel circumstances contributed to the fact that the program had not been translated into ward policy.

"A. is team leader here. He had a breakdown during that time. Then I took over his duties. J. was the other team leader, but she was quite new on the ward. So we were in a quite turbulent period (...). This all played a role". (Int.11 from hosp.V; integrated view)

Other innovative programs. Interviewees also related the lack of formal implementation to the fact that many other innovations took place which also asked a lot of nurses. In hospital V, for example, the structure of the nursing records had been changed. This mandatory innovation required considerable effort by the nurses, and as a result the practical application of the program had been pushed slighty into the background.

Character of the ward. Particularly nurses with a pharmacological view stated that their ward was characterized by many short admissions and transfers of patients from other wards. Therefore, it was difficult for them to build up relationships with patients. According to these interviewees, this inhibited the learned psychosocial interventions.

"You need, of course, some background information on patients. It is therefore necessary to know them longer. But here on this ward that is often a problem. You frequently get patients from another ward, directly after surgery. They are often anxious, in pain and insecure. But you can't attend to these patients properly, since you often know nothing about them". (int. 4 from hosp.II; pharmacological view)

However, some interviewees with an integrated view felt differently. They thought a 
nurse could still mean something to a patient, even if the patient's hospitalization was of short duration.

\section{Discussion}

Participants indicated that the extent to which their personal view on pain management corresponded with the CE program affected their use of the program. This is in line with sociopsychological publications (e.g. Ajzen, 1988; Bandura, 1986; Rogers \& Shoemaker, 1971) which also pointed to an influence of the 'fit' between innovative programs and participants' viewpoints. Participants' view on pain management may be influenced by previous learning experiences in initial nursing education. Nurse educators must be aware of their responsibilities in this respect. Their words, attitudes and behavior can influence the formation of student nurses' personal views on pain management, and, consequently, the impact of later educational experiences.

Social interactions with significant others in the work environment were indicated as another factor influencing program application. As already mentioned, the impact of social interactions on the application of CE programs is also described in many other CE studies (e.g. Brasler, 1993; Brown et al., 1987; Cervero, 1985; Kiener \& Hentschel, 1989; Nolan et al., 1995; Suitor Scheller, 1993; Waddell, 1992; Wake, 1987; Warmuth, 1987). This broad empirical support indicates that this factor definitely influences the degree to which nurses put new knowledge and skills into practice.

Participants also pointed to the influence of several organizational factors. For instance, participants were more inclined to use the CE program when managers created good program conditions than when managers were less attentive. Nursing managers therefore have to create the necessary organizational conditions for making the program a success. Adequate arrangements during the program for compensation of hours and staff replacement seem to be prerequisites in this respect. A lack of formal program implementation initiated by nursing managers was indicated as another influential organizational factor. Menzies (1960) and Lima Basto (1994) also described that in the hospital, tasks are frequently forced upwards in the hierarchy. Although ward nurses may not pass all responsibilities to others, nursing managers are indeed the most appropriate persons for translating CE programs into ward policy. In this regard, it may be effective to let division managers or coordinating head nurses participate in the CE program as well.

Several other factors were stated by participants as determinants for program application (see Model 10.1): participants' attitudes towards the program and innovations in general, self-efficacy, and familiarity and taboos. Particularly the influence of attitudes and self-efficacy perceptions received much attention in social psychology and health education (e.g. Bandura, 1986; Dijkstra et al., 1995; De Vries \& Backbier, 1995). In contrast, little is written about the possible influence of these factors in nursing $\mathrm{CE}$ literature. The interviews presented may therefore supplement previous nursing $C E$ studies. However. whether factors mentioned by nurse participants are real reasons for (non)application of what has been learned is not completely clear. A limitation of the interviews is that they only shed light on factors perceived and indicated by participants. Future research using complementary methods (e.g. observations), or additional data 
sources (e.g. nurse supervisors), may provide more insight into which tactors affect the practical application of pain CE programs.

Several additional recommendations can be made on the basis of the findings presented. To avoid severe overlaps, recommendations will be further discussed in the General Discussion of this dissertation.

\section{References}

Ajzen 1 \& Fishbein M (1980). Understanding attitudes and predicting social behavior. Englewood Cliffs NJ: Prentice Hall.

Ajzen I (1988). Attitudes, personality, and behaviour. Milton Keynes: Open University Press.

Bandura A (1986). Social foundations of thought and action. Englewood Cliffs NJ: Prentice Hall.

Brasler ME (1993). Predictors of clinical performance of new graduate nurses participating in preceptor orientation programs. Joumal of Continuing Education in Nursing 24, 4, 158-165.

Brown MC \& Brown JD \& Bayer MM (1987). Changing nursing practice through continuing education in physical assessment: perceived barriers to iniplementation. Joumal of Continuing Education in Nursing 18, 4, 1]1-115.

Cervero RM (1985). Continuing professional education and behavioral change: A model for research and evaluation. Joumal of Continuing Education in Nursing 163 85-88.

Cervero RM, Rottet S \& Dimmock KH (1986). Analyzing the effectiveness of continuing professional education at the workplace. Adult Education Quarterly 36, 2. 78-85.

Chenitz WC \& Swanson JM (1986). From practice to grounded theory. Qualitative research in nursing. California: Addison-Wesley Publishing Company.

Dijkstra A, De Vries H \& Bakker M (1995). Voor- en nadelen, eigen effectiviteit en fasen van verandering bij scoppen met roken. Gedrag en Gezondheid 23, 5, 217-228.

Donovan M, Wolpert P \& Yasko J (1981). Gaps and contracts. Nursing Outlook 29, 467-471.

Francke AL. Garssen B \& Huijer Abu-Saad H (1995). Determinants of changes in nurses' behaviour after continuing education: a literature review. Joumal of Advanced Nursing 21, 371-377.

Kiener ME \& Hentschel D (1992). What happens to learning when the workshop is over? Joumal of Continuing Education in Nursing 23, 4, 169-173.

Lincoln YS \& Guba EG (1985). Naturalistic Inquiry. Newbury Park: Sage Publications.

Linia Basto M (1994). Implementing change in nurses professional behaviours. Phd-Thesis. Lisboa:

University of Lisboa.

Menzies 1 (1960). The functioning of social systems as a defense against anxiety. Human Relations 13, 95. 121.

Miles MB \& Huberman AM (1984). Qualitative data anatysis. A sourceboak of new methads. Beverly Hills London New Delhi: Sage Publications.

Nolan M, Owens RG \& Nolan, J (1995). Continuing professional education: identifying the characteristics of an effective system. Journal of Adranced Nursing 21, 551-560.

Rogers EM \& Shoemaker FF (1971). Communication of innowations. New York: The Free Press.

Strauss AL \& Corbin J (1990). Busics of qualitarive research. Grounded theory procedures and techniques. Newbury Park, London, New Delhi: Sage Publications.

Suitor Scheller MK (1993). A qualitative analysis of factors in the ward environnent that influence nurses' use of knowledge gained from CE programs. Journal of Continuing Education in Nursing 24, 3. 114-122.

Verschuren P (1994). Toegepast evaluatie-onderzoek. Mogelijkheden en kansen voor een kwalicatieve benadering. In AL Francke \& R Richardson (Eds.). Evaluatie-onderzoek. Kansen voor een kwalitatieve benadering (pp.12-33). Bussum: Coutinho.

Vries H \& Backbier EHF (1995). Verklaring en verandering van gedrag: een beschouwing van het transtheoretische model. Tijdschrift voor Gezondheidsbewordering 16, 26-34.

Waddell DL (1992). The effects of continuing education on nursing practice: a meta-analysis. Joumal of 
Chapter 10

Continuing Education in Nursing 23, 4, 164-168.

Wake M (1987). Effective instruction in continuing nursing education. Journal of Continuing Education in Nursing 18, 6. 188-192.

Warmuth JF (1987). In search of the impact of continuing education. Joumal of Continuing Education in Nursing 18, 1, 4-7.

Wester F (1991). Strategieën voor kwalitatief onderzoek. Muiderberg: Coutinho. 


\section{General Discussion}

\section{Summary}

This final chapter is divided into three sections. The first section discusses research findings. The main conclusion is that the pain $C E$ program had a positive impact on both nurses and patients. This positive impact was, however, rather limited, which is partially explained by some participants' strictly pharmacological view on pain management. Section two discusses the benefits and limitations of the research methods used in the different parts of the project. The final section focuses on the consequences of the findings for future research, nursing practice, and education.

\section{Results: overview and reflections}

Nurses' ce needs. The first part of the research project consisted of a needs assessment study (Chapter 3 ) addressing the following research question:

What are nurses' CE needs with respect to pain assessment and management in surgical cancer patients?

Participant observations and interviews indicated CE needs in the following areas:

1) the assessment of pain. It was established that pain was usually assessed in an unsystematic and superficial way. Most nurses did not question extensively about pain, which reinforced patients' inhibition in expressing pain;

2) psychosocial interventions. Several needs regarding psychosocial interventions were described. Nurses indicated that they often did not know what to say or do when patients were in severe pain, and that they often felt powerless. Some nurses also spoke of their difficulty in achieving the right balance between involvement with, and distance from, patients with pain;

3) physical and relaxation interventions. Interventions such as massage, relaxation and distraction, were not optimally used. Some of the nurses seemed to be unaware of the potential effectiveness of these interventions;

4) pharmacological pain management. Lacks in pharmacological pain management were established as well. Insufficient pain relief appeared to be related to nurses' passive attitude towards physicians, and to nurses' and patients' misconceptions regarding sideeffects of analgesics.

Findings from the needs assessment were compared with existent literature. It appeared that comparable deficiencies in nursing pain assessment were described by, for instance, Camp-Sorrell and O'Sullivan (1991), Dalton (1989) and Paice et al. (1991). The phenomenon of patients' inhibition in expressing pain was also demonstrated in several nursing, medical and cultural anthropology studies ${ }^{33}$ (e.g. Carr, 1990; Juhl et al., 1993; Madjar, 1985; Shuter \& Miller, 1982; Ward et al., 1993; Ward \& Gatwood, 1994; Zborowski, 1969). Nurses' feelings of powerlessness in giving psychosocial support were described by Clements and Cummings (1991) and Fagerhaugh and Strauss (1977). The

\footnotetext{
33. Cultural anthropology studies often focused on differences in pain expression between people with different cultural backgrounds. Probably as a result of the fact that nearly all nurses and patients interviewed had a Dutch, caucasian background (also see Tables 3.1 and 3.2) these differences were not apparent in the needs assessment presented.
} 


\section{Chapter II}

limited use of certain physical and relaxation interventions have been corroborated by, for example, Dalton (1989), McCaffery (1990) and Schuurmans et al. (1993). The problems with pharmacological pain management are confirmed by several authors, among whom Fothergill-Bourbonnais and Wilson-Barnetl (1992) and McCaffery and Ferrell (1992).

In conclusion, several parallels were found between the findings from the needs assessment and other recent studies. This was a confirmation that our findings were of relevance, and could be a starting point for the development of a program plan.

The impact of the program. After the needs assessment study, a pilot study (Chapter 5) was carried out. From this pilot study, a first indication of the effectiveness of the pain CE program was obtained. In a subsequent controlled intervention study (Chapters 6-9), the effects of the program were further explored. The research questions addressed in this study could be summarized as follows:

Does the CE program result in an improvement of nurses' outcomes related to pain assessment and management, and in an improvement of patients' outcomes related to pain?

It was established that the program partially had the expected positive impact on nurses' ourcomes. As is shown in Table 11.1, the CE program did result in an increase in the quality of nurses' activities related to taking pain histories. In addition, nurses' attitudes towards physical and relaxation interventions, and the quality of these interventions improved as well. It was further established that the quality and duration of psychosocial interventions improved. The program also led to more knowledge of pain medication, to an increase in the quantity of nonopioid analgesics administered, and to an improvement of the quality of analgesic administrations. As indicated in Chapter 8, the increase in quality of analgesic administrations was probably partially due to the influence nurses have on doctors' prescriptions. Because after the program, nurses questioned patients more thoroughly about their pain (see Chapter 6 ), they may have been in a better position to provide doctors with more information on the patients' pain and the need for pain medication.

Although most positive effects diminished somewhat with time, they were still observable six months after the CE program. This indicates long term usage by nurses of parts of the program.

However, as also shown in Table 11.1, no effects were ascertained with respect to nurses' attitudes towards psychosocial interventions. Neither were positive effects ascertained with regard to the numbers of assessment activities and psychosocial, physical and relaxation interventions although, as previously stated, the quality of these activities and interventions did change significantly. These findings suggest that program participants find it more important to practice more intensive pain interventions of a higher quality, than to perform a greater number of these interventions. 
T2ble 11.1. Overview of murse outcomes and effects theasured in the controlled intervention study.

\begin{tabular}{|c|c|c|c|}
\hline Domain & Outcome variable & Dimension & Efled? \\
\hline \multirow[t]{5}{*}{ Pain assessment } & \multicolumn{2}{|l|}{ direct questioning } & no \\
\hline & \multirow{2}{*}{$\begin{array}{l}\text { pain intensity assessments by } \\
\text { rating scales }\end{array}$} & number & no \\
\hline & & quality & no \\
\hline & \multirow{2}{*}{$\begin{array}{l}\text { other activities related to } \\
\text { taking pain histories }\end{array}$} & number & no \\
\hline & & quality & $\begin{array}{l}\text { yes } \\
p<0,00 t\end{array}$ \\
\hline \multirow{10}{*}{$\begin{array}{l}\text { Psychosocial and } \\
\text { physical/relaxation } \\
\text { interventions }\end{array}$} & \multirow[t]{2}{*}{ attitudes towards } & psychosocial interventicrns & no \\
\hline & & $\begin{array}{l}\text { physical/rels xation } \\
\text { interventions }\end{array}$ & $\begin{array}{l}\text { yes } \\
p<0.001\end{array}$ \\
\hline & \multirow{3}{*}{$\begin{array}{l}\text { general psychosocial } \\
\text { interventions }\end{array}$} & number & no \\
\hline & & duration & $\begin{array}{l}y<x \\
p<0.001\end{array}$ \\
\hline & & quality & $\begin{array}{l}\text { yes } \\
p<0.001\end{array}$ \\
\hline & \multirow{3}{*}{$\begin{array}{l}\text { pain-focused psychasocial } \\
\text { interventions }\end{array}$} & number & $m$ \\
\hline & & duration & $\begin{array}{l}\text { yea } \\
p<0.00 i\end{array}$ \\
\hline & & quality & $\begin{array}{l}\text { yes } \\
p<0001\end{array}$ \\
\hline & \multirow{2}{*}{$\begin{array}{l}\text { physical/relaxation } \\
\text { inderventions }\end{array}$} & number & no \\
\hline & & qualicy & $\begin{array}{l}\text { yes } \\
p<0.001\end{array}$ \\
\hline \multirow[t]{6}{*}{$\begin{array}{l}\text { Pharmacological paip } \\
\text { managemend }\end{array}$} & \multicolumn{2}{|l|}{$\begin{array}{l}\text { koowledge of } \\
\text { analgesics }\end{array}$} & $\begin{array}{l}y=3 \\
p<0.001\end{array}$ \\
\hline & \multirow{4}{*}{$\begin{array}{l}\text { qunnticies of analgetics } \\
\text { sministered }\end{array}$} & spinal opioids & no \\
\hline & & epinal local ensesthetics & no \\
\hline & & intramuscular opioids & no \\
\hline & & nonopioids & $\begin{array}{l}y e s \\
\rho=0,04\end{array}$ \\
\hline & \multicolumn{2}{|l|}{$\begin{array}{l}\text { quality of amalgexic } \\
\text { administrations }\end{array}$} & yes \\
\hline
\end{tabular}

The program also had a positive impact on patients' outcomes. After nurses participated in the CE program, the intensity of surgical colon and breast cancer patients' pain decreased (see Table 11.2). It remains unclear, however, whether the decrease in 
pain intensity can be attributed to positive changes in pharmacological pain management, or to changes in nurses' psychosocial, physical and relaxation interventions. Future research may provide more insight into this question (see 'Recommendations for researchers').

Table 11.2. Overview of patienl outcomes and effects measured in the conurolled intervention sudy.

\begin{tabular}{|c|c|c|c|}
\hline Domain & Variable & Dimension & Efloa? \\
\hline \multirow[t]{6}{*}{$\begin{array}{l}\text { Phin-related outcomes in } \\
\text { patients }\end{array}$} & \multirow[t]{3}{*}{ Postoperative pain } & inkensity & $\begin{array}{l}\text { yes } \\
(p=0.02)\end{array}$ \\
\hline & & $\begin{array}{l}\text { number of hours of } \\
\text { pain }\end{array}$ & no \\
\hline & & $\begin{array}{l}\text { number of sleepless } \\
\text { hours as result of } \\
\text { pain }\end{array}$ & no \\
\hline & \multirow[t]{2}{*}{ psychological tule } & onxiay & no \\
\hline & & mood disturbances & no \\
\hline & \multicolumn{2}{|l|}{ Eength of hospicalization } & no \\
\hline
\end{tabular}

Although pain intensity did decrease, the pain duration, number of sleepless hours as a result of pain, state anxiety, mood disturbances, and duration of hospitalization did not change significantly (see Table 11.2). It can be assumed that the changes in pain intensity were too moderate to have consequences for the other outcome variables mentioned. Besides, with respect to duration of hospitalization, it must be noted that nowadays patients discharge from hospital as soon as possible. Therefore, it may not have been realistic to expect changes on this outcome variable. One may wonder whether other variables related to patients' recovery process, such as extent of ambulation or selfcare performances, are more appropriate.

The overall conclusion is that the program had a positive, but moderate impact on both nurses and patients; less than half of all the outcome variables measured were positively affected by nurses' participation in the program. It should be noted, that the majority of other studies on pain CE programs did report positive effects on almost all outcome variables (Davis, 1988; Degner et al., 1982; Ferrell et al., 1993, Foglesong, 1983; Foglesong et al., 1987; Hauck, 1986; Meyerink et al., 1994; Myers, 1985; Sofaer, 1984; Weissman et al., 1991 and 1993; Westfall \& Speedie, 1981). However, a main difference is that in our program much attention was paid to psychosocial, physical and relaxation interventions, while most other programs only paid attention to aspects of pain assessment or pharmacological pain management. In connection with this, the outcome variables used in other studies were only partially overlapping with variables assessed in the controlled intervention study presented. In addition, program conditions and circumstances will always differ, which could also explain why some programs appeared to be more successful than our's (Francke et al., 1995). Furthermore, the research methods varied. A main difference is that a control group and procedures for eliminating the influence of confounding variables (see section 'Methodological reflections on the controlled intervention study'), were not utilized in the majority of other studies. 
However, such procedures improve the internal validity of results. Our assumption is that methodological weaknesses provide a main explanation for the fact that most other studies report more positive results.

Clinical relevance. In considering nursing CE research it is always important to establish whether the effects of a program have clinical relevance. However, it is often difficult to evaluate the clinical relevance of changes in nurses because it is not always clear whether these changes, in turn, affect patient outcomes. This is why below attention is focused on the clinical relevance of effects measured in patients.

Colon cancer patients' pain intensity for the second postoperative day was 0.4 lower ${ }^{36}$ after the program than before (see Chapter 9). In the group of breast cancer patients, the pain intensity for the second postoperative day was 1.0 lower after the program. No criteria or consensus exist which can be used to judge whether a decrease in patients' pain intensity after a CE program is clinically relevant. However, in medical research on the effects of new analgesics a drop of less than 2.0 (on a ten point scale) is generally considered as clinically irrelevant. In that type of research a severe criterium is needed: when a new analgesic is introduced it has to be very obvious that this medicine is better than previous ones. It can be questioned, however, whether the same criterium is appropriate within the framework of research on the effects of a pain CE program for nurses. In the case of $\mathrm{CE}$ directed to nurses, it is realistic to expect moderate positive changes in patient outcome variables. After all, programs focusing on nurses can only have an indirect effect on patients. Still, CE prograins are valuable even when they have only a moderate impact on individual patients. A nurse who has been trained in a CE program may care for hundreds of patients a year. If all these patients experience somewhat less pain, this is certainly of value. Therefore, in our opinion, the assessed decrease in pain intensity has clinical relevance.

Findings of the qualitative evaluation interviews. In addition to the quantitative controlled intervention study, qualitative evaluation interviews with participants were held (see Chapter 10). The following research question was addressed in the interviews:

According to nurse participants, what factors affected the application of what had

been learned in the CE program positively or negatively?

Participants indicated that the fit between their personal view on pain management and the program was probably the main determinant of their use of the program in nursing practice. An 'integrated view' on pain management fitted very well, while a 'pharmacological view' fitted badly with the program content. Consequently, nurses with an integrative view made use of what they had learned in the program and nurses with a pharmacological view did not.

Participants also indicated that their attitudes towards the program and innovations in general, self-efficacy perceptions, and (un)familiarity and taboos with respect to program items had influenced what they put into practice. Furthermore, social interactions in the work environment, and practical-organizational factors were mentioned as

\footnotetext{
\$. Within a theoretical range of $0-10$, and within actual ranges of $2.3-4.7$ and $1.2-2.8$ for surgital breast and colon cancer patients respectively (see also Table 8.2).
} 
influential.

Several of the aforementioned influential factors (e.g. attitudes and self-efficacy perceptions) have received much attention in social psychology and health education (e.g. Bandura, 1986; De Vries \& Backbier, 1995). However, little was known about the possible influence of these factors within the framework of nursing pain CE programs. The qualitative interviews therefore supplement previous nursing CE studies.

\section{Methodological reflections}

Methodological reflections on the needs assessment study. The methods used in the needs assessment study (Chapter 3), i.e. participant observations and interviews, were characterized by intense contact with the research subjects. This contact provided useful information on nurses' $C E$ needs with respect to pain assessment and management. The fact that observations and interviews were combined in the needs assessment study was beneficial. Interviews shed particularly light on subjects' own perceptions of CE needs ('felt needs', see Kristjanson \& Scanlan, 1989), observations gave insight into CE needs of which the subjects involved were not always aware ('observed needs'). That both nurses and patients were involved was also beneficial. Patients' perspectives sometimes add to those of nurses, resulting in a more complete picture.

A benefit of qualitative approaches in general is that they are appropriate for research in new areas. In the period of the needs assessment study (1989-1990) not as much research was conducted within the field of pain assessment and management as there is now. Related to this, no Dutch-languaged quantitative instruments were available which could be used to assess learning needs. In such cases qualitative methods are the best alternative to obtain valid descriptions of a phenomenon (Van Dongen-Melman, 1995: Smaling, 1996).

The choice that was made at that time to interview breast cancer patients was the result of several considerations. The main reason was that breast cancer patients form a large group with a high pain incidence (see Chapter 3). However, if this study had to be carried out again, we would probably interview a more heterogenous group of surgical cancer patients. As the pain CE program focused on pain assessment and management in all types of surgical cancer patients, interviewing a more heterogenous group would have been more logical. Besides, this probably would have provided an even broader insight into $\mathrm{CE}$ needs concerning pain assessment and management.

Methodological reflections on the pilot study. In retrospect, the pilot study has also been of much value. As is described in Chapter 5, this small-scale study indicated that several adjustments of the CE program and evaluation instruments were necessary. The pilot study also gave positive indications about the program's effectiveness on nurses' pain assessment and management, justifying the start of a larger, controlled intervention study. 
Methodological reflections on the controlled intervention study. The majority of previous studies on pain $\mathrm{CE}$ programs showed considerable methodological limitations. Control groups, long term follow-up measurements, procedures for eliminating the influence of confounding variables (Rothman, 1986), and established instruments were not often used (see Chapter 2). In general, the more reliable the research methods, the more definitely it can be established that positive changes are the result of a particular intervention. Therefore, wherever possible research methods were chosen which could be considered in a methodological sense- as 'strong'. The main characteristics of these methods are briefly discussed below.

Design. When the scientific knowledge about the effectiveness of a program is meager, it is worthwhile to investigate the effectiveness of a program as a whole (Bouter \& Van Dongen 1988; Horvath, 1988). The design chosen, i.e. a design with one experimental condition (CE program) and one control condition (no CE program), is appropriate in such cases.

Measurements were made just before the start, one month after and six months after the CE program, in both experimental and control nurses. In addition, effects were measured before and after the CE program among patients in the experimental and control condition. Because the follow-up tests were performed rather long after the end of program, insight was also gained into the impact of the CE program in the long run.

Procedures to eliminate confounding. To reduce the influence of confounding variables and to enhance internal validity (Rothman, 1986), nursing wards were randomly allocated to the experimental or control condition. Randomization at ward level seemed more appropriate than randomization of individuals; when wards are randomly allocated the chance of 'contamination of treatment' is less great ${ }^{37}$ (Diwan et al., 1992). However, because there were only ten wards involved, randomization at ward level did not give complete certainty regarding the comparability of experimental and control subjects. Yet it diminished the chance that, for instance, the highest motivated, or most prominent, ward teams were all allocated to the experimental condition, and other ward teams to the control condition.

Restriction of the inclusion criteria for research subjects was another procedure used to eliminate confounding. Our expectation was that the influence of a particular work environment would interact with the effects of the CE program (Francke et al., 1995). Therefore, the nurse population was restricted to those working on the same type of wards (i.e. surgical cancer wards). With respect to patient data, it was expected that the impact of the CE program would be influenced by the type of disease and surgery. For this reason, the patient population was restricted to only two patient categories (i.e., surgical colon and breast cancer patients).

After data collection, statistical adjustments were made for confounding variables. It was expected that characteristics of a hospital (e.g. regarding the medical pain policy in the hospital) may be partially responsible for changes in nurse outcome variables.

"n. In theory, even in the case of randomization of wards, nurses could exchange new knowledge and skills with nurses from another ward. However, in the first session of the program, participants received an explanation of why it was important that they did not tell nurses from the control wards what they learned in the program. After that, nurse participants had to promise secrecy during the research period. 


\section{Chapter II}

Therefore, the variable 'Hospital' was treated as a covariate in the MANCOVA procedure. Statistical adjustments for 'Hospital' and several other covariates were also made for the patient data (see Chapter 9).

Instruments. Wherever possible, established instruments were used to measure the effects of the CE program. Several valid and reliable tests were available which could be used to measure pain-related outcomes in patients (see Chapter 9). Established instruments for nurses that suited items dealt with in the CE program were however scarce, and some new instruments had to be constructed (see Chapters 6-8). It is important to study psychometric qualities particularly in the case of new instruments. Therefore, content validity of the self-constructed instruments was established by pain experts, and the questionnaires' practicability and comprehensibility was tested on subjects of the pilot study (see Chapter 5) and in a group of nurses not involved in other parts of the project. The definitive structure and internal consistency was determined using the data of the controlled intervention study (see Chapters 6-8).

Most questionnaires used for measuring effects in nurses were the 'self-report type' (see Chapters 6 and 7). In principle, self-report questionnaires can give a somewhat distorted view of actual effects. For example, nurses might feel obligated to say that they practice certain interventions. This could result in socially desirable, overly positive answers. To determine whether such a phenomenon may have occurred, correlations were calculated between the scores on the self-report questionnaires and social desirability scores (determined by items of the Marlowe Crowne Social Desirability Scale, Bruggemans \& Maes, 1986). The correlations were low (all correlation coefficients were lower than 0.30), which suggests that there was little distortion caused by social desirability patterns.

Statistical validity of effects. A relevant question is whether the results are statistically valid. In other words, what are the chances that the findings are 'falsenegative' or 'false-positive' (respectively Type II and Type I-errors, see Polit \& Hungler. 1987)? False negative findings can be caused by too small a sample: the chance of significant results in a small sample is less than in a large sample. In the controlled intervention study there were a lot of outcome variables (see Tables 11.1 and 11.2). which impeded the determination of sample sizes by power analysis. Because of this fact. sample sizes were mainly determined on the basis of practical considerations related to financial sources. However, several significant outcomes were established, which indicated that the sample sizes were adequate. Probably more significant results would have been found using larger samples. Still, it remains a question whether this would have yielded relevant information. After all, in very large samples, even minimal effects may lead to statistically significant results that are clinically irrelevant (Francke \& Duivenvoorden, 1993).

It is more difficult to say whether there were false positive effects for some outcome variables. For all outcome variables the significance level was set at .05 (see Chapters 6-9). In such a case, one out of twenty tests will be coincidentally significant, provided that the outcome variables are not inter(cor)related. In the controlled intervention study there were many outcome variables and dimensions (see Tables 11.1 and 11.2), which seemed to be related in terms of content. However, the correlation 
between them was not really substantial (in all cases lower than .55$)^{38}$. This indicates that the intercorrelation, and therefore also the chance of false positive findings, is acceptable.

Methodological reflections on the qualitative evaluation interviews. The qualitative evaluation interviews only gave insight into the participants' perceptions. Therefore, it remains unclear whether factors mentioned by participants (e.g. limited time or lack of qualified personnel) are real determinants of program application or only rationalizations. Despite the aforementioned limitation, the evaluation interviews proved to be valuable. It was advantageous that the participants' ideas about influencing factors were explored, since the CE program did not produce the anticipated effects in all respects. Without this information, it would have been much more difficult to provide practical recommendations for educators, managers and others involved (see below).

\section{Recommendations}

Recommendations for initial educators. As described, a number of the participants had a strictly pharmacological view on pain management. This fact provided the main explanation for the moderate program success (see Chapter 10). A pharmacological view not only has limited correspondence with the CE program content, it also discorresponds with current professional and scientific insights on pain relief (see McCaffery \& Beebe, 1989; VWR/C.BO, 1994). Therefore, a more integrated view on pain management has to be developed as early as possible in nursing education. Initial educators must become aware of their model function for student nurses. The value that educators place on a combination of pharmacological and nonpharmacological pain interventions may form a determining factor for student nurses' views on pain management. Initial educators should also familiarize their students with nursing interventions such as massage, relaxation and distraction. In this respect, discussions about patient cases and practical exercises may be very useful. It is essential that during these discussions and exercises attention is paid to how the relevant interventions can be applied in nursing practice. This would promote an integrated view on pain management, and may provide a good foundation for pain $\mathrm{CE}$ programs during later professional life.

The next recommendation for initial educators concerns the use of educational methods. According to the two program instructors of the pain $\mathrm{CE}$ program, some of the participants had resistance about expressing their learning needs. This was most apparent among participants with a pharmacological viewpoint. These participants failed to express their desire to spend more time on learning about pharmacological items until the last session. Participants' resistances to express learning needs may be related to their unfamiliarity with Confluent Education (see Chapter 4) or other methods in which students have considerable influence on the learning process. Several authors (e.g. Parfitt, 1989; Popiel, 1977) have pointed to the importance of such 'student-directed methods' for

m. In the case of a correlation of 0.55 the explained variance is 0.30 . Still, the unexplained variance is 0.70 . Therefore, even a correlation of 0.55 can be considered as 'not really substantial." 
nursing education, because they call upon the individual student's capacities and responsibilities. If nurses were to become acquainted with student-directed methods from the very beginning of their training. it would be easier for them to express learning needs during later CE programs.

Recommendations for CE organizers and nursing managers. Nurses often consider it a pleasure to participate in CE programs with all their close colleagues (see Chapter 10). Therefore, educating nurses in teams is in many cases recommended. However. precondition for team-based participation may be that most team members have personal views which correspond with the $C E$ program and have no resistances to program participation. Whenever this precondition is not met, it seems wise to opt for participation by only a few individual nurses. It might even be better to postpone programs in situations where there are resistances related to lack of clarity about compensation for hours, personnel replacement, or other program conditions (see Chapter 10). In these cases, arrangements between program organizers, higher and middle nursing management and nurse participants have to be made first ${ }^{39}$. Nurses' motivation for $C E$ may increase if they feel that adequate arrangements have been made, and that organizers and managers are really attentive to their practical-organizational needs.

Probably as a result of uncertainty, nurses often force responsibilities regarding the use of new approaches upwards in the hierarchy (Menzies, 1960; Lima Basto, 1994). Related to this, nurses consider formal program implementation initiated by nursing managers (e.g. division managers and coordinating head nurses) as a prerequisite for regular use of program content. Whatever one thinks about forcing responsibilities to higher hierarchical layers, it can not be denied that formal implementation is important. Nursing managers must therefore take responsibility for translating $C E$ programs into ward policy. In this regard, it may be most effective to let nursing managers participate in the C.E program as well. In addition, it may be effective to directly connect the CE program with formal innovations, e.g. the implementation of a new pain assessment or management policy. An example of a new pain assessment policy is the implementation of protocols or standards which include regular pain intensity or pain history assessments (Bookbinder et al., 1995; Davis, 1988; Hamers, 1995; McCardle \& Van der Wiel, 1993; De Wit \& Van Dam, 1991). A new policy for pain management may be the implementation of scheduled analgesics (Degner et al., 1982), or protocols for nonpharmacological pain interventions. Of course, also such formal innovations only work if ward nurses and other health care workers involved broadly support them.

". Prior to the pain CE program, the organizer/researcher (A.L.F.) had emphasized to the nursing maragers involved that compensation of hours and replacement of personnel were necessary. Still, in three of the five participating hospitals problems occurred in this respect (see Chapter 10). Based on these experiences, it seems necessary that not only verbal, but also written agreements be made. The latter agreements may create more clarity betwetn the 'negotiating' partners, and may be better transferable to all parcicipants. 
Interdisciplinary recommendations. As described in Chapter 10, the cooperation between nurses particularly with medical care providers may influence the application of pain CE programs. Interdisciplinary cooperation in which care providers supplement each others work, rather than working independently, has to be promoted. An important step in the right direction would be that nurses clarify their (possible) contribution to adequate pain management to other disciplines. This could happen in the course of daily interactions and also within the framework of interdisciplinary pain teams or services. Such interdisciplinary groups have a variety of goals (see Rawal \& Berggren, 1992), such as setting up interdisciplinary pain protocols and promoting the growth of professionals' expertise. The participation of nurses in such teams would provide a unique opportunity to integrate insights gained during pain C.E programs into a common policy. In this way, CE programs will not function as isolated courses, but will contribute to the development of interdisciplinary care for patients in pain.

In addition, it may be worthwhile to organize interdisciplinary pain programs in which physicians and nurses participate together. However, not all nurses or institutions may be ready for interdisciplinary CE. If nurses do not have sufficient insight into their own specific possibilities in pain assessment and management, it may be a step too far for them to contribute to, and to participate in, an interdisciplinary pain program.

Recommendations for researchers. As is the case in every scientific study, the research presented leads to several new questions.

To begin with, the evaluation interviews (Chapter 10) demonstrated that personal views on pain management may strongly determine the success of CE programs. One can assume that personal views on the central program theme would also play an important role within the framework of other CE programs. Therefore, insight into personal views should be obtained whenever possible, e.g. by means of interviews or questionnaires ${ }^{*}$. Systematically establishing the views of all the participants would make it possible to investigate to what extent personal views determine the effectiveness of CE programs. Besides, if information on participants' views is gathered prior to a CE program, better grounded decisions about subject matter and 'team or individual participation' could be made.

As described, the evaluation interviews also indicated that participants consider formal implementation important for program application. It is relevant to investigate whether a similar CE program combined with formal implementation of a new pain policy has a larger impact. A lack of cooperation with the medical profession in particular was indicated as another factor impeding program use. Therefore, it is also interesting to investigate whether a similar CE program which is accompanied by clear arrangements with other professionals, or whether interdisciplinary pain C.E programs have more impact.

- The pharmacological and integrated view have many parallels with the so-called 'care and cure orientation', described by Bullough and Sparks (1975). Perhaps the Care and Cure Orientation Scale of Bullough and Sparks' can be of use for assessing participants' views. 
The evaluation interviews also pointed to the influence of several other factors on the programs' impact. By using complementary research mechods (e.g. participant or nonparticipant observations) or complementary sources (e.g. nurse supervisors), more insight can be gained into whether the factors mentioned by participants actually affect the use of pain CE programs. Furthermore, such research may provide insight into important influential factors not mentioned by participants.

The controlled intervention study has also left certain questions unanswered. As described, nurses had changed on several dimensions of psychosocial, physical, relaxation and pharmacological interventions. However, it is not completely clear to what program items and related changes in nursing interventions, the decrease in patients' pain intensity can be attributed. Future research using a design with several program variants (for instance, a program with, and a program without, nonpharmacological items) may shed more light on which program items are responsible for the positive impact on patients.

\section{References}

Bandura A (1986). Social foundations of thought and action. Englewood Cliffs NJ: Prentice Hall.

Bouter LM \& Van Dongen MCJM (1988). Epidemiologisch onderzoek. Opzet en interpretatie. Utrecht/Antwerpen: Bohn, Scheltema \& Holkema.

Bookbinder M, Kiss M, Coyle N, Brown MH, Gianella A \& Thaler HT (1995). Improving pain management practices. In DB McQuire. CH Yarbro \& BR Ferrell (Eds., 2nd edition). Cancer pain management (pp. 321-361). Boston: Jones \& Barlett.

Bruggemans E \& Maes S (1986). Psychosociale effecten van een lange-termijn sportprogramma bij coronaire hartpatienten. De Psycholoog XXI, oktober 1986, 497-498.

Bullough B \& Sparks C (1975). Baccalaureate versus associate degree nurses: the care-cure dichotomy. Nursing Ouslook 23, 688-692.

Camp-Sorrell LD \& O'Sullivan PS (1991). Effects of continuing education: pain assessment and decumentation. Cancer Nursing 14, 1, 49-54.

Carr ECJ (1990). Postoperative pain: patients' expectations and experiences. Joumal of Advanced Nursing. 15, 89-100.

Clements S \& Cummings S (1991). Helplessness and powerlessness: caring for patients in pain. Holistic Nursing Practice 6, 1, 76-85.

Dalton JA (1989). Nurses' perceptions of their pain assessment skills, pain management practices, and attitudes toward pain. Oncology Nursing Forum 16, 2, 225-231.

Davis PS (1988). Changing nursing practice for more effective control of postoperative pain through a staff initiated educational programme. Nurse Education Todory 8, 325-331.

Degner LF, Fujii SH \& Levitt M (1982). Implementing a program to control chronic pain of malignant disease for patients in an extended Polit, DF \& Hungler BP (1987). Nursing research. Principles and methods. Philadelphia: J.B. Lippincou Company.

Diwan VK, Eriksson B, Sterky G \& Tomson G (1992). Randomization by group in srudying the effect of drug information in primary care. International Joumal of Epidemiology 21, 1124-130.

Dongen-Melman JEWM van (1995). On surviving childhood cancer. Late psychosocial consequences for patients, parents and siblings. Alblasserdam: Haveka BV.

Fagerhaugh SY \& Strauss AL (1977). Politics of pain management: staff-patient interaction. Califormia: Addison-Wesley Publishing Company.

Ferrell BR, Grant M, Ritchey KJ, Ropchan R \& Rivera, LM (1993). The pain resource nurse training program: a unique approach to pain management. Journal of Pain and Symprom Management 8,8 . 549-556.

Foglesong DH (1983). The impact of a staft development offering on nursing practice. Joumal of Continuing Education in Nursing 14, 6, 12-15. 
Foglesong DH, Lambert J \& Emerick J (1987). Variables which influence the effect of staff development on nursing practice. Journal of Continuing Education in Nursing 18, 5, 168-171.

Fothergill-Bourbonnais F \& Wilson-Bannett J (1992). A comparative study of intensive therapy unit and hospice nurses' knowledge on pain management. Joumal of Advanced Nursing. 17, 362-372.

Francke AL \& Duivenvoorden HJ (1993). Methodologie van interventiestudies. Moeilijkheden. mogelijkheden en valkwilen. In AL Francke (Bd.), Verplegen, intervenieren en evalueren. Verpleegkundig interventie-onderzoek in de praktijk (pp.13-23). Lisse: Swets \& Zeitlinger.

Francke AL. Garssen B \& Huijer Abu-Saad H (1995). Determinants of changes in nurses' behavior after continuing education: a literature review. Joumal of Adwanced Nursing, 21, 371-377.

Hamers, JPH (1995). Postoperative pain in children. Assessment and insenvention. PhD-thesis. Maastricht: Datawyse.

Hauck S (1986). Pain: problem for the person with cancer. Cancer Nursing 9, 2, 66-76.

Horvath P (1988). Placebos and common factors in two decades of psychotherapy research. Psychological Bulletin 104, 2, 214-225.

Juhl IU, Christensen BV, Bülow HH, Wilbek H, Dreijer NC \& Egelund B (1993). Postoperative pain relief. from the patients' and the nurses' point of view. Acta Anoesthesiologica Scandinavica, 37, 404409 .

Kristjanson LJ \& Scanlan JM (1989). Assessment of continuing nursing education needs. Literature Review. The Journal of Continuing Education in Nursing 20, 3, 118-123.

Lima Basto M (1994). Implementing change in nurses' professional behaviours. Phd-Thesis. Lisboa: University of Lisboa.

Madjar I (1985). Pain and the surgical patient: a cross-cultural perspective. Australian Joumal of Adwanced Nursing 2, 2, 29-33.

McCaffery M \& Beebe A (1989). Pain. Clinical Manual for Nursing Practice. St. Louis-BaltimorePhiladelphia-Toronto: C.V. Mosby Company.

McCaffery M (1990). Nursing approaches to nonpharmacological pain control. Intemational Journal of Nursing Studies 27, 1, 1-5.

McCaffery M \& Ferrell BR (1992). Opioid analgesics. Nurses' knowledge of doses and psychological dependence. Journal of Nursing Staff Development, March/April, 77-85.

McCardle M \& Van der Wiel Y (1993). Erwaringen van wijkverpleegkundigen met het afnemen van de pijnanamnese bij patienten met kanker in de thuissituatie. Unpublished report. Nijmegen: Hogeschool Nijmegen en Integraal Kankercentrum Oost.

Menzies I (1960). The functioning of social systems as a defense against anxiety. Human Relations 13, 95121.

Meyerink G、Tjia PF, Golbach G, Van Aalst A \& Hulshof A (1994). Verslag project 'Werken met verpleegkundige pijnonamnese'. Unpublished report. Utrecht: Integraal Kankercentrum MiddenNederland.

Myers J (1985). Cancer pain: assessment of nurses' knowledge and attitudes. Oncology Nursing Fonum 12. 4. 62-66.

Paice JA. Mahon SM \& Faut-Callahan M (1991). Factors associated with adequate pain control in hospitalized postsurgical patients diagnosed with cancer. Cancer Nursing 14, 6, 298-305.

Parfitt BA (1989). A practical approach to creative teaching: an experiment. Journal of Adwanced Nursing 14, 665-677.

Polit DF \& Hungler BP (1987). Nursing research. Principles and methods. Philadelphia: J.B. Lippincott Company.

Popiel ES (ed.) (1977, 2nd edition). Nursing and the process of continuing education. St Louis: CV Mosby company.

Rawal N \& Berggren L (1994). Organization of acute pain services: a low-cost model. Pain, 57, 117-123.

Rothman KJ (1986). Modern epidemiology. Boston, Massachusetts: Little, Brown and Company.

Schuumans J. Wulferink A \& Boer H (1993). Pijn bij kanker: opvattingen van verpleegkundigen. Tijdschrift woor Ziekenverpleging, 3, 97-100.

Shuter R \& Miller FJ (1982). An exploratory study of pain expression among blacks and whites. 


\section{Chapter II}

International Journal of Intercultural Relations; 6, 281-290.

Smaling A (1996). De relevantie van de argumentatietheorie voor kwalitatief onderzoek. Xwalon. Tijdschrift voor Kwalisatiof Onderzok in Nederland 1, 1, 4-8

Sofact B (1984). The effect of focused education for nursing teams on postoperative pain of patients. Unpublished PhD-thesis. Edinburgh: University of Edinburgh.

Vries H \& Backbier EHF (1995). Verklaring en verandering van gedrag: een beschouwing van het transtheoretische model. Tijdschrift voor Gezondheidsbevordering 16, 26-34.

VWR/CBO (1994). Syllabus bij de consensusbijeenkomst 'Verpleegkunde bij pijn'. Utrecht: CBO.

Ward SE, Goldberg N, Miller-McCauley V, Mueller C, Nolan A, Pawlik-Plank D, Robbins A, Stormoen D \& Weissman DE (1993). Patient-related barriers to management of cancer pain. Pain, 52, 319-324.

Ward S \& Gatwood J (1994). Concerns about reporting pain and using analgesics. A comparison of persons with and without cancer. Cancer Nursing 17, 3, 200-206.

Westfall LK. \& Speedie SM. (1981). The effects of inservice education provided by consultant pharmacists on the behavior of nurses in long-term care. facilities. Drug Intelligence and Clinical Pharmacy IS. 777-781.

Weissman DE, Gutmann M \& Dahl JL (1991). Physician cancer pain education: a report from the Wisconsin Cancer Pain Initiative. Journal of Pain and Symptom Management 6, 7, 445-448.

Weissman DE Dahl JL. \& Beasiy JW (1993). The Cancer Pain Role Model Program of the Wisconsin Cancer Pain Initiative. Journal of Pain and Symptom Management 8, 1. 29-35.

Wit R de \& Van Dam, PSAM (1991). Verpleegkundige pijnmeting bij kankerpatienten: een interventiestudic. Verpleegkunde. Nederlands-Vlaams Wetenschappelijk Tijdschrifit voor Verpleegkundigen 62 68-75.

Zborowski M (1969). People in pain. San Francisco: Jossey-Bass. 
SUMMARY 


\section{SUMMARY}

Many nurses today participate in continuing education (CE) programs. This dissertation sheds more light on whether $\mathrm{CE}$ on pain benefits nurses' knowledge and attitudes regarding pain management. Moreover, it gives insight into whether $\mathrm{CE}$ on pain provides an opportunity to improve nurses' pain interventions in practice and patient outcomes related to pain.

The first chapter presents background information on CE in nursing. Within this framework, the following definition of CE is discussed: "Planned learning experiences beyond a basic nursing educational program designed to promote the development of knowledge, skills and attitudes for the enhancement of nursing practice, thus improving health care to the public". In addition, a picture is painted of how CE programs emerged in the 20th century. As a result of nurses' process of professionalization, and significant developments in science, society and health care nurses felt a strong need for CE. The chapter closes with some recommendations for future evaluation studies on the effects of $\mathrm{CE}$ programs. Since the ultimate aim of $\mathrm{CE}$ in nursing is the improvement of health care to the public, a plea is made that in the future not only effects on nurses, but also on patients be examined.

A literature review of studies on the effects of pain C.E programs directed to nurses is presented in Chapter 2. Most of the sixteen programs reviewed focused on aspects and characteristics of pain, analgesics or pain assessment. Few programs also paid attention to interventions such as provision of information and support, massage and relaxation. A remarkable finding, since these nonpharmacological interventions fall under the domain of nursing. Critical comments were also made in this chapter with respect to the methods used to evaluate the programs. Randomized control groups, inferential statistics, follow-up measurements and established instruments, were rarely used. Effects reported were for the most part positive. Nearly all authors report positive effects on nurses' attitudes, knowledge or interventions related to the assessment and management of pain. The four studies in which patient outcomes were also assessed, all showed some beneficial effects on pain intensity or other outcome variables directly related to pain. The conclusion of this chapter is, however, that given the small number of published studies and their methodological limitations, further research into the effectiveness of pain CE programs is indicated.

Chapter 3 presents a needs assessment study prior to a $\mathrm{CE}$ program on pain assessment and management directed to surgical cancer nurses. Participant observations and qualitative interviews pointed to several $\mathrm{CE}$ needs. Although nurses considered pain assessment as an important nursing task, few nurses assessed pain systematically and thoroughly. In addition, some nurses were unaware of the effectiveness of certain nonpharmacological techniques, and often felt powerless in giving psychosocial support. Furthermore, nurses often gave insufficient and too irregular pain medication, which was connected to patients inhibition about expressing pain and asking for pain alleviation.

Chapter 4 reflects on Confluent Education, the educational method used in the pain CE program. In the first part of the chapter attention is focused on general characteristics of this method. The second part is devoted to how Confluent Education was applied in the aforementioned CE program. An important statement in this chapter is that the 'confluence' of affective and cognitive learning is especially important in CE on pain. This confluence may promote that nurses value patients' personal experiences and feelings 
related to pain, as well as their physical needs.

A pilot study is discussed in Chapter 5. The pilot study was used to gain indications of the program's effectiveness, and to develop the definitive CE program plan and evaluation instruments.

After the pilot study, a large controlled intervention study was started. In the latter study, effects of the program were measured in a pretest-posttest control group design. Randomization took place at ward level: in each of the five participating hospitals two nursing wards were randomly allocated to the experimental condition (program) or to the control condition (no program). In the subsequent four chapters the results of the controlled intervention study are discussed. First of all, the effects of the CE program on aspects of nurses' pain assessment practices are presented in Chapter 6. Analyses revealed that the program led to an increase in the quality of nurses' activities relevant to taking pain histories. However, no effects on the number of activities relevant to taking pain histories, and the number of nurses who used direct questioning as a method to determine pain were established.

In Chapter 7 the effects of the CE program on nurses' psychosocial, physical and relaxation interventions are described. It was established that the program resulted in more positive attitudes towards physical and relaxation interventions (use of massage, relaxation, distraction, cold, heat and comfort measures). In addition, the program resulted in an increase in the quality of physical and relaxation interventions. Furthermore, the program led to an increase in the duration and quality of psychosocial interventions (provision of information and emotional support, and promotion of autonomy). However, the program did not lead to more positive attitudes towards psychosocial interventions, nor to increases in the numbers of psychosocial, physical and relaxation interventions.

Chapter 8 presents the effects of the CE program on aspects of pharmacological pain management. It was found that the program led to an increase in nurses' knowledge of pain medication, to an improvement of the quality of analgesic administrations, and to an increase in the quantity of nonopioids administered. The program had not, however, resulted in significant changes in the quantities of opioid analgesics and local anaesthetics administered.

Chapter 9 deals with effects of the CE program on patient outcomes. Surgical colon and breast cancer patients admitted after nurses had participated in the CE program. experienced lower pain intensity than comparable patients previously admitted. No effects were found. however, on pain duration, sleepless hours as a result of pain, state anxiety, mood disturbances and duration of hospitalization.

In Chapter 10 attention is paid to participants' perceptions concerning factors which influenced the application of the $C E$ program in nursing practice. In qualitative interviews participants indicated that the extent to which the CE program corresponded with their personal view on pain management was a very influential factor. Besides, their attitudes towards the program and innovations in general, self-efficacy perceptions, familiarity and taboos with respect to program items would have influenced what they applied in practice. Moreover, participants indicated that interactions with colleagues. nursing managers, patients and physicians affected their application of the program. Furthermore, organizational factors, such as a lack of translation of the program into 
ward policy, were mentioned as influential.

Finally, in the General Discussion methodological characteristics of the needs assessment study, pilot study, controlled intervention study and qualitative evaluation interviews are discussed. In addition, reflections are made on the research findings of the different studies. The main conclusion is that the CE program has had a beneficial, but rather moderate, impact on nurses and patients. The chapter closes with recommendations for nursing practice, education and research. 
SAMENVATTING 


\section{SAMENVATTING}

Veel verpleegkundigen volgen bijscholing op het gebied van pijn en pijnbestrijding. Dit proefschrift werpt meer licht op de vraag of pijnbijscholing een gunstig effect heeft op kennis en attitudes van verpleegkundigen. Bovendien geeft het inzicht in de effecten van pijnbijscholing op interventies van verpleegkundigen èn op kenmerken van patiënten die samenhangen met pijn.

Hoofdstuk 1 geeft algemene informatie over bijscholing in de verpleging. In dit kader wordt de volgende definitie van bijscholing gepresenteerd: "Geplande leerervaringen na het verpleegkundig basisonderwijs, bedoeld om de kennis, vaardigheden en attitudes van verpleegkundigen verder te ontwikkelen teneinde een bijdrage te leveren aan de verpleegkundige praktijk en de gezondheidszorg". Daarnaast wordt beschreven hoe verpleegkundigen in de laatste decennia geconfronteerd werden met nieuwe wetenschappelijke en verpleegkundige inzichten en met immense veranderingen in de gezondheidszorg. Daardoor gingen verpleegkundigen steeds meer de noodzaak voelen om zich bij te scholen. Het eerste hoofdstuk wordt afgerond met aanbevelingen voor nader onderzoek naar de effectiviteit van pijnbijscholing voor verpleegkundigen. Daarbij wordt gesteld dat er meer onderzoek moet worden gedaan naar de effecten op patiënten. Op die manier kan inzicht worden verkregen in de mate waarin het uiteindelijke bijscholingsdoel, een positieve bijdrage leveren aan de gezondheidszorg, bereikt is.

In Hoofdstuk 2 wordt een literatuuroverzicht gepresenteerd van studies naar pijnbijscholing voor verpleegkundigen. In het merendeel van de zestien bestudeerde bijscholingsprogramma's heeft men zich gericht op kenmerken en aspecten van pijn, farmacologische pijnbestrijding of methoden om pijn vast te stellen. Slechts in enkele bijscholingsprogramma's werd ook aandacht besteed aan psychosociale, fysieke of ontspanningsinterventies. Dit is opmerkelijk omdat dergelijke niet-farmacologische interventies ook tot het competentiegebied van verpleegkundigen horen. Verder konden er kanttekeningen bij de effectmetingen van de betreffende bijscholingsprogramma's worden geplaatst. Er werd weinig gebruik gemaakt van gerandomiseerde controlegroepen, toetsende statistiek, 'follow-up' metingen en gevalideerde meetinstrumenten. De uitkomsten van de effectmetingen waren overwegend positief. Bijna alle studies rapporteren positieve attitude-, kennis-, of gedragsveranderingen bij verpleegkundigen. In de vier studies waar ook was gekeken naar de effecten van de pijnbijscholing op patiënten, werden gunstige effecten op de pijnintensiteit of andere kenmerken gerelateerd aan pijn vastgesteld. De conclusie van dit hoofdstuk is echter dat, gezien de methodische beperkingen en het beperkte antal verrichte studies, nader onderzoek naar de effectiviteit van pijnbijscholing gewenst is.

In Hoofdstuk 3 wordt een behoeftenonderzoek voorafgaande aan een pijnbijscholing voor chirurgisch-oncologische verpleegkundigen gepresenteerd. Door middel van participerende observaties en kwalitatieve interviews werden er verschillende knelpunten en leerbehoeften vastgesteld. Zo bleek dat ondanks het feit dat verpleegkundigen het vaststellen van pijn een belangrijke taak vonden, zij daarbij soms weinig systematisch te werk gingen. Daarnaast bleken sommige verpleegkundigen niet voldoende op de hoogte te zijn van niet-farmacologische pijninterventies en te kampen met gevoelens van machteloosheid. Ook kwam het voor dat pijnmedicatie onregelmatig en in te lage doseringen werd verstrekt. Dit hing samen met het feit dat veel patiënten geremd waren bij het uiten van pijn en het vragen om pijnmedicatie. 
Hoofdstuk 4 is gewijd aan Confluent Education, de onderwijsmethode die in de voornoemde pijnbijscholing werd gebruikt. Allereerst wordt ingegaan op algemene kenmerken van deze onderwijsmethode. Vervolgens wordt ingegaan op hoe de principes van Confluent Education zijn uitgewerkt in de pijnbijscholing. Tenslotte wordt uitgelegd waarom Confluent Education met name voor pijnbijscholing een geschikte onderwijsmethode is. Binnen Confluent Education is er namelijk zowel aandacht voor het bespreken van ervaringen, gevoelens en attitudes als voor uitbreiding van kennis en vaardigheden. Op deze manier kan worden bevorderd dat verpleegkundigen de persoonlijke ervaringen en gevoelens van patiënten met pijn respecteren en daarnaast ook aandacht hebben voor de fysieke behoeften van die patiënten.

In Hoofdstuk $S$ wordt een 'pilot study' beschreven. Door deze studie werd een eerste indicatie van de effecten van de pijnbijscholing verkregen. Daarnaast gaf de pilot study inzicht in de mate waarin het bijscholingsprogramma en de evaluatie-instrumenten bijstelling behoefden.

$\mathrm{Na}$ de pilot study ging een grootschalige interventiestudie van start. In deze studie werd in vijf ziekenhuizen de pijnbijscholing ingevoerd en geëvalueerd. Effecten van de bijscholing werden vastgesteld in een 'pretest-posttest controlegroep design'. In elk van de deelnemende ziekenhuizen werd één afdeling door het lot toegewezen aan de experimentele conditie (bijscholing) en een andere afdeling aan de controle-conditie (geen bijscholing). De resultaten uit de interventiestudie worden gepresenteerd in de volgende vier hoofdstukken. Zo worden in Hoofdstuk 6 de effecten van de pijnbijscholing op het vaststellen van pijn door verpleegkundigen besproken. De bijscholing bleek te hebben geleid tot een kwaliteitstoename van de activiteiten gerelateerd aan het afnemen van een pijnanamnese. Er konden echter geen effecten worden vastgesteld op het aantal van deze activiteiten. Ook werden er geen significante veranderingen vastgesteld in het aantal verpleegkundigen dat rechtstreeks bij patiënten informeerde naar pijn.

Hoofdstuk 7 gaat over de effecten van de pijnbijscholing op de psychosociale, fysieke en ontspanningsinterventies van verpleegkundigen. De bijscholing heeft geleid tot positievere attitudes van verpleegkundigen ten opzichte van fysieke en ontspanningsinterventies (het gebruik van massage, ontspanning, afleiding, warmte, koude en comfort bevorderende maatregelen). Ook bleek de bijscholing te hebben geleid tot een toename van de kwaliteit van deze interventies. Tevens bleek dat de bijscholing heeft geresulteerd in een verlenging van tijdsduur en een kwaliteitstoename van psychosociale interventies (informatieverstrekking, emotionele begeleiding en autonomiebevordering). De bijscholing heeft echter geen consequenties gehad voor de attitudes ten opzichte van psychosociale interventies of voor de aantallen psychosociale, fysieke en ontspanningsinterventies.

In Hoofdstuk 8 wordt ingegaan op de effecten van de pijnbijscholing op farmacologische pijnbestrijding door verpleegkundigen. $\mathrm{Na}$ de bijscholing hadden verpleegkundigen meer kennis over pijnmedicatie. Tevens bleek er na de bijscholing een toename te zijn van de kwaliteit van de pijnmedicatieverstrekkingen en van de hoeveelheid verstrekte niet-opiaten. Daarentegen konden er geen significante veranderingen worden vastgesteld in de hoeveelheid verstrekte opiaten en lokale anesthetica.

Hoofdstuk 9 is gewijd aan de effecten van de pijnbijscholing op patiënten. Chirurgische borst- en darmkankerpatiënten die na de bijscholing waren opgenomen 


\section{Samenvatting}

bleken minder hevige pijn te hebben dan vergelijkbare patienten opgenomen vo6r de bijscholing. Er waren echter geen significante veranderingen in pijnduur, aantal uren dat patiënten wakker lagen van pijn, toestandsangst, stemming en opnameduur.

In Hoofdstuk 10 wordt aandacht besteed aan factoren die mogelijk invloed hebben gehad op het gebruik van de pijnbijscholing in de praktijk. In kwalitatieve interviews noemden verpleegkundigen diverse beïnvloedende factoren. Zo zou de mate waarin de eigen visie op pijnbestrijding aansloot bij de bijscholing sterk bepalend zijn geweest voor toepassing van het geleerde. Ook de attiudes ten opzichte van de bijscholing en innovaties in het algemeen zou daar invloed op hebben gehad. Daarnaast zouden de mate waarin men zichzelf in staat achite om het geleerde toe te passen, (on)bekendheid en taboes een rol hebben gespeeld. Verder gaven de geïnterviewde verpleegkundigen aan dat interacties met collega's, leidinggevenden, patiënten en artsen eveneens invloed hebben uitgeoefend op wat men uit de bijscholing in de praktijk bracht. Tenslotte zouden ook organisatorische factoren, zoals het feit dat de bijscholing niet vertaald was in afdelingsbeleid, invloed hebben gehad op het gebruik van de bijscholing.

Tenslotte wordt in een algemeen beschouwend hoofdstuk ingegaan op methodologische kenmerken van respectievelijk het behoeftenonderzoek, de 'pilot study', de grootschalige interventiestudie en de kwalitatieve evaluatie-interviews. Tevens wordt stilgestaan bij de belangrijkste resultaten uit de verschillende studies. De hoofdconclusie is dat de pijnbijscholing een gunstige, maar vrij beperkte, uitwerking heeft gehad op verpleegkundigen en patiënten. Dit laatste hoofdstuk besluit met aanbevelingen voor de verpleegkundige praktijk, onderwijs en onderzoek. 
DANKWOORD 


\section{DANKWOORD}

"Toen ik den volgenden dag dit alles overzag, vroeg ik mij verwonderd af: is het wár dat gij dit alles hebt gedaan? Toen viel mijn oog op het schilderij dat mij was geschonken, de afbeelding van mijn ouderlijk huis met de kamer waarin ik als meisje had gestudeerd en had zitten peinzen over de onzekere toekomst. Was het werkelijk waar, dat alles wat ik had doorleefd, - en nog veel meer wat in dit boek geen plaats kan vinden - zich had afgespeeld?" (Aletta Jacobs, 1924)

Het schrijven van een dankwoord is altijd een moment van reflectie. Hoe kon aan dit karwei een goed einde komen? Is dit slechts te danken aan eigen doorzettingsvermogen, energie, tijd en intelligentie (in volgorde van belangrijkheid)?

In het geval van dit proefschrift is het duidelijk dat de inzet van een groot aantal mensen uit mijn professionele en privé-omgeving onontbeerlijk is geweest. Daarom eerst een woord van dank voor de betrokken verpleegkundigen, managers en patiënten uit het Beatrix Ziekenhuis in Gorinchem, het Bronovoziekenhuis in Den Haag, het Sint Clara Ziekenhuis in Rotterdam, het Diakonessenhuis en het Ziekenhuis Oudenrijn in Utrecht. Zonder hen was dit proefschrift nooit tot stand gekomen. Ik waardeer het zeer dat men ondanks drukke of moeilijke omstandigheden toch tijd en aandacht aan mijn onderzoek wilde geven.

Mijn promotoren, Marco de Vries, Huda Huijer Abu-Saad en Mieke Grypdonck wil ik eveneens bedanken. Marco, je had zeker bij de opzet van dit onderzoek een inspirerende invloed. Je non-conformisme, creativiteit en warme aandacht voor patienten en hulpverleners zijn voor mij een voorbeeld. Huda en Mieke, jullie adviezen en steun zijn ook heel belangrijk geweest. Wat ons sterk bindt is onze betrokkenheid bij de verpleegkundige praktijk en onderzoek op dat gebied. Ik hoop dat deze betrokkenheid, ondanks de vaak wat afstandelijke benadering die inherent is aan een proefschrift, tussen de regels doorklinkt.

Bert Garssen, mijn co-promotor, wil ik danken voor zijn bruikbare commentaar gedurende het promotie-onderzoek. De andere (ex-)collega's van het Helen Dowling Instituut wil ik danken voor hun vriendschap en medeleven. Eén van hen wil ik met name noemen: Cock Kuipers voorzag mij iedere ochtend van de sportkrant en de laatste nieuwtjes.

Dank gaat ook uit naar de leden van de beoordelingscommissie voor het kritisch lezen van het proefschrift.

Till Erkens en Joop de Kler zijn mijn paranymphen èn de docenten die de pijnbijscholing hebben verzorgd. I $k$ besef dat onze samenwerking uniek was. Vaak hadden we aan een half woord genoeg om te kunnen begrijpen wat de ander bedoelde. Bij de ontwikkeling en organisatie van de bijscholing was dat heel belangrijk. Ik hoop dat de vriendschap die tussen ons ontstaan is, zich voortzet buiten de context van dit onderzoek.

Bart Luiken en Andrea de Schepper verdienen speciale aandacht. Jullie inzet eerst als stagiaire, later als co-onderzoeker - was enorm. Nooit was jullie iets te veel en vaak dacht ik dat jullie nog meer overhadden voor het onderzoek dan ik zelf. Ik heb het gewaardeerd dat jullie me op zware momenten vaak een hart onder de riem staken. Vera Reijns, Audrey Lemmens, Iris Theeuwen, Suzanne Arts en Angelique van Straalen hebben als assistente of stagiaire bijdragen aan mijn onderzoek geleverd. Ook hun inzet 
was groot.

Hugo Duivenvoorden, adviserend methodoloog/statisticus, heeft mij op zeer vee! momenten bijgestaan. Hugo, hartelijk dank daarvoor.

Pieter Borg. Wout Dingemans, Rianne de Wit, R.B. Alting van Geusau en G. Hekster en vele, niet men name genoemde anderen hebben mij van advies gediend op cruciale momenten in het onderzoek. Ook naar hen gaat mijn dank uit.

Edith Schreuder, Joseph Wiggins en Sam Pasiencier wil ik danken voor hun taalkundige ondersteuning.

De belangstelling en steun van mijn moeder, overige familie, vrienden en vriendinnen waren onmisbaar. En 'last, but not least', heeft Erik mij door zijn liefde en door wie hij is, altijd laten merken dat er nòg belangrijker zaken zijn in het leven dan een prnefschrift. We gaan nu een nieuwe periode van ons leven in: het proefschrift is af! 
CURRICULUM VITAE 


\section{CURRICULUM VITAE}

Anneke Francke werd geboren op 30 juni 1959 te Oostkapelle. Na het Hoger Algemeen Voortgezet Onderwijs volgde zij in het Gasthuis te Middelburg een opleiding tot verpleegkundige A (1977-1981). Een half jaar na haar diplomering ging ze naar de Sociale Academie in Kampen. Na het basisjaar (1981) besloot zij haar studiepad te vervolgen aan de Rijks Universiteit Utrecht met een studie Westerse Sociologie (19821987). Tijdens haar sociologiestudie werkte Anneke in diverse gezondheidszorginstellingen in de regio Utrecht.

In de periode 1988-1995 was Anneke als onderzoekster werkzaam in het Helen Dowling Instituut voor Biopsychosociale Geneeskunde in Rotterdam. In de eerste jaren verrichtte zij verkennende, merendeels kwalitatieve studies die zouden resulteren in de ontwikkeling van een pijnbijscholing voor verpleegkundigen. In de latere jaren was zij gericht op de voornamelijk kwantitatieve evaluatie van de effecten van de pijnbijscholing. Deze onderzoekswerkzaamheden vonden hun neerslag in dit proefschrift.

Vanaf december 1995 werkt zij in het Nederlands Instituut voor Onderzoek van de Gezondheidszorg (NIVEL). Zij verricht daar onderzoek op het gebied van transmurale verpleegkundige zorg. Daarnaast is Anneke vanaf 1994 betrokken bij de projectorganisatie Verplegingswetenschap in Utrecht. $\mathrm{Zij}$ is daar coördinator van de onderwijsmodule 'Onderzoek van Zorg'.

Publikaties van haar hand zijn onder meer: 'Kwalitatief onderzoek in de verpleegkunde' (1990, redactie), 'Pijn als verpleegprobleem' (1992), 'Verplegen, interveniëren en evalueren' (1993, redactie) en 'Kwalitatief evaluatie-onderzoek' (1994, redactie samen met $\mathbf{R}$. Richardson).

Anneke Francke was born on June 30, 1959 at Oostkapelle, the Netherlands. After completing highschool she enrolled at the Gasthuis in Middelburg (1977-1981) where she studied for a Nursing A diploma. Six months after successfully completing her studies she continued her education at the Social Academy in Kampen. At the end of the first year there, she decided to transfer to the University of Utrecht in order to follow a program in Western Sociology (1982-1987). Anneke worked at various health institutions in the Utrecht area during her sociology studies.

Anneke worked as a researcher at the Helen Dowling Institute for Biopsychosocial Medicine in Rotterdam. During her first years there she conducted exploratory, mostly qualitative, studies aimed at developing a continuing pain education program for nurses. In later years she continued her research with primarily quantitative evaluation of the effects of the aforementioned program. This dissertation represents her research work.

She has been working at the Netherlands Institute of Primary Health Care (NIVEL) since december 1995, where she conducts research in the area of liaison nursing. In addition, Anneke has been involved with the department of Nursing Science, University of Utrecht. She is coordinator of the education module 'Care Research'.

Her publications include 'Kwalitatief onderzoek in de verpleegkunde' ('Qualitative research in nursing', 1990 editorial), 'Pijn als een verpleegprobleem' ('Pain as a nursing problem', 1992), 'Verplegen, interveniëren en evalueren' (Nursing, intervention and evaluation', 1993 editorial) and 'Kwalitatief evaluatie-onderzoek' ('Qualitative evaluation research', 1994, edited with $\mathrm{R}$. Richardson). 
APPENDIX I 


\section{DESCRIPTION OF THE CONTENT OF THE PROGRAM}

\section{Main program items:}

$\begin{array}{ll}\text { a/ } & \text { PAIN AND THE ASSESSMENT OF PAIN, } \\ \text { b/ } & \text { PSYCHOSOCLAL INTERVENTIONS, } \\ \text { c/ } & \text { PHYSICAL AND RELAXATION INTERVENTIONS, } \\ \text { d/ } & \text { PHARMACOLOGICAL PAIN MANAGEMENT. }\end{array}$

The themes discussed in the program are displayed below. The connection berween the program themes and the aforementioned items is clarified by means of the indicators $*, v, v$ ar $w$.

\begin{tabular}{|c|c|}
\hline Sessions & Themes \\
\hline 1 & $\begin{array}{l}\text { - What is pain? } \\
\text { - Nursing interventions in patients with pain bes } \\
\text { - Promotion of patients' autonomy }\end{array}$ \\
\hline 2 & $\begin{array}{l}\text { - Sorts and aspects of pain }{ }^{\prime} \\
\text { - Pain histories and pain intensity ratings' }\end{array}$ \\
\hline 3 & $\begin{array}{l}\text { - Why are nurses important in pain assessment and management? } \\
\text { - Use of cold and heart }\end{array}$ \\
\hline 4 & $\begin{array}{l}\text { - Emotional support of patients with pain: content and process" } \\
\text { - Breath and muscle relaxation exercises" }\end{array}$ \\
\hline 5 & $\begin{array}{l}\text { - Pharmacological pain management } \\
\text { - Provision of information } \\
\star\end{array}$ \\
\hline 6 & $\begin{array}{l}\text { - Identifying with patients in pain } \\
\text { - Video-presentation about a patient who has undergone a mastectomy } y^{b}\end{array}$ \\
\hline 7 & $\begin{array}{l}\text { - Care and cure in patients with pain } \\
\text { - Distraction and relaxation exercises } \\
\text { - Massage }\end{array}$ \\
\hline 8 & $\begin{array}{l}\text { - Comfort measures in patients with pain } \\
\text { - Working together in the interest of patients with pain }\end{array}$ \\
\hline
\end{tabular}

Instructors and participants: the program is taught by two instructors and is directed to qualified nurses involved in direct patient care activities.

Educational method: the method used is Confluen Education (see Chapter 4 of the disserution). characterized by a student-directed approach in which parcicipants partially determine the program content and process. In connection with this method, the written program presented in the following pages is not an unalterable fact, but rather serves as a guideline. The general content and methods are decided in advance. Nevertheless. the participants play a significant role in elaborating it: they are invited to indicate their leaming needs in each session, and the program activities are attuned to their indications.

Duration and structure: each session lasts three hours, with a break of about rwenty minutes halfway through. The exact time spent on a particular theme - within the time limits of the session - depends parially on the group's reactions and questions.

Locarion: the program is held in a room at the hrospital where the parricipants work. 


\section{Homework literature}

The participants receive a file contuining all homework literature at the first session. Home work assignments are given at the end of each session.

\begin{tabular}{l|l} 
Session & Literature: \\
\hline 1 & $\begin{array}{l}\text { Francke, AL (1992). Page 7-17 from Pijin als } \\
\text { verpleegnrobleem (Pain as a nursing problem). }\end{array}$ \\
$\begin{array}{l}\text { Dwingeloo: Kavanah. } \\
2\end{array}$ & $\begin{array}{l}\text { Sanwel, H (1992). De cultuur van de pijn (The culture of } \\
\text { pain). In Unnublished conpressbook. Gorinchem: Beatrix } \\
\text { Ziekenhuis. }\end{array}$
\end{tabular}

Asonymus (1986). 'Gewoon een mammaprocedure', het relaas van een vrouw die patien werd en wat dat voor haar betekende ('Only a breast operation', the experiences of a woman who became a patient). Medisch Contact. $663-667$.

3 Wit, R de \& Van Dam, FSAM (1991). Verpleegkundige pijnmeting bij kankerpatiënten: een interventiestudie (Nursing pain measurement in cancer patients: an intervention study). Verpleegkunde. Nederlands-Vlaams Wetenschappelijk Tijdschrift voor Verpleegkundigen 6,2 , 68-75.

Schulkes-Van der Pol, J (Ed. 1990). Page 14-21 from Piin en pijnbehandeling hii de patient met kanker (Pain and pain management in the patient with cancer). Amsterdam: Nederlandse Vereniging ter Bestudering van Pijn. veroleegrobleem (Pain as a nursing problem). Dwingeloo: Kavanah. Pijn en pijnbehandeling bij de patiènt met kanker (Pain and pain management in the patient with cancer). Amsterdam: Nederlandse Vereniging ter Bestudering van Pijn.

Francke, AL (1992). Page 28 from Pijn als verplecgprobleem (Pain as a nursing problem). Dwingeloo: Kavanah.

Erkens, MJM (1984). Hel ziekteproces yan Jos (Jos's sickness process). Unpublished thesis (nursing teacher progran. first grade). Maastricht: University of Limburg.

Theeuwen, I \& Francke, AL (1992). Geremdheid in het uiten van pijn (Inhibition in expressing pain).

Verplecgkunde. Nederlands-Vlaams Wetenschapoeliik Tiidschrift voor Veroleegkundigen, 1992/93, 2. 75-84. 
Session 1: - What is pain?

- Nursing interventions in patients with pain

- Promotion of patients' autonomy

\begin{tabular}{|c|c|c|c|}
\hline Learaing need & Porpase & Action & Evaluwtion \\
\hline $\begin{array}{l}\text { Instructors and } \\
\text { participants have } \\
\text { need to become } \\
\text { acquainted } \\
\text { with each other and } \\
\text { with the program. }\end{array}$ & $\begin{array}{l}\text { Instructors and participants } \\
\text { tave become acquainted, and } \\
\text { the participants are 'ready' to } \\
\text { go deeper into the program } \\
\text { themes. }\end{array}$ & $\begin{array}{l}\text { Group conversation and introduction. Participants } \\
\text { and instructors introduce themselves. Instructors } \\
\text { explain the program purposes, themes and the } \\
\text { research on the program. (total } \pm 30 \text { minules) }\end{array}$ & $\begin{array}{l}\text { Not } \\
\text { applicable. }\end{array}$ \\
\hline $\begin{array}{l}\text { Instructors want more } \\
\text { insight into } \\
\text { paricipants' } \\
\text { leaming needs with } \\
\text { respeci to pain } \\
\text { assessment and } \\
\text { managernent. }\end{array}$ & $\begin{array}{l}\text { Instructors have acquired this } \\
\text { insighd (see problem). } \\
\text { Participanis bve received at } \\
\text { impression as to how their } \\
\text { learning needs and wishes will } \\
\text { be incorporated in the program. }\end{array}$ & $\begin{array}{l}\text { Written assignment: } \\
\text { Why did you choose this program? What } \\
\text { do you want to leam//o, and, what not? } \\
\text { Followed by group discussion (total } \pm 20 \text { minutes) }\end{array}$ & $\begin{array}{l}\text { During } \\
\text { group } \\
\text { discussion. }\end{array}$ \\
\hline $\begin{array}{l}\text { Paricipants ward } \\
\text { more insight into the } \\
\text { phenomenon of pain. }\end{array}$ & $\begin{array}{l}\text { Participants are aware that pain } \\
\text { is a subjective feeling. and that } \\
\text { therefore the patient is the main } \\
\text { source of information about } \\
\text { pain. }\end{array}$ & 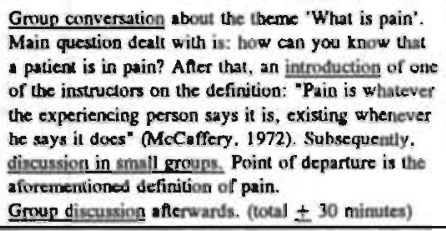 & $\begin{array}{l}\text { During } \\
\text { group } \\
\text { discussion. }\end{array}$ \\
\hline \multicolumn{4}{|c|}{ BREAK (10ul \pm 20 minutes) } \\
\hline $\begin{array}{l}\text { Participants seek more } \\
\text { knowledge of which } \\
\text { pain interventions } \\
\text { belong to the mursing } \\
\text { domain. }\end{array}$ & $\begin{array}{l}\text { Participanks are aware that } \\
\text { there are various pain } \\
\text { interventions in addition to the } \\
\text { pharmacological. In this } \\
\text { context, they can name the } \\
\text { possible effects of psychosocial, } \\
\text { physical and relaxation } \\
\text { interventions. }\end{array}$ & 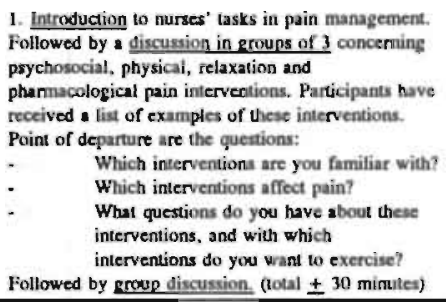 & $\begin{array}{l}\text { Daring } \\
\text { group } \\
\text { Jiscussion. }\end{array}$ \\
\hline $\begin{array}{l}\text { Participants want } \\
\text { more insight into } \\
\text { nursing interventions } \\
\text { for patients in pain, in } \\
\text { this case. promoting } \\
\text { patient's autonomy. }\end{array}$ & $\begin{array}{l}\text { Participants have oblained this } \\
\text { insight (see problem). }\end{array}$ & $\begin{array}{l}\text { Grrap discussion about promoting patients' } \\
\text { autonomy: } \\
\text { What are your ideas about this } \\
\text { inservention? } \\
\text { What do you know/wish to know about is? } \\
\text { Can you give examples of how. when and } \\
\text { bo whom this intervention applies? } \\
\text { Does this interiention alleviate pain? } \\
\text { - }\end{array}$ & $\begin{array}{l}\text { End of this } \\
\text { session. }\end{array}$ \\
\hline $\begin{array}{l}\text { Instructors and } \\
\text { participants have a } \\
\text { ficed to share leaming } \\
\text { experienoes and plans } \\
\text { for the next week. In } \\
\text { addition, instructors } \\
\text { want to receive } \\
\text { feedbact from } \\
\text { participante. }\end{array}$ & $\begin{array}{l}\text { Perticipants and instructors } \\
\text { have acquired insigra into } \\
\text { learning experiences and } \\
\text { remaining leaming needs. In } \\
\text { addition. a connection is mase } \\
\text { betwoen the program and } \\
\text { everyday life and work. }\end{array}$ & 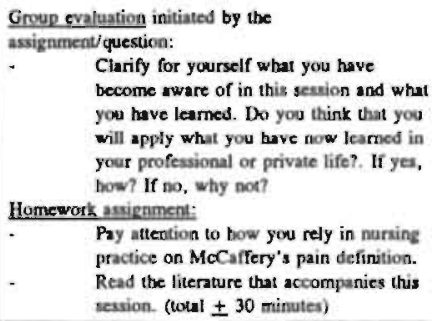 & $\begin{array}{l}\text { Not. } \\
\text { upplicable. }\end{array}$ \\
\hline
\end{tabular}


Session 2: $\quad$ - Sorts and aspects of pain

- Pain histories and pain intensity ratings

\begin{tabular}{|c|c|c|c|}
\hline I.cearaing need & Purpase & Action & Evaluation \\
\hline $\begin{array}{l}\text { Participants want to hear } \\
\text { fronn each other what they } \\
\text { brought into practice as a } \\
\text { result of the Last session. }\end{array}$ & $\begin{array}{l}\text { The learning atmosphere is } \\
\text { tesumed and the participanis } \\
\text { are ready to go deeper into } \\
\text { this session's themes. }\end{array}$ & $\begin{array}{l}\text { Opening rund: } \\
\text { How do you look tack on the lase session? } \\
\text { - How did it go with the homework assignment? } \\
\text { - Were you able to apply the material leasned in } \\
\text { practice? } \\
\text { - Was the reading assignment usefur? } \\
\text { - Do yow have wishes or questions for today? } \\
\text { (total } \pm 30 \text { min.) }\end{array}$ & $\begin{array}{l}\text { Not } \\
\text { upplicable. }\end{array}$ \\
\hline $\begin{array}{l}\text { Participants want more } \\
\text { insight into the } \\
\text { phenomenon of pain and } \\
\text { the various sorts of pain. }\end{array}$ & $\begin{array}{l}\text { Participants know what is } \\
\text { meant by physical, } \\
\text { emotionail, mental and } \\
\text { existential pain. In addition. } \\
\text { they an reegrize these } \\
\text { sons of pain in the patients } \\
\text { under theit care. }\end{array}$ & $\begin{array}{l}\text { During a group discussion an inventory is made of } \\
\text { what sorts of pain pacients may have. The instructors } \\
\text { categorize the various pains in: physical, emotional, } \\
\text { mental and existential pain. They stress that there are } \\
\text { differences, but no clear division between these pains. } \\
\text { (tossl } \pm 40 \text { minutes) }\end{array}$ & $\begin{array}{l}\text { End of this } \\
\text { session. }\end{array}$ \\
\hline \multicolumn{4}{|c|}{ BREAK $( \pm 20$ minutes) } \\
\hline $\begin{array}{l}\text { Participants want more } \\
\text { insight into what is } \\
\text { involved } \\
\text { in taking a pain history and } \\
\text { pain intensity ratings. }\end{array}$ & $\begin{array}{l}\text { Participants hive received } \\
\text { an impression of how to } \\
\text { carry out the taking of a } \\
\text { pain listory and paits } \\
\text { intensity ratings. Hereby, } \\
\text { they glave considered } \\
\text { whether (and if yes. } \\
\text { how) they will integrate } \\
\text { these procedures in their } \\
\text { ow'l practice. }\end{array}$ & 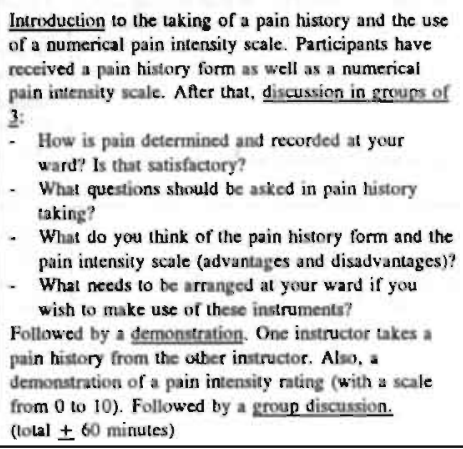 & $\begin{array}{l}\text { During } \\
\text { group } \\
\text { discussion. }\end{array}$ \\
\hline $\begin{array}{l}\text { See session I group } \\
\text { evaluation. }\end{array}$ & $\begin{array}{l}\text { See session I yruap } \\
\text { evaluation }\end{array}$ & $\begin{array}{l}\text { Group evaluation: see session } 1 \\
\text { Honework assignment } \\
\text { - Use the numerical pain intensity scale in practice. } \\
\text { - Be aware of what sonts of pain you encounter in } \\
\text { patients during the next week. and how you handle } \\
\text { it. } \\
\text { - Read the literature that accompanies this session. } \\
\text { (tolal } \pm 30 \text { mitules) }\end{array}$ & $\begin{array}{l}\text { Not } \\
\text { applicable. }\end{array}$ \\
\hline
\end{tabular}




\begin{tabular}{|c|c|c|c|}
\hline Learning need & Purpase & 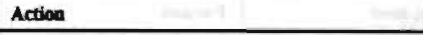 & Evahustion \\
\hline See session 2 opening round. & See session 2 opening round. & $\begin{array}{l}\text { Sec seasion } 2 \text { openine round. } \\
\text { (in toul } \pm 30 \text { minutes) }\end{array}$ & $\begin{array}{l}\text { Not } \\
\text { applicable. }\end{array}$ \\
\hline $\begin{array}{l}\text { Participants wand more } \\
\text { insight into their tasks in the } \\
\text { area of pain assetsment and } \\
\text { management. }\end{array}$ & $\begin{array}{l}\text { Participants have acquired } \\
\text { this insight (sce problem). } \\
\text { Aso, they are more awart of } \\
\text { their central role in } \\
\text { interdisciplinary } \\
\text { pain mamagement. }\end{array}$ & 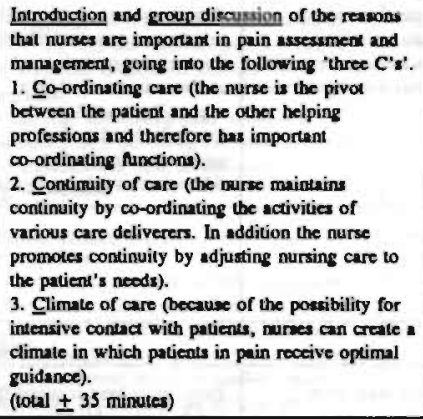 & $\begin{array}{l}\text { During: } \\
\text { group } \\
\text { discussion. }\end{array}$ \\
\hline $\begin{array}{l}\text { Participants want more inxight } \\
\text { into what pain means for } \\
\text { patieats. }\end{array}$ & $\begin{array}{l}\text { Participants sre aware that } \\
\text { every person's pain is unique, } \\
\text { and they also know what stills } \\
\text { and atcides are needed to care } \\
\text { for each patieat appropriately. }\end{array}$ & 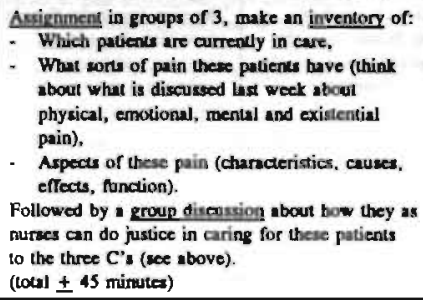 & $\begin{array}{l}\text { During! } \\
\text { group } \\
\text { discussion. }\end{array}$ \\
\hline \multicolumn{4}{|c|}{ BREAK ( \pm 20 minutes) } \\
\hline $\begin{array}{l}\text { Participants want more insight } \\
\text { into nursing pain interventions, } \\
\text { in this case, the use of heal and } \\
\text { cold. }\end{array}$ & $\begin{array}{l}\text { Participants have acquired this } \\
\text { insight (see problem) }\end{array}$ & 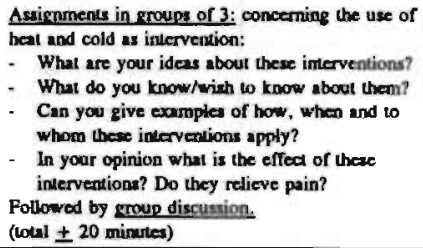 & $\begin{array}{l}\text { During } \\
\text { group } \\
\text { điscussion. }\end{array}$ \\
\hline Soc seasion 1 group evaluation. & Sec session 1 group evaluation. & 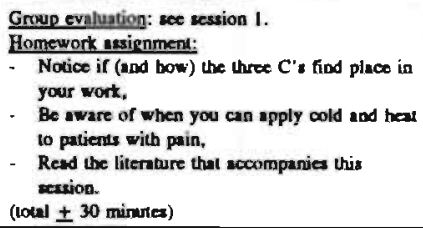 & $\begin{array}{l}\text { Not } \\
\text { applicable. }\end{array}$ \\
\hline
\end{tabular}




\begin{tabular}{|c|c|c|c|}
\hline Learning need & Purpose & Action & Erahuation \\
\hline $\begin{array}{l}\text { See session } 2 \text { opening } \\
\text { round. }\end{array}$ & See session 2 opening rousid. & $\begin{array}{l}\text { See session } 2 \text { openiny round. } \\
\text { (in totai } \pm 30 \text { minutes) }\end{array}$ & Not applicable. \\
\hline $\begin{array}{l}\text { Farticipants desiire more } \\
\text { insight into nursing } \\
\text { interventions in patients with } \\
\text { pain. in this caste, emotional } \\
\text { suppore. }\end{array}$ & $\begin{array}{l}\text { Participants trave acquired this } \\
\text { insight (see problem). Hereby } \\
\text { they understand that } \\
\text { sometimes patients, do not } \\
\text { expeca direct solutions } \\
\text { (content), but that they do } \\
\text { appreciate suppont from a } \\
\text { fellow human being (process). }\end{array}$ & 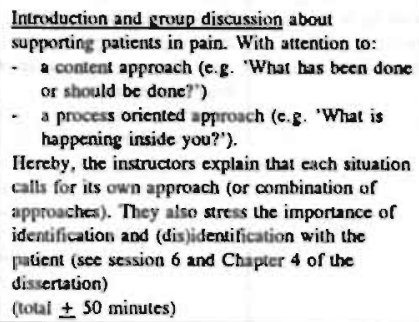 & $\begin{array}{l}\text { End of this } \\
\text { sesxion. }\end{array}$ \\
\hline \multicolumn{4}{|c|}{ BREAK $( \pm 20$ minutes) } \\
\hline $\begin{array}{l}\text { Paricipants want more } \\
\text { inaight into mursing } \\
\text { interventions for palienss } \\
\text { with pain. In this case, the } \\
\text { use of breathing and muscle } \\
\text { islaxalion technigues. }\end{array}$ & $\begin{array}{l}\text { Paricipants have acquired this } \\
\text { insigbe (see problem). } \\
\text { Thereby, they have thought } \\
\text { about, how they can use } \\
\text { breathing and muscle } \\
\text { relaxation techniques in } \\
\text { nursing practice. }\end{array}$ & 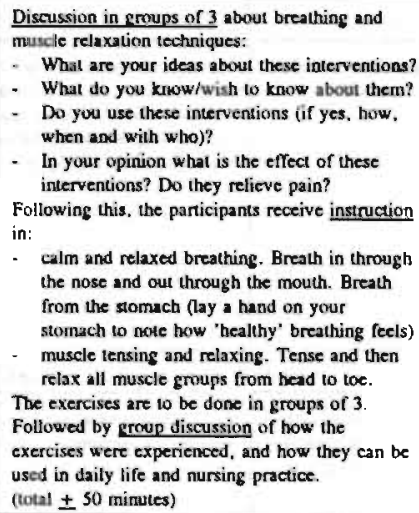 & $\begin{array}{l}\text { Doring group } \\
\text { discustion. }\end{array}$ \\
\hline $\begin{array}{l}\text { Paricipants and instructors } \\
\text { wish to know the general } \\
\text { experience of the program } \\
\text { up to this point, and what } \\
\text { are the leaming needs for } \\
\text { the coming sessions. }\end{array}$ & $\begin{array}{l}\text { Participants and instructors } \\
\text { know the general opinion } \\
\text { about the program. } \\
\text { Participants have accepted } \\
\text { their responsibility for making } \\
\text { the second half of the program } \\
\text { is success. }\end{array}$ & $\begin{array}{l}\text { Interim eroun evaluation based on the following } \\
\text { questions: } \\
\text { - what have you gained so far from the } \\
\text { program? } \\
\text { - what have you missed? } \\
\text { - what do you anticipate from the coming } \\
\text { sessions? } \\
\text { IIrmewoit ascignment: } \\
\text { - be aware of contem and process in talking to } \\
\text { patients, } \\
\text { - practice 'healthy' breathing, and } \\
\text { tensing/retaxing (privately or with patients). } \\
\text { read the titerature accompanying this session. } \\
\text { (tots } \pm 30 \text { minules) }\end{array}$ & Nos applieable. \\
\hline
\end{tabular}


Session 5: $\quad$ - Phannacological pain manugement

- Provision of intomation

\begin{tabular}{|c|c|c|c|}
\hline Leaming aced & Purpose & $\sqrt{1}$ & Evahuation \\
\hline $\begin{array}{l}\text { See ression } 2 \text { opening } \\
\text { round. }\end{array}$ & $\begin{array}{l}\text { Sec session } 2 \text { opening } \\
\text { round. }\end{array}$ & $\begin{array}{l}\text { See seasion } 2 \text { opening round. } \\
\text { (in total } \pm 30 \text { minestes) }\end{array}$ & $\begin{array}{l}\text { Not } \\
\text { applicable. }\end{array}$ \\
\hline $\begin{array}{l}\text { Participants want more } \\
\text { insight into which are } \\
\text { nursing tasks in } \\
\text { pharmacological pain } \\
\text { management, and which } \\
\text { usks belong to other } \\
\text { disciplines. }\end{array}$ & $\begin{array}{l}\text { Participants can mame their } \\
\text { own and other care } \\
\text { providers' asks in the area } \\
\text { of phamacological pain } \\
\text { managenen. }\end{array}$ & $\begin{array}{l}\text { Group discussion about pharmmcological tusks of: } \\
\text { nurses (e.g. administintion of pain modication, } \\
\text { and informing the patients about the use of } \\
\text { amalgesics). } \\
\text { - doctors (e.g. prestribing pain medication) } \\
\text { - pharmacists (e.g. providing information about } \\
\text { pain modication to other disciplines). } \\
\text { (total } \pm 30 \text { minutes) }\end{array}$ & $\begin{array}{l}\text { End of this } \\
\text { session. }\end{array}$ \\
\hline $\begin{array}{l}\text { Participants want to expand } \\
\text { their knowledge of } \\
\text { pharmacological pain } \\
\text { management. }\end{array}$ & $\begin{array}{l}\text { Participants have increased } \\
\text { their knowledge (e.g. } \\
\text { aboul effects/side-effects } \\
\text { of pain medication, the } \\
\text { rationale of scheduled } \\
\text { amalgesics, and the } \\
\text { function of an } \\
\text { interdisciplinary pain } \\
\text { team). }\end{array}$ & 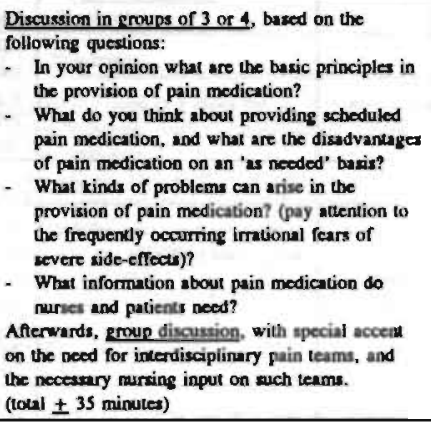 & $\begin{array}{l}\text { During } \\
\text { group } \\
\text { discukcion. }\end{array}$ \\
\hline \multicolumn{4}{|c|}{ BREAK $( \pm 20$ minutes $)$} \\
\hline $\begin{array}{l}\text { Participants want mare } \\
\text { insight inso mursing } \\
\text { imfervertions, in this } \\
\text { case, the providing of } \\
\text { information. }\end{array}$ & $\begin{array}{l}\text { Paricipants have acquired } \\
\text { this insight (we problem). }\end{array}$ & $\begin{array}{l}\text { Group discussion conceming providing patient- } \\
\text { orieated infommation, based on the following } \\
\text { guestions: } \\
\text { - What are your ideas about this intervention? } \\
\text { - What do you know/wish to know about it? } \\
\text { - Can you give examples of bow, when and to } \\
\text { whom this intervention applies? } \\
\text { - In your opinion what is the effoct of this } \\
\text { intervention? Does it alleviate pain? } \\
\text { (total } \pm 35 \text { mixates) }\end{array}$ & $\begin{array}{l}\text { End of this } \\
\text { sastion. }\end{array}$ \\
\hline $\begin{array}{l}\text { Sec session } 1 \text { group } \\
\text { evatuation. }\end{array}$ & $\begin{array}{l}\text { Soc sctsion } 1 \text { group } \\
\text { evaluation. }\end{array}$ & 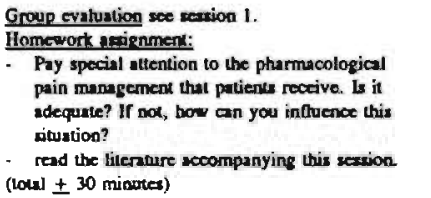 & $\begin{array}{l}\text { Nor } \\
\text { applicable. }\end{array}$ \\
\hline
\end{tabular}


Session 6: - IJentifying with pacients in pain

- Videa-presentation about a patient who has undergolic a masteclumy

\begin{tabular}{|c|c|c|c|}
\hline Learaing aced & Purpose & Action & Evaluation \\
\hline $\begin{array}{l}\text { See session } 2 \text { opening } \\
\text { round. }\end{array}$ & See session 2 opening round. & $\begin{array}{l}\text { See session } 2 \text { opening mund. } \\
\text { (in total } \pm 30 \text { minutes) }\end{array}$ & $\begin{array}{l}\text { Nor } \\
\text { applicable. }\end{array}$ \\
\hline $\begin{array}{l}\text { Participants wish co } \\
\text { acquire more insight into } \\
\text { how far one can go in } \\
\text { identifying with a patient } \\
\text { in pain. }\end{array}$ & $\begin{array}{l}\text { Participants know that it is } \\
\text { important to identify with the } \\
\text { patient io pain, but that it is } \\
\text { also important to release this } \\
\text { identificution afterwards. }\end{array}$ & $\begin{array}{l}\text { Groun conversation concerning identifying with patients } \\
\text { in pain: how does one do that, how tar do you go into } \\
\text { it? Followed by the following communication exercise: } \\
\text { - Form a group of 3: person A is a patient in pain, } \\
\text { person B is a nurse, person C is an observer. } \\
\text { Persons A and B talk about B's pain. Person C } \\
\text { observes: 1) how A experiences pain, 2) the } \\
\text { content and 'process' aspects of the conversation A } \\
\text { has with B. } \\
\text { Each person experiences the roles A, B and C. } \\
\text { Aflerwards discussion first in small groups. and then in } \\
\text { the total group. Hereby, instructors give further } \\
\text { explanation of the importance of identification and being } \\
\text { able to 'It go' this identification. } \\
\text { (total } \pm 40 \text { minutes) }\end{array}$ & $\begin{array}{l}\text { During } \\
\text { group } \\
\text { discussion. }\end{array}$ \\
\hline \multicolumn{4}{|c|}{ BREAK $( \pm 20$ minutes) } \\
\hline $\begin{array}{l}\text { Participants want to know } \\
\text { more about the } \\
\text { experiences of patients } \\
\text { with cancer and pain. }\end{array}$ & $\begin{array}{l}\text { Participants have acquired this } \\
\text { insight (see problem). }\end{array}$ & $\begin{array}{l}\text { Video presentation about a woman who had many } \\
\text { operations as a result of breast cancer. She talks atout } \\
\text { how it feels to have cancer, and to miss a breast, and } \\
\text { about her experiences with nurses and other care } \\
\text { providers. } \\
\text { Afterwards a group discussion to include attention to: } \\
\text { - general reactions to, and questions about the video. } \\
\text { - what sort of pain(s) did this woman suffer? } \\
\text { - how would you have supported this woman? } \\
\text { - how can you identify with this woman and then } \\
\text { 'let-go' this identification? } \\
\text { (total } \pm 20 \text { minutes) }\end{array}$ & $\begin{array}{l}\text { During } \\
\text { group } \\
\text { discussion. }\end{array}$ \\
\hline $\begin{array}{l}\text { See session I group } \\
\text { evaluation. }\end{array}$ & $\begin{array}{l}\text { See sestion I group } \\
\text { evaluation. }\end{array}$ & $\begin{array}{l}\text { Group evaluation: see session } 1 . \\
\text { Homework assianment: } \\
\text { - Try to practice identification and disidentification } \\
\text { with patients. Observe what you need to do in this } \\
\text { respect. } \\
\text { - Read the bicrature accompanying this session. } \\
\text { (todal } \pm 20 \text { minutes) }\end{array}$ & $\begin{array}{l}\text { Nor } \\
\text { applicable. }\end{array}$ \\
\hline
\end{tabular}


Session 7: $\quad$ - Care and cure in patiens with pain

- Distraction and relucation exercises

- Massage

\begin{tabular}{|c|c|c|c|}
\hline Learuing aced & Purpase & Action & Exalupton \\
\hline $\begin{array}{l}\text { Set seasion } 2 \text { opering } \\
\text { round. }\end{array}$ & $\begin{array}{l}\text { Sce session } 2 \text { opening } \\
\text { rouns. }\end{array}$ & $\begin{array}{l}\text { See session } 2 \text { opening round. } \\
\text { (in total } \pm 30 \text { minutes) }\end{array}$ & $\begin{array}{l}\text { Not } \\
\text { applicablic. }\end{array}$ \\
\hline $\begin{array}{l}\text { Participants wan to know } \\
\text { how to achieve a balance } \\
\text { between care and core in } \\
\text { patients with pain. }\end{array}$ & $\begin{array}{l}\text { Participanss have } \\
\text { acquired insight into } \\
\text { what they might possibly } \\
\text { change in attitudes or } \\
\text { practices to achieve } \\
\text { more balance between } \\
\text { care and cure. }\end{array}$ & 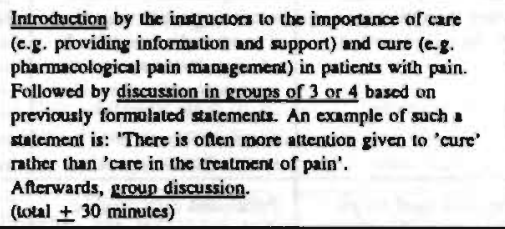 & $\begin{array}{l}\text { During } \\
\text { group } \\
\text { dicussion. }\end{array}$ \\
\hline \multicolumn{4}{|c|}{ BREAK $( \pm 20$ minutes) } \\
\hline $\begin{array}{l}\text { Participands want more } \\
\text { insight into nursing } \\
\text { interventions in patients } \\
\text { with pain. In this case., the } \\
\text { use of distraction and } \\
\text { relaxation techniques. }\end{array}$ & $\begin{array}{l}\text { Participarts have } \\
\text { acquired this insighe (soe } \\
\text { problem). }\end{array}$ & 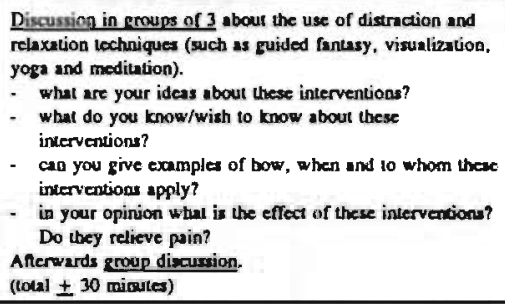 & $\begin{array}{l}\text { During } \\
\text { grows } \\
\text { discussion. }\end{array}$ \\
\hline $\begin{array}{l}\text { Participants want to } \\
\text { become more acquainted } \\
\text { with masage. }\end{array}$ & $\begin{array}{l}\text { Participants have thougt } \\
\text { about which forms of } \\
\text { massage they can apply } \\
\text { is nursing practice, and } \\
\text { possibly negative } \\
\text { axsociations with regard } \\
10 \text { mawage are } \\
\text { diminished. }\end{array}$ & 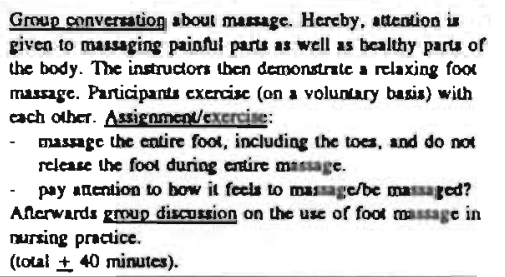 & $\begin{array}{l}\text { During } \\
\text { growp } \\
\text { divcussion. }\end{array}$ \\
\hline $\begin{array}{l}\text { See session } 1 \text { group } \\
\text { evaluation. }\end{array}$ & $\begin{array}{l}\text { Sec session } 1 \text { eroup } \\
\text { evalastion. }\end{array}$ & 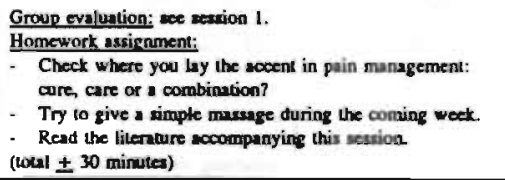 & $\begin{array}{l}\text { Not } \\
\text { upplicable. }\end{array}$ \\
\hline
\end{tabular}


Session 8: $\quad$ - Comfort measures in patients with pain

- Working together in the inferest of paticnts with puin

\begin{tabular}{|c|c|c|c|}
\hline Learning oced & Purpose & Action & Eraluation \\
\hline See session 2 opening round. & See session 2 opening round. & $\begin{array}{l}\text { See session } 2 \text { onenine round. } \\
\text { (iv total } \pm 30 \text { minutes) }\end{array}$ & $\begin{array}{l}\text { Not } \\
\text { applicable. }\end{array}$ \\
\hline $\begin{array}{l}\text { Participants want more insight } \\
\text { into how they can relieve pain in } \\
\text { patients by the use of comfort } \\
\text { measures. }\end{array}$ & $\begin{array}{l}\text { Participants are aware that } \\
\text { comfort measures may have } \\
\text { - positive efleet on pain. In } \\
\text { addition, they are aware that } \\
\text { these inierventions are often } \\
\text { simple to practice, and } \\
\text { therefore oflen do not } \\
\text { receive their proper value. }\end{array}$ & $\begin{array}{l}\text { Group discussion about everyday measures } \\
\text { focusing on the physical and environmental } \\
\text { comfor of patienis (e.g. promoting a } \\
\text { comfortable lying position and an agreeable bed } \\
\text { environment). The importance of these measures } \\
\text { to patients' pain is a central topic in the } \\
\text { discussion. } \\
\text { (tolal } \pm 20 \text { mirutes) }\end{array}$ & $\begin{array}{l}\text { End of this } \\
\text { session. }\end{array}$ \\
\hline $\begin{array}{l}\text { Participants want more insight } \\
\text { imo how to co-operate with } \\
\text { other care providers. Hereby, } \\
\text { they wanl to learn low to handle } \\
\text { differences of opinion. }\end{array}$ & $\begin{array}{l}\text { Paricipants have acquired } \\
\text { this insight (ser problem). } \\
\text { Hereby, they understand that } \\
\text { 'sharing their own pain' can } \\
\text { be important to maintain the } \\
\text { care of patients in pain. }\end{array}$ & $\begin{array}{l}\text { Discussion in eroups of } 3 \text { based on the following } \\
\text { questions: } \\
\text { - In your opinion, what constitutes good } \\
\text { co-operation/bad co-operation within the } \\
\text { framework of pain assessment and } \\
\text { management? } \\
\text { Can you call en each other when you find } \\
\text { your work difficult? What can colleagues do } \\
\text { for you? } \\
\text { Anerwards, groun discussion focusing on the } \\
\text { fact that co-operation is onen hindered by } \\
\text { projection of personal opinions, and a lack of } \\
\text { mutual consultation between care providers. } \\
\text { Hereby. instructors demonstrate so-called } \\
\text { 'gessalt-pietures' (pictures in which several } \\
\text { distinet images can te discovered). Suitable } \\
\text { questions are: } \\
\text { - How do you see what you see? } \\
\text { - What do you need to see it another way? } \\
\text { - Do you see the parallel with co-operation in } \\
\text { practice, where sometimes you receive an } \\
\text { eatirely differeat opinion from doctors. } \\
\text { colleagues or patients? } \\
\text { (total } \pm 60 \text { minutes) }\end{array}$ & $\begin{array}{l}\text { During group } \\
\text { discussion. }\end{array}$ \\
\hline \multicolumn{4}{|c|}{ BREAK ( \pm 20 minutes $)$} \\
\hline $\begin{array}{l}\text { Participants and instructors have } \\
\text { aneed to look back on the } \\
\text { program, and to any good-bye to } \\
\text { each odher in a careful way. }\end{array}$ & $\begin{array}{l}\text { Paricipants have though } \\
\text { over their experiences during } \\
\text { the program, what they have } \\
\text { learned and how they will } \\
\text { bring this into practice. } \\
\text { Participants urdersand that } \\
\text { evaluation and feed-back } \\
\text { provide a way to end } \\
\text { something wilhout, being lef } \\
\text { with 'pain'. }\end{array}$ & 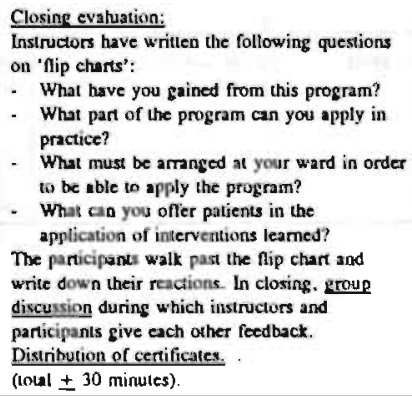 & $\begin{array}{l}\text { Not } \\
\text { applicable. }\end{array}$ \\
\hline
\end{tabular}


FOLLOW-UP SESSION (4 months after the end of the program)

Learning need: Participants want to share their experiences in applying the program in nursing practice. The instructor" wants to know whether the participants consider the program valuable several months after its end. In addition, she intends to determine what questions participants still bave concerning caring for patients with pain.

Objective: Participants feel that the gap between what they have learned in the program and nursing practice is further narrowed. The instructor has gained insight into which parts of the program need revision.

Action: The instructor visits the ward at a time arranged well in advance. The bead nurse or team leader has ensured that as many participants as possible are on duty at that time. First, a group discussion is held in which the participants tell the instructor what they do (not) use from the program. In response, the instructor provides feedback and advice. In the company of one or more participants, the instructor attends some patients (only if the participants feel there is a need for it).

1. Only the instructor with the nursing background is involved in the follow-up session. This is due to the fact that this session, even more than the program itself, is focused on practical aspects of nursing care. 


\section{(7)

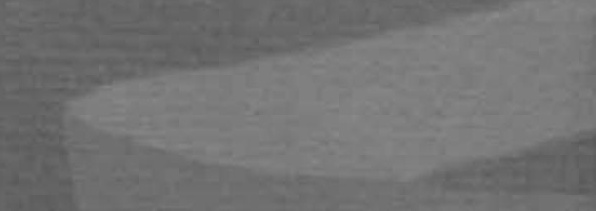

